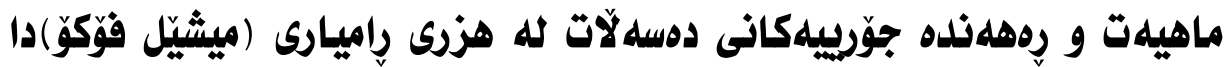

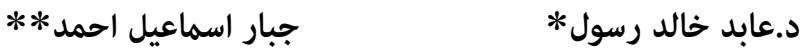

وشه كليليه كان: دهسلَات، هيّز، ديسيلبين، بايوّ دهسلَات، هزرى رِاميارى، ميّشيّل فوّكوّ. https://doi.org/10.31271/jopss.10022

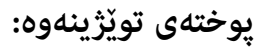

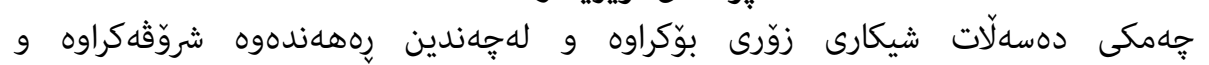

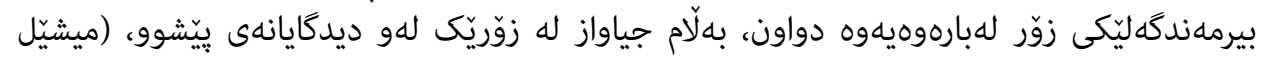

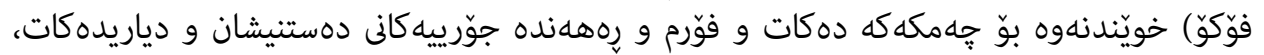

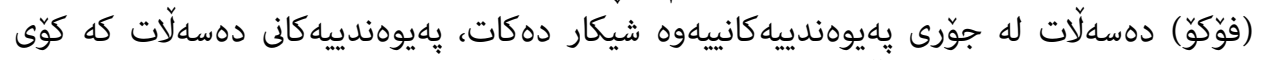

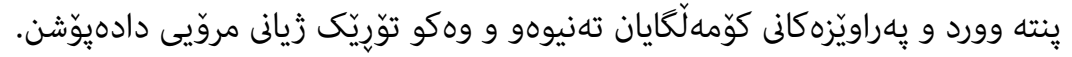

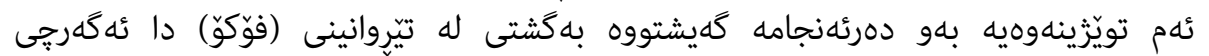

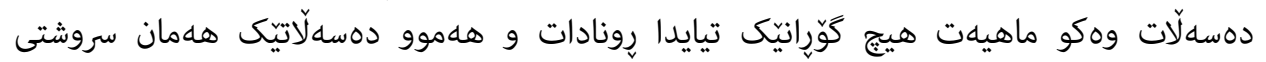

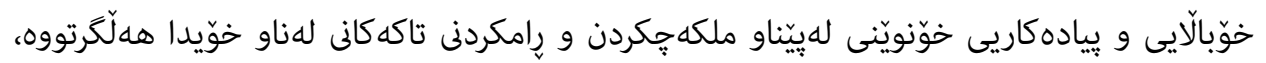

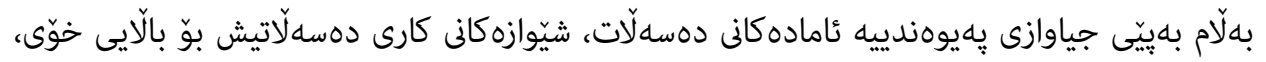

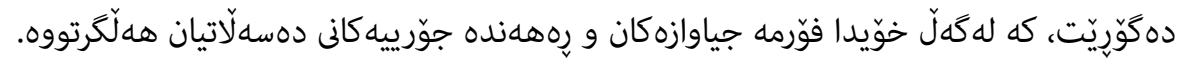

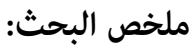

ماهية السلطة وأبعادها النوعية في الفكر السياسي لـ(ميشيل فوكو)

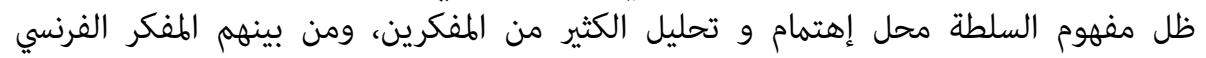

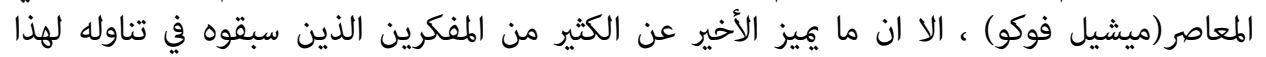

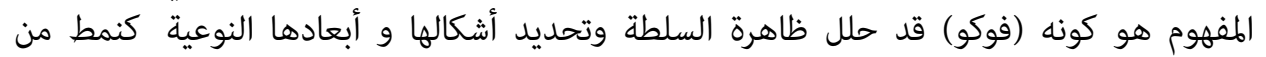

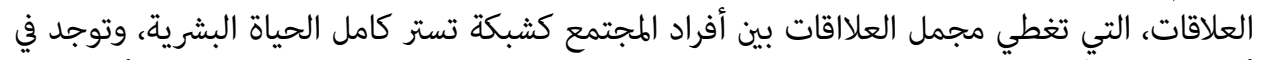

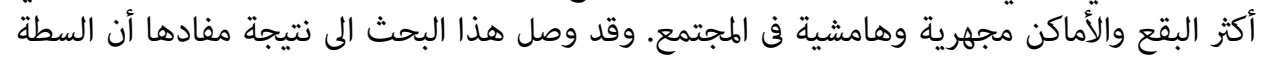

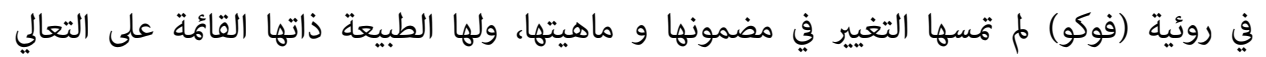

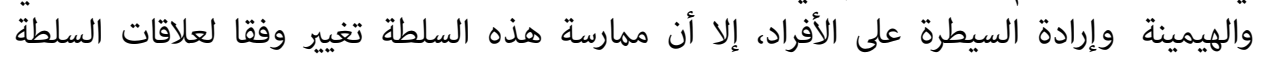

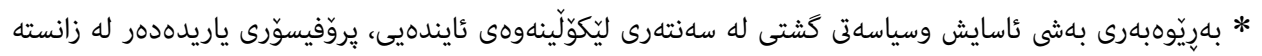
abid.rasul@univsul.edu.iq

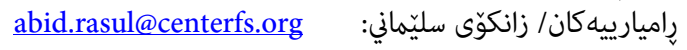
jabar.ahmed84@gmail.com ** خويندكارى ماستهر له كوّليجى زانسته رِاميارييه كان/ زانكوّى سليّمانى 
السائدة في المجتمع، مما تتغير معها ألأبعاد النوعية للسلطة، كم تتغير معها آليات تأثيرها أيضا.

\section{Abstract \\ The Essence of Power and its Forms in the Political Thought of (Michel Foucault)}

The term of power has been explained and analyzed in many ways and sides, it has been spoken about by several intellectuals. But differ from many of the previous ones, (Michel Foucault) analysis the term and indicates its forms and perceptions. (Foucault) analysis the power in its own connections whose cover all the tiny corners and forgotten edges in the community that are extending over all the humans life.

This research has been concluded that, in general Michel Foucault's point of view, besides being selfish and practicing its selfishness in its own nature so as to capitulate and govern the community members, power's working strategies are changing according to its available connection types and forms, those are holding different typical directions. 


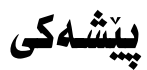

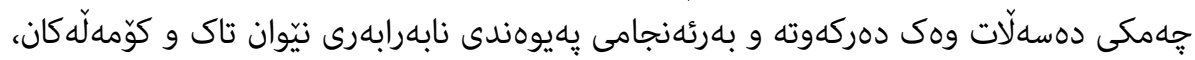

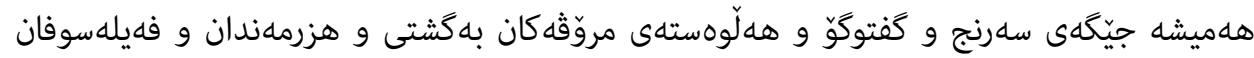

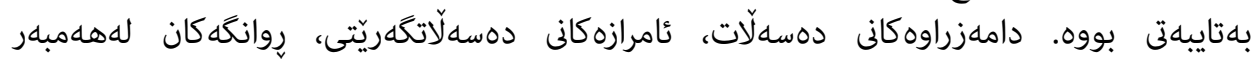

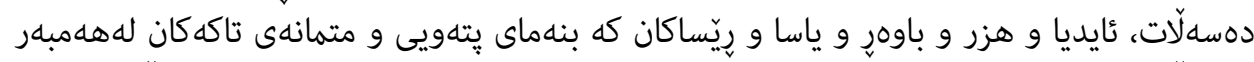

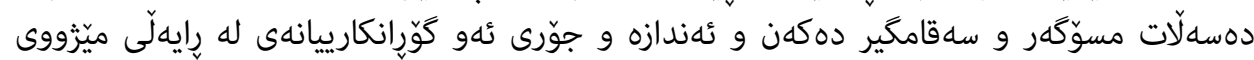

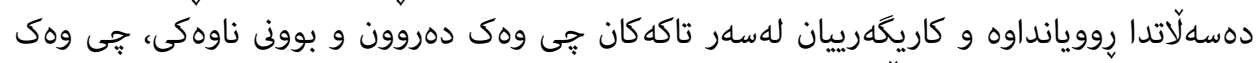

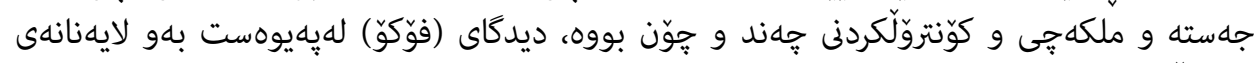

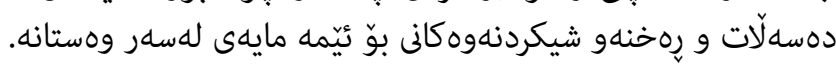

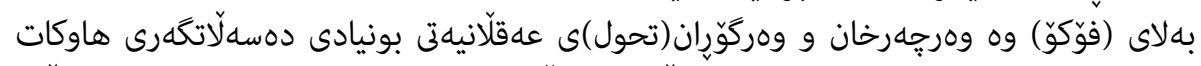

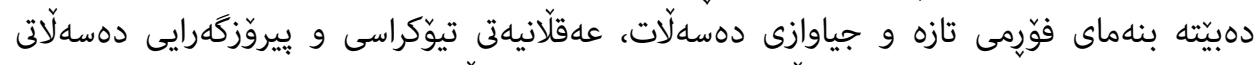

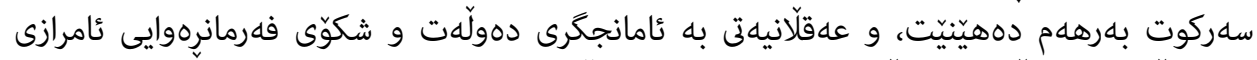

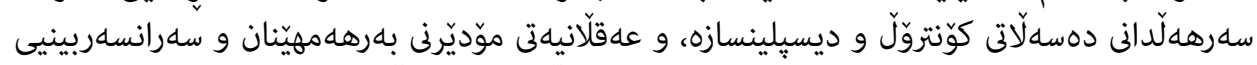

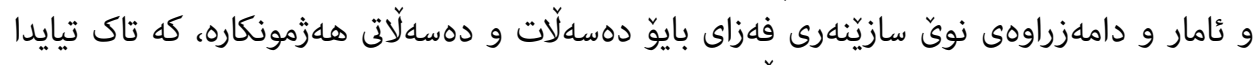

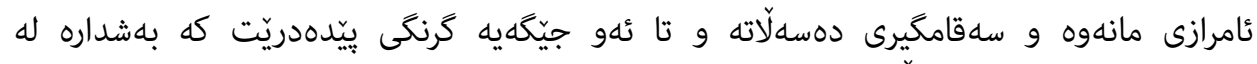

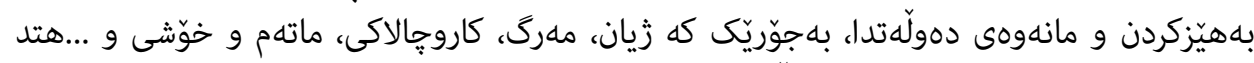

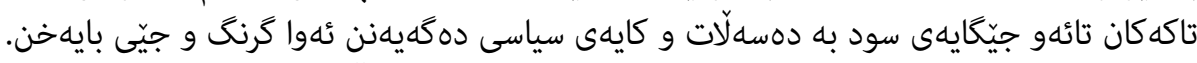

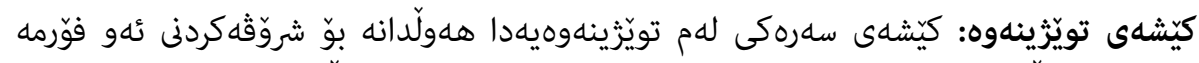

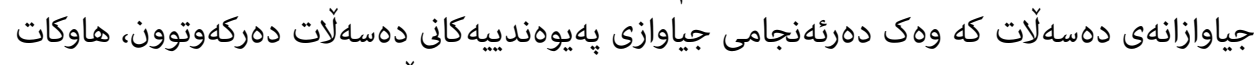

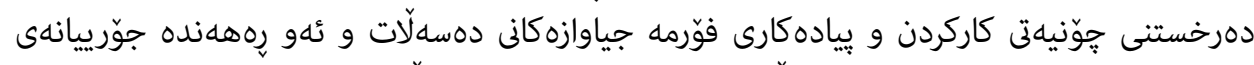

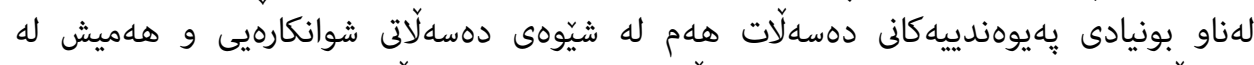

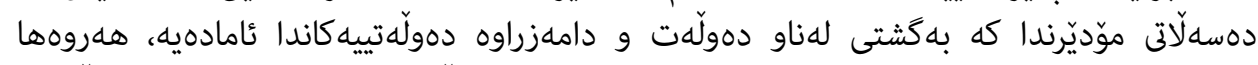

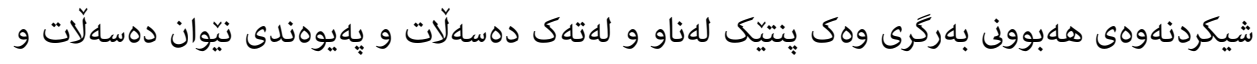
بهريدا.

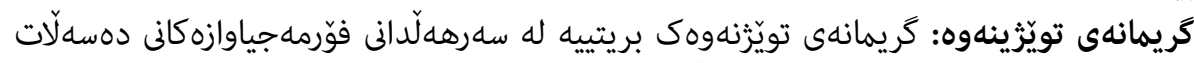

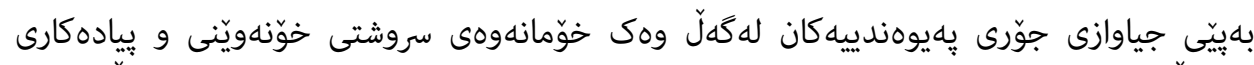

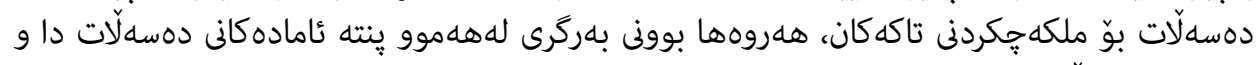

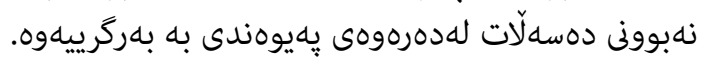

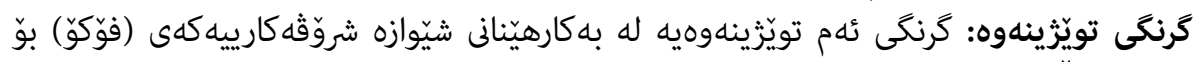

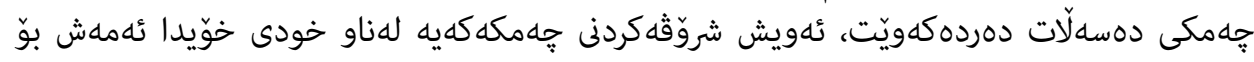

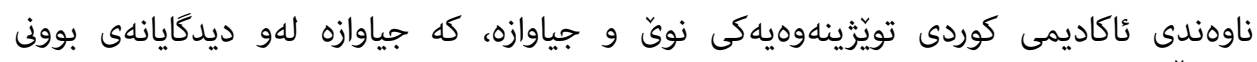

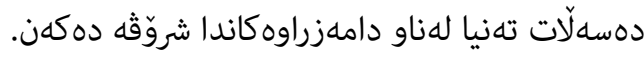


ئامانجه كانى تويّزينهوه: كرنكَترين ئامانجه كانى ئهم تويّزينهوهيه بريتين له:

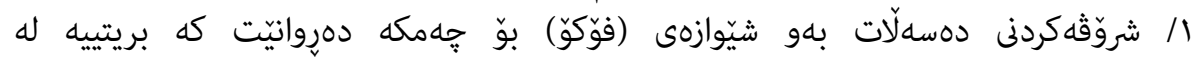

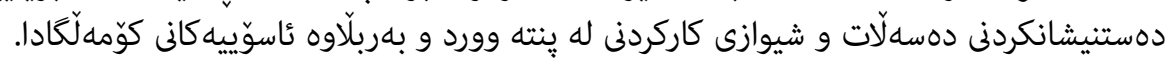

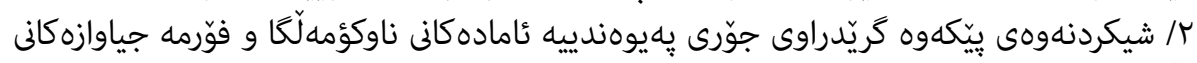

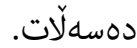

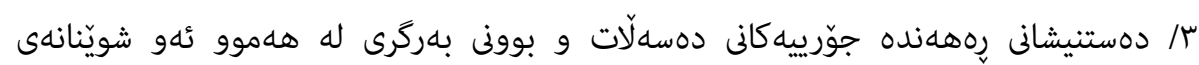
دهسلَات تيايدا ئامادهيه.

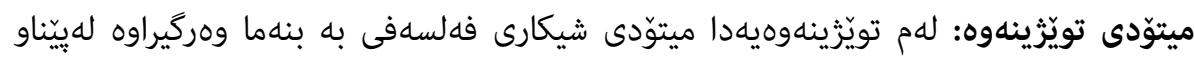

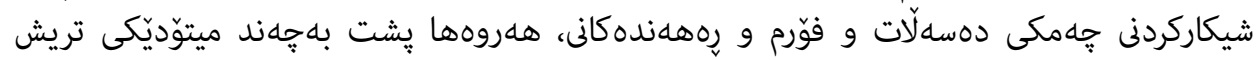

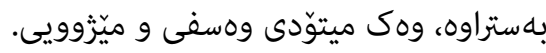

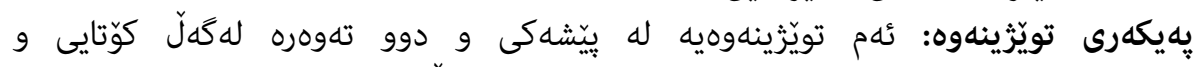

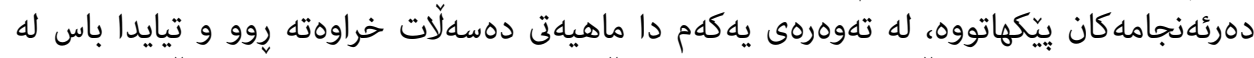

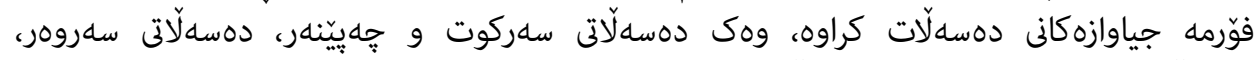

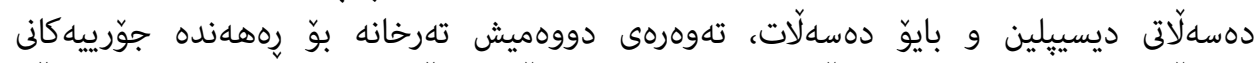

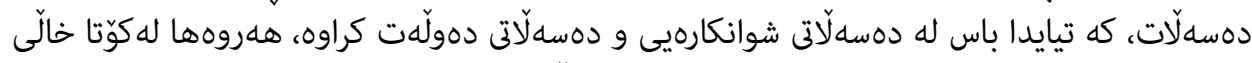

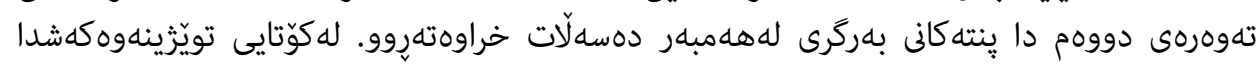

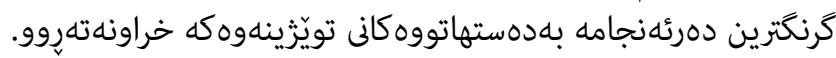




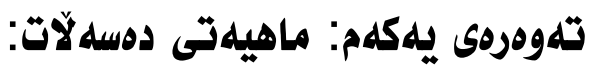

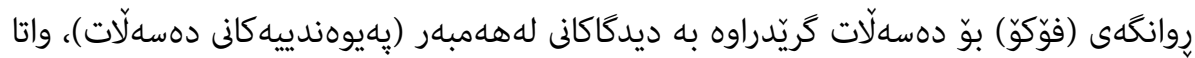

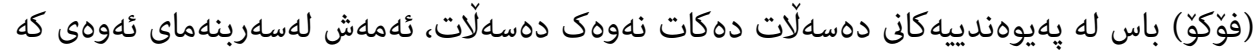

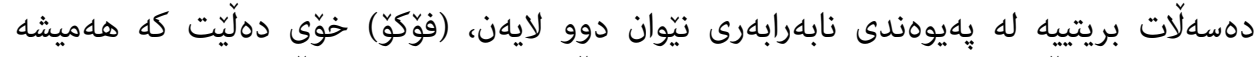

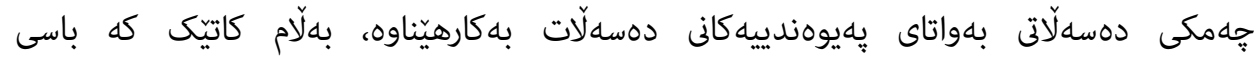

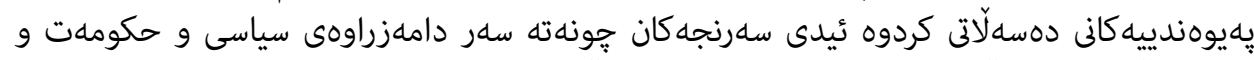

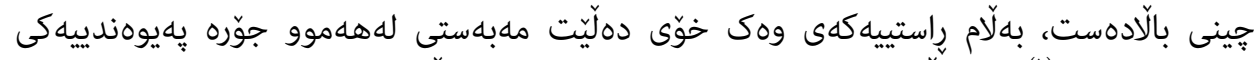

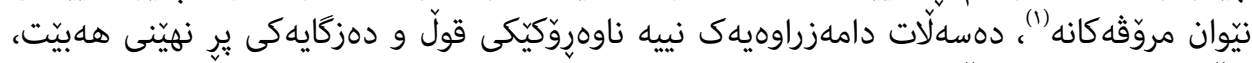

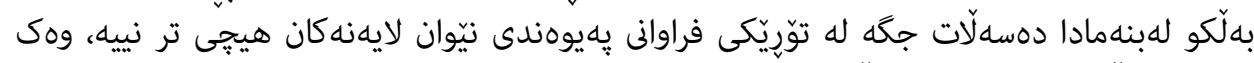

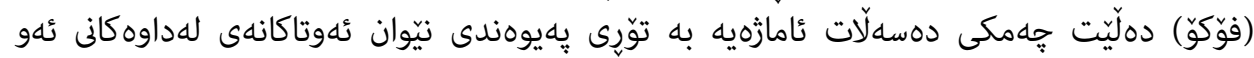

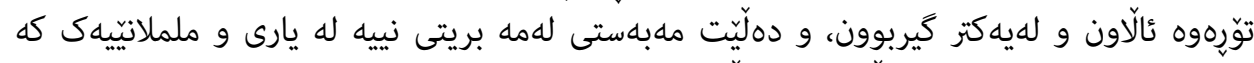

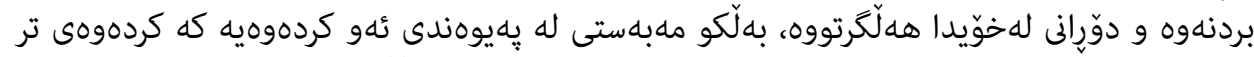

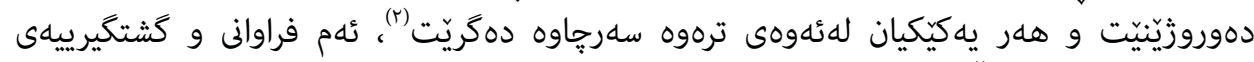

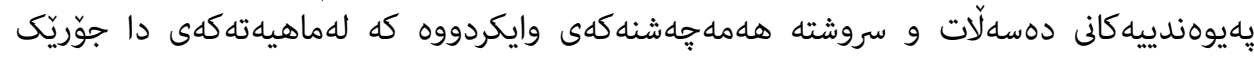
لهفرهيى و نواندنكارى شويّن- كاته كان بيّيت.

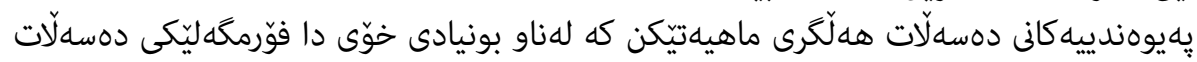

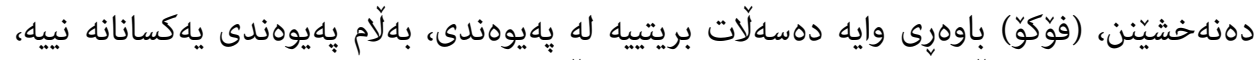

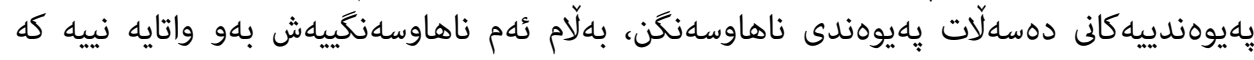

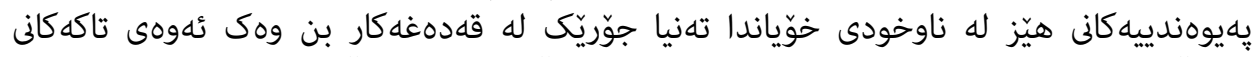

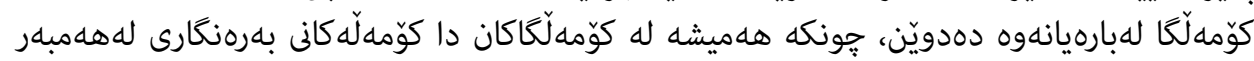

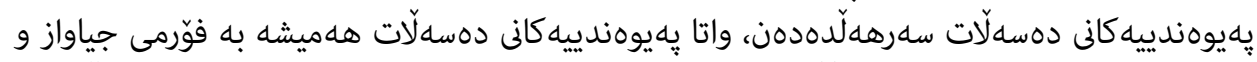

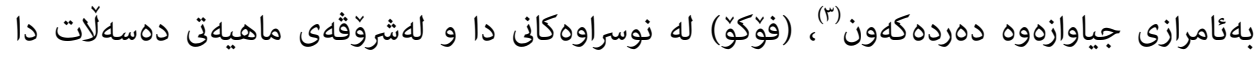

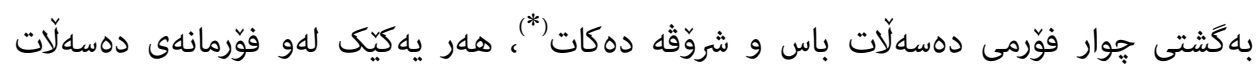

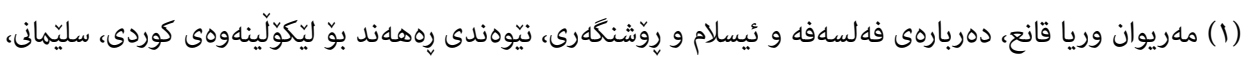

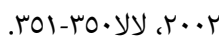

(2) Michel Foucault, critical inquiry- vol 8 - subject and power, translated from the French by: Leslie Sawyer, The University of Chicago Press, Chicago, 1982, p786.

(3) Michel Foucault, Power- Moral Values- and the Intellectual (Interview with Michel Foucault By: Michel Bess), Nov. 3, 1980, look this link: https://www.michaelbess.org/foucault-interview/ .

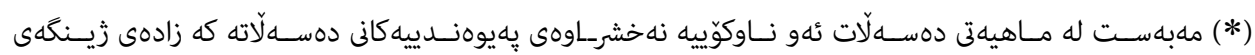

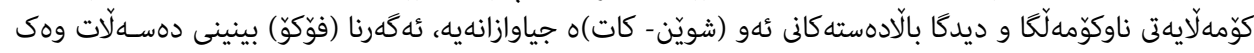


لهجوّريّكى جياواز له يهيوهنديدان، ئهوانيش بريتين له دهسهلآتى سهركوت و جِهِيِنهر، دهسهلآتى

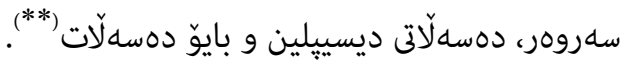

\section{يه كهم: دهسهلآتى سهركوت و جِهِيَنه}

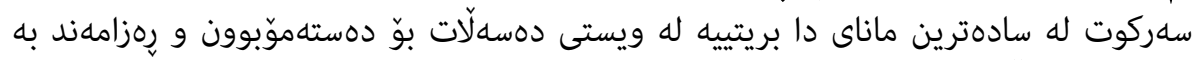

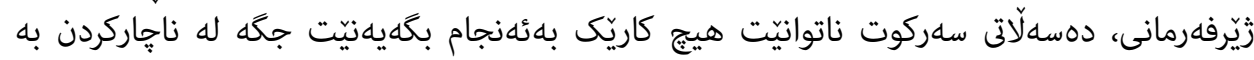

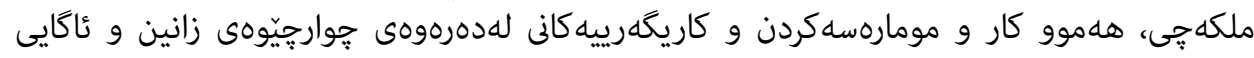

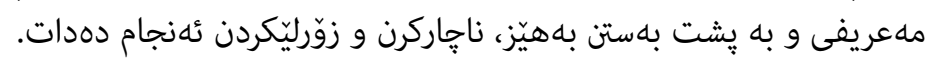

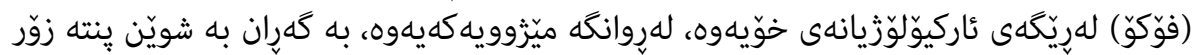

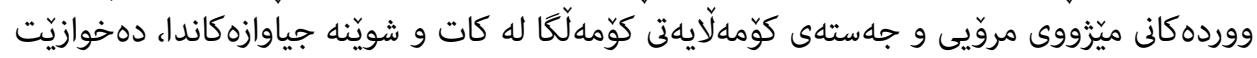

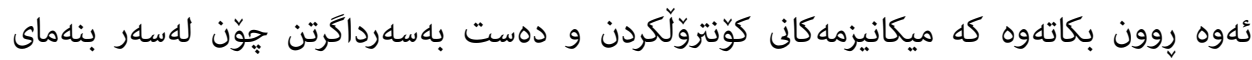

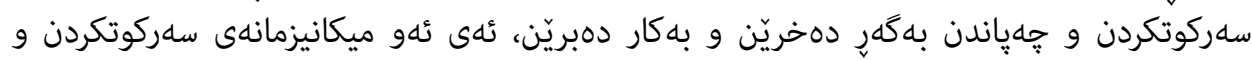

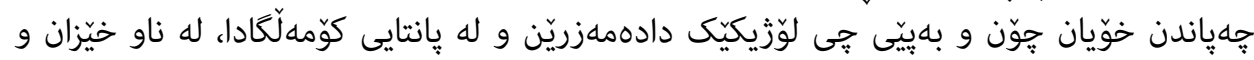

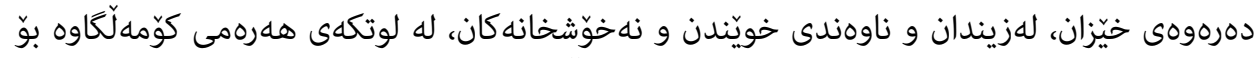

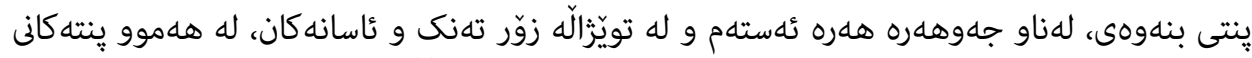

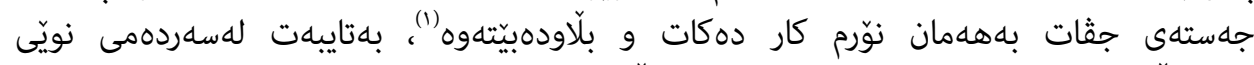

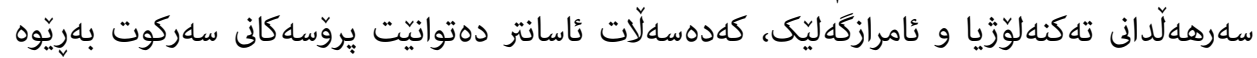

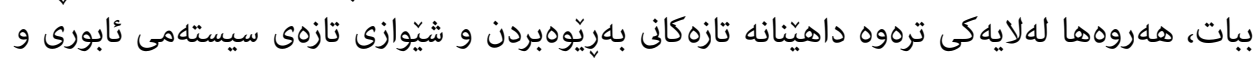

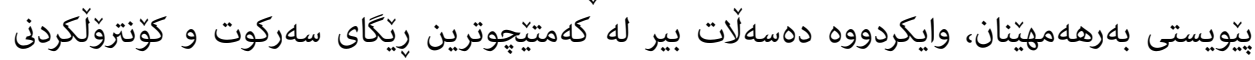

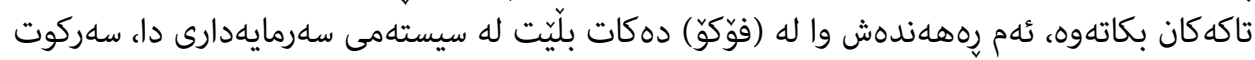

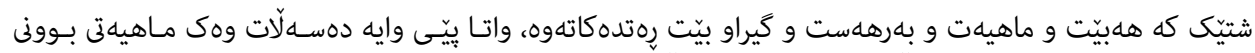

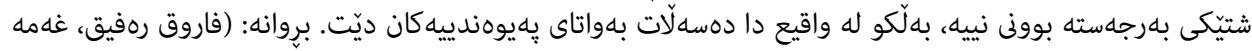

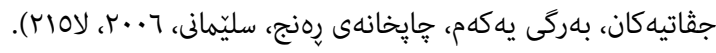

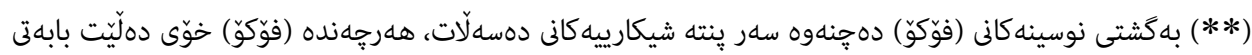

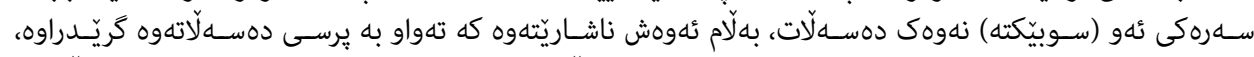

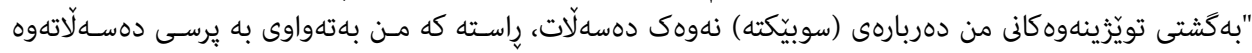

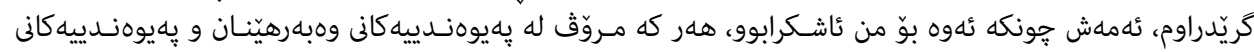

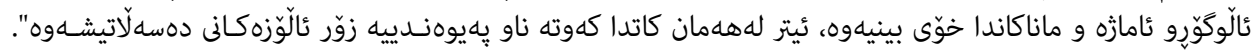

(Michel Foucault, critical inquiry- vol 8 - subject and power, op.cit, p778).

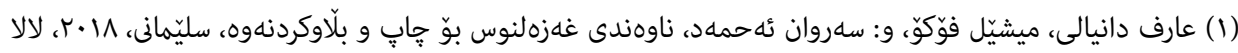




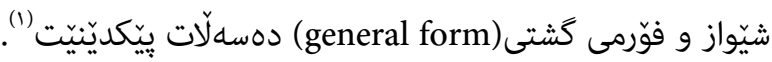

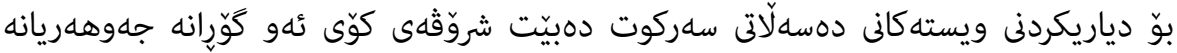

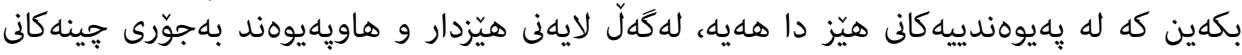

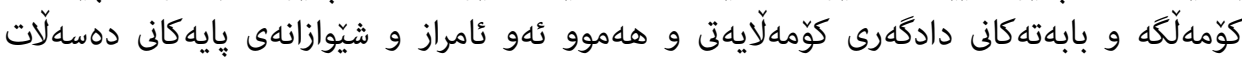

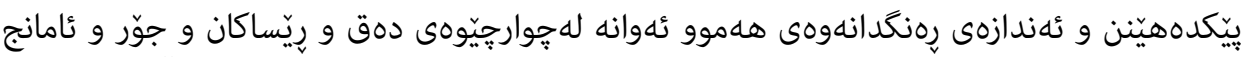

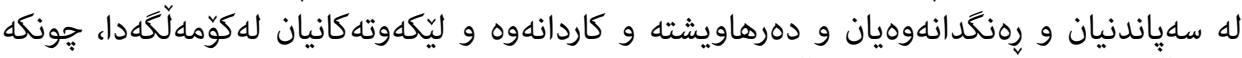

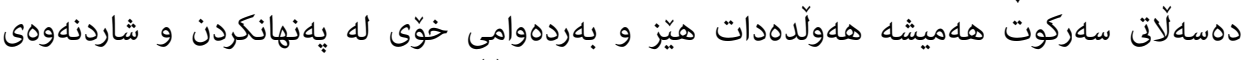

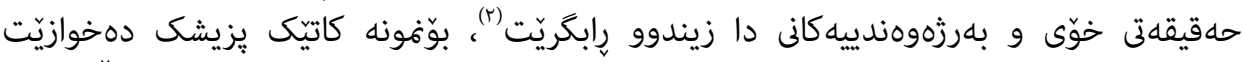

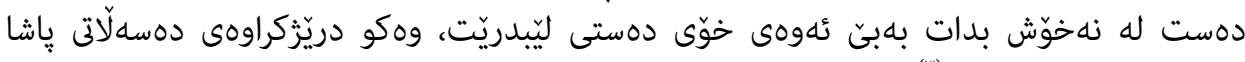

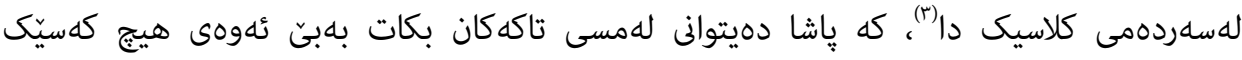

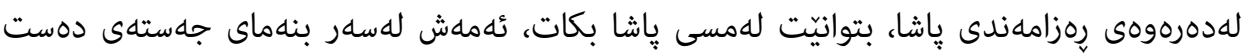

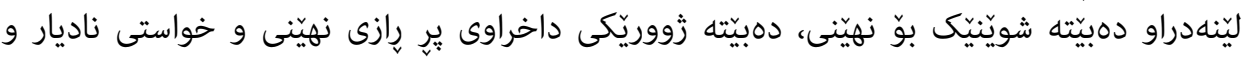

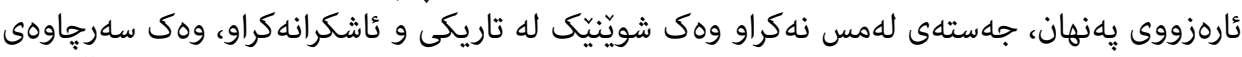

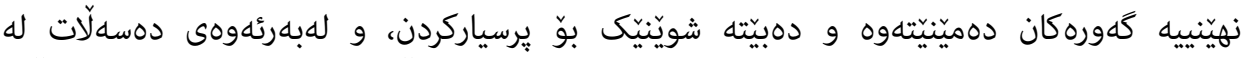

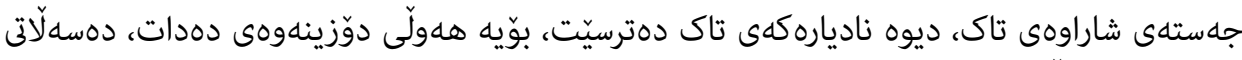

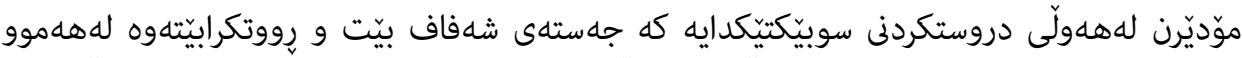

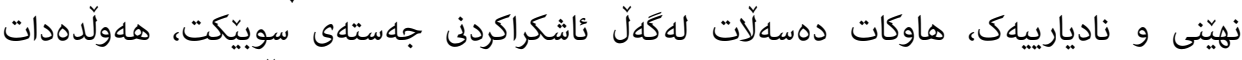

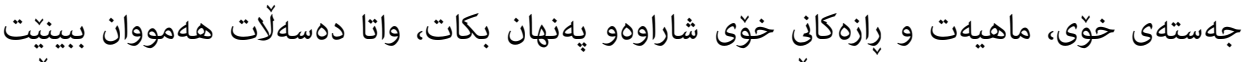

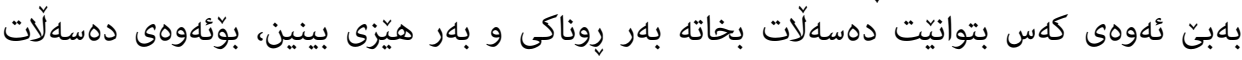

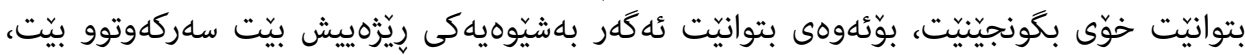

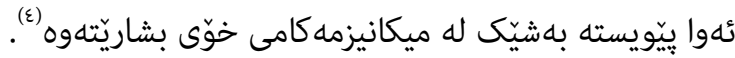

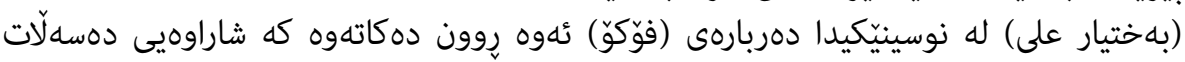

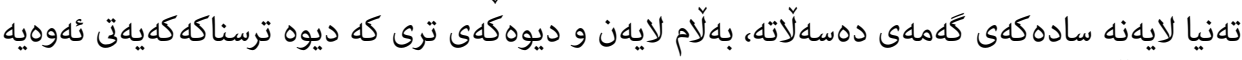

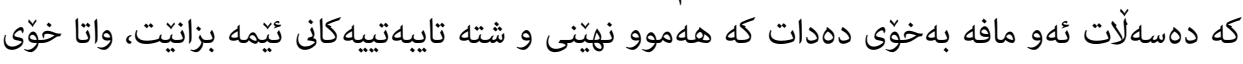

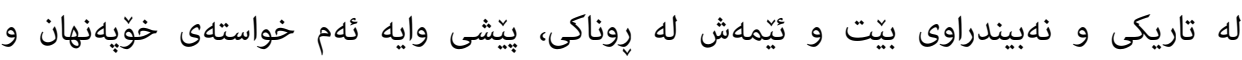

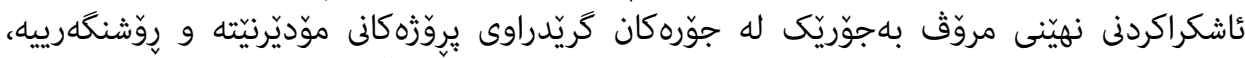

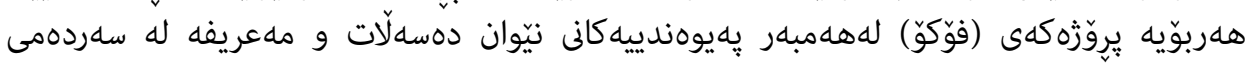

(1) Hubert L. Dreyfus and Paul Rabinow, Michel Foucault: beyond structuralism and hermeneutics, The University of Chicago, Chicago, 1983, p128.

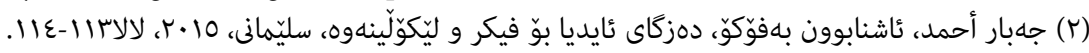

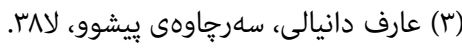

(4) Michel Foucault, the history of sexuality- vol 1, translated by: Robert Hurly, Pantheon Books, New York, 1978, p86. 


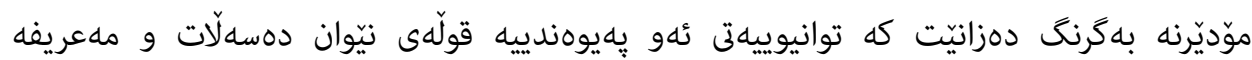

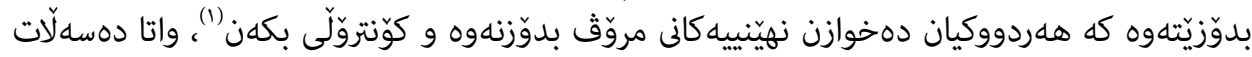

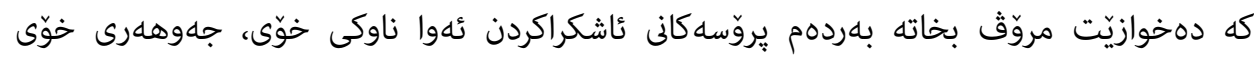

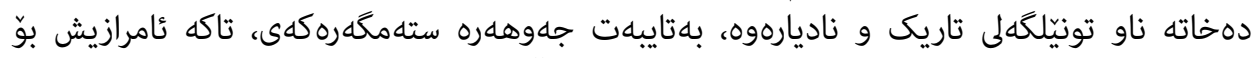

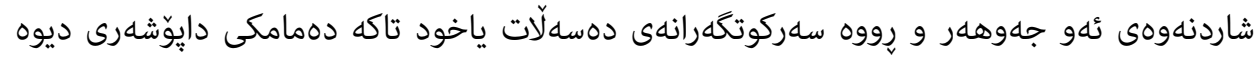

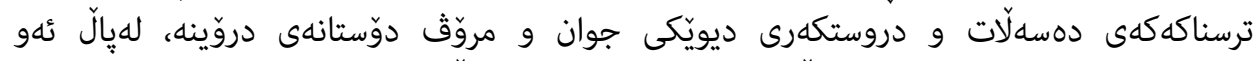

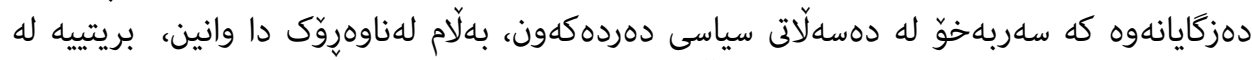

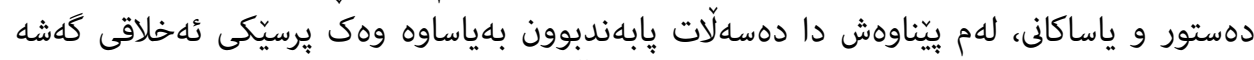

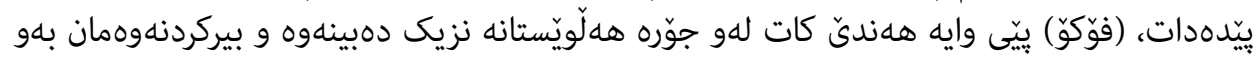

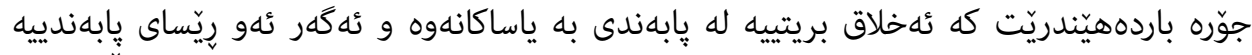

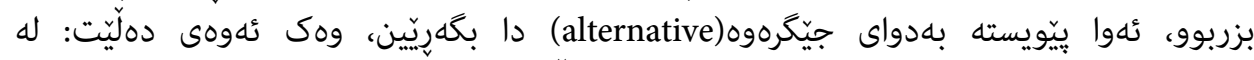

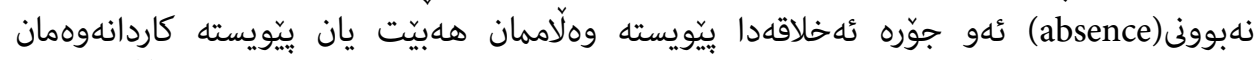

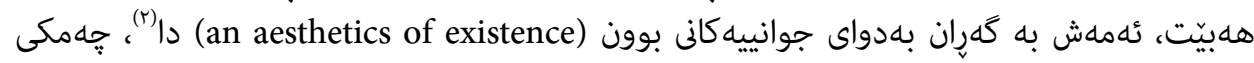

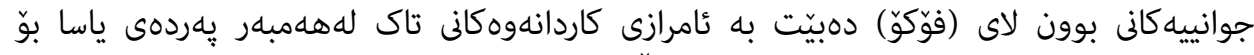

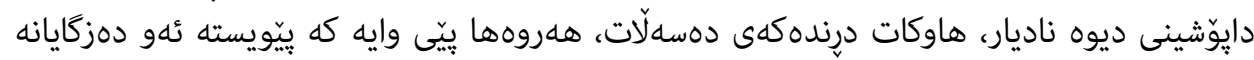

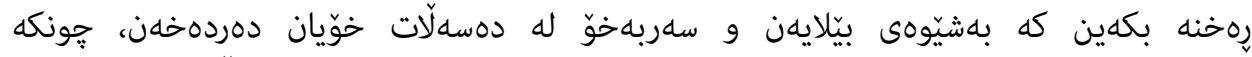

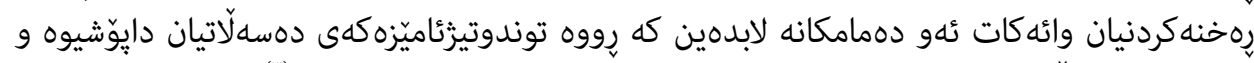

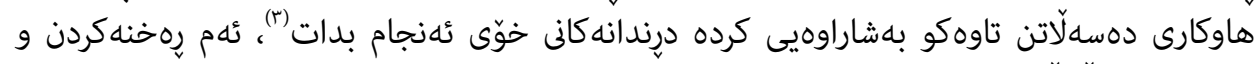

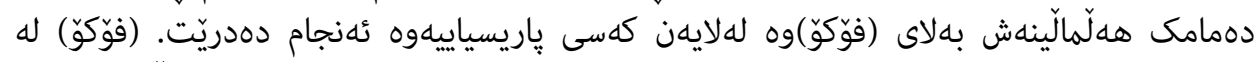

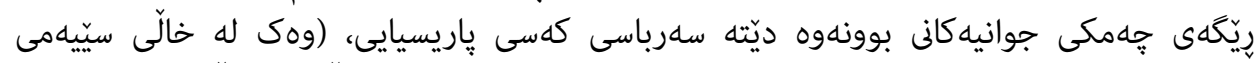

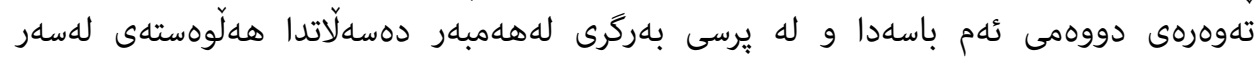

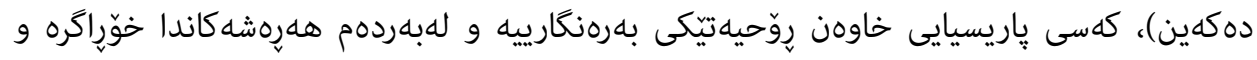

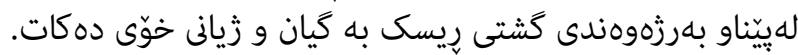

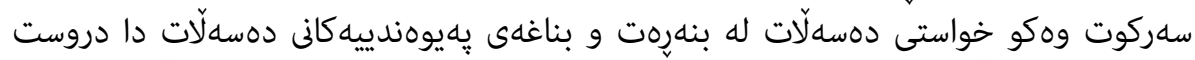

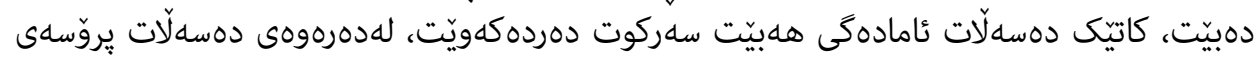

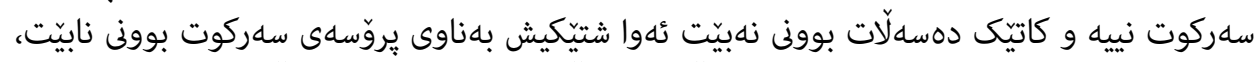

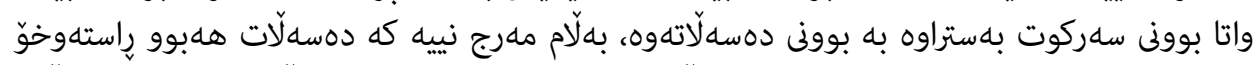

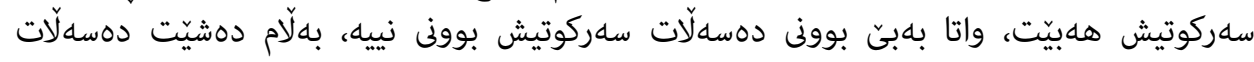

(1) به ختيار على، ناورِكهى ئوّرفيوّس، ناوهندى روّشنبيرى و هونهرى ئهنديّشه، سليّمانى، عا • ب، لالابع-عع. (2) Alan Milchman and Alan Rosenberg Editors, Foucault and Heidegger - Critical Encounters, University of Minnesota Press, London, 2003, p223.

(3) Michel Foucault and Noam Chomsky, The Chomsky-Foucault Debate On Human Nature, The New Press, New York, 2006, p41. 


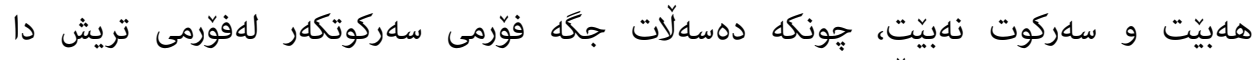

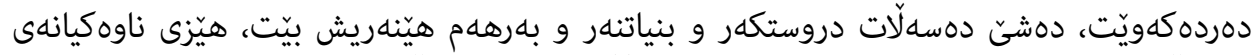

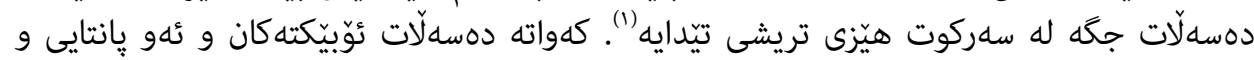

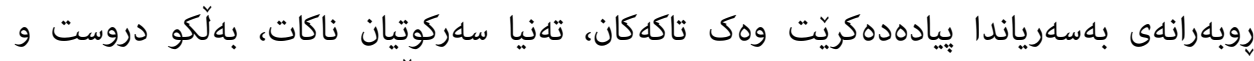

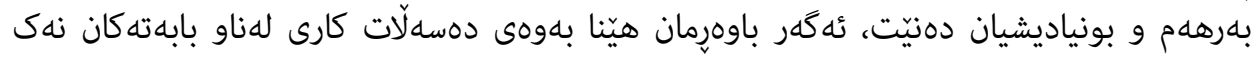

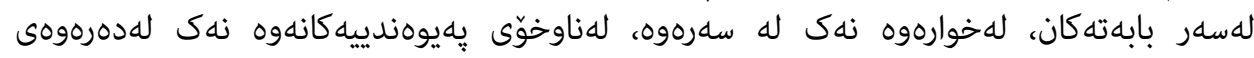

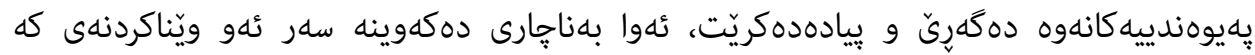

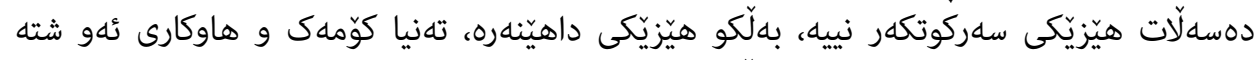

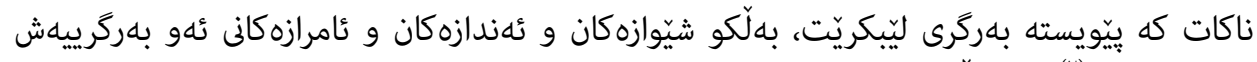

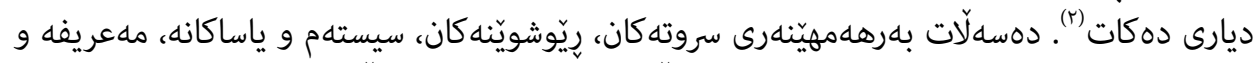

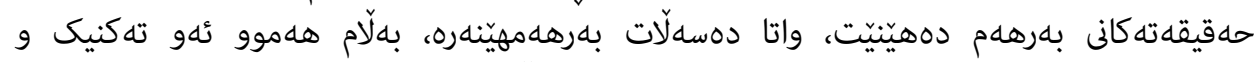

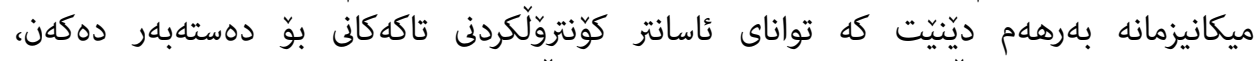

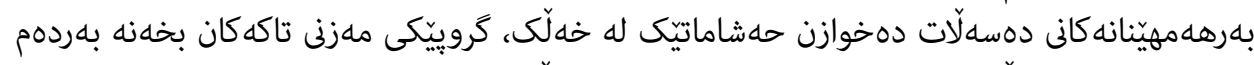

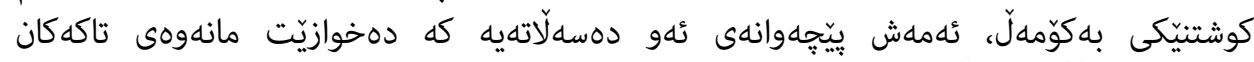

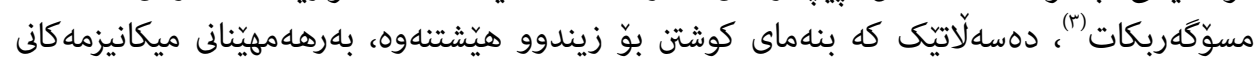

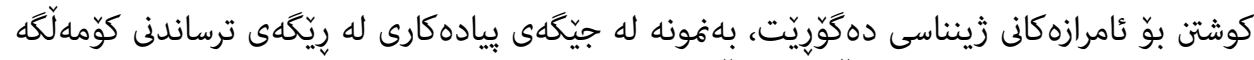

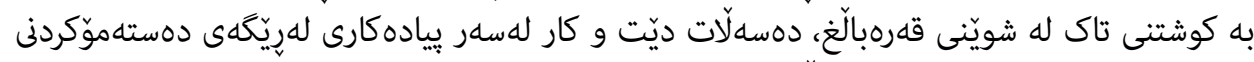

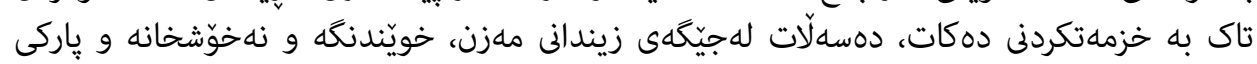

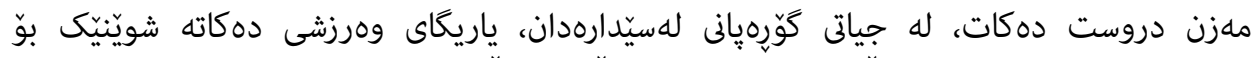

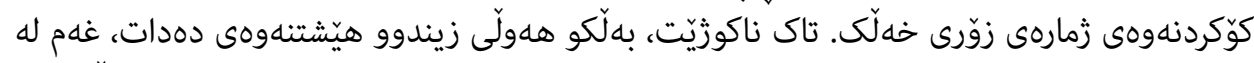

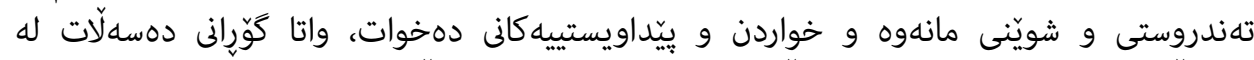

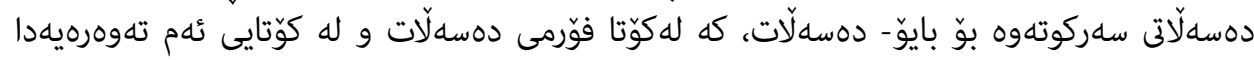

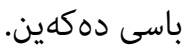

\section{دووهم: دهسه لَّتى سهروهر:}

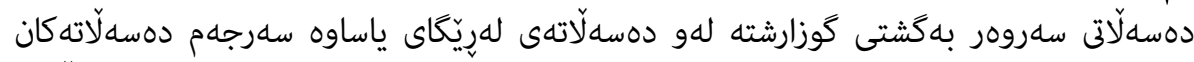

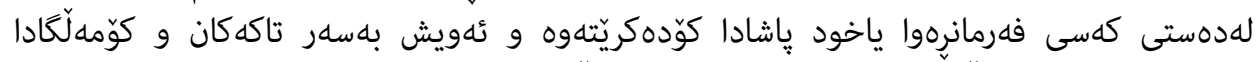

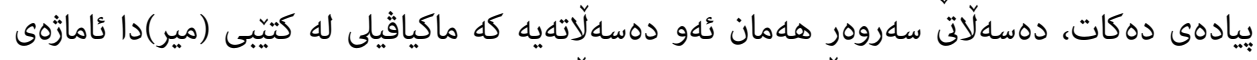

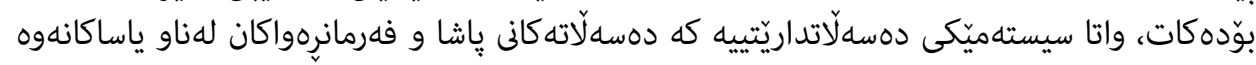

(1) جهبار أحمد، سهرجاوهى يِيشوو ، لا• (11)

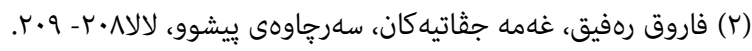

(3) Michel Foucault, the history of sexuality- vol 1, op.cit, p137. 
ديّت و دواتر خوّيان دهبن به سهنتهر و ناوهندى يِيادهكردنى دهسهلّات بهشيّوهيهكى ستونى لهسهرهوه

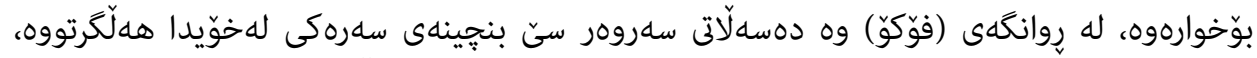

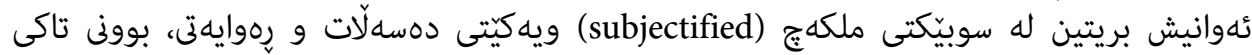

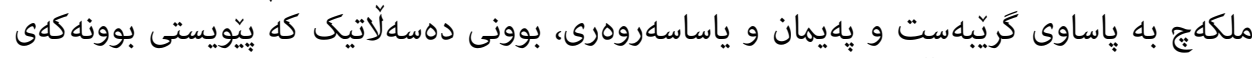

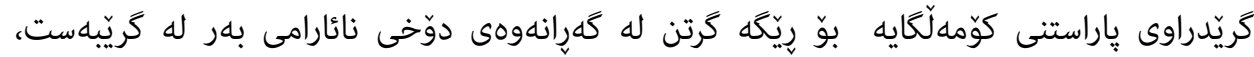

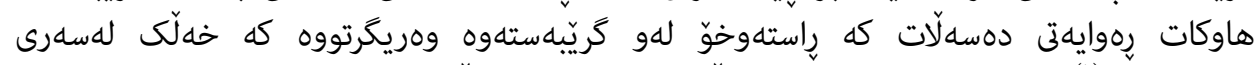

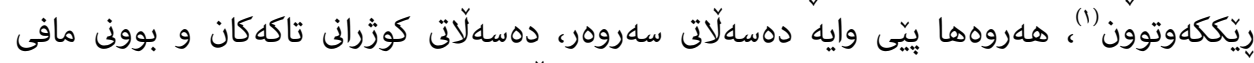

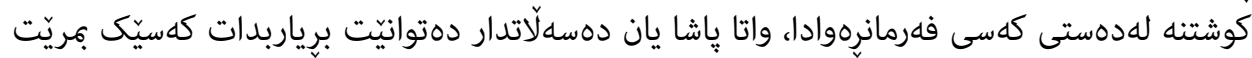

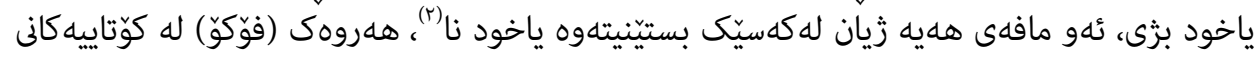

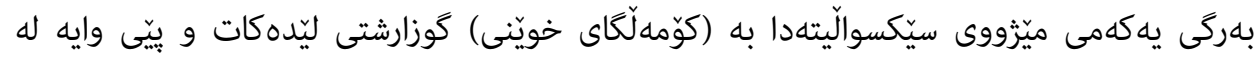

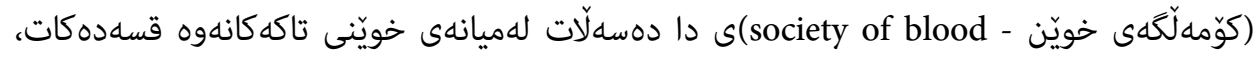

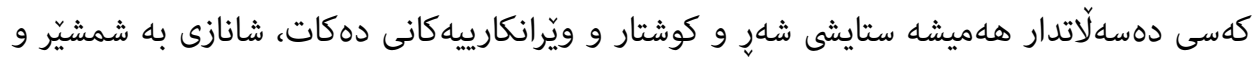

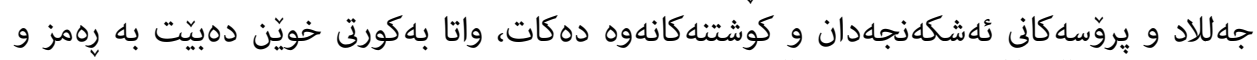

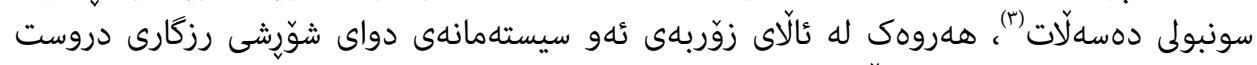

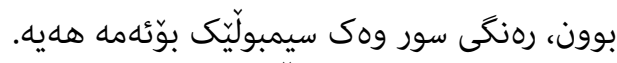

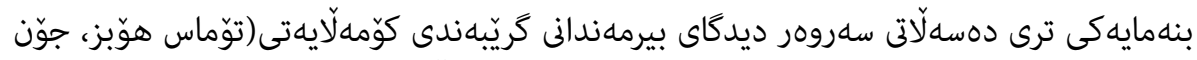

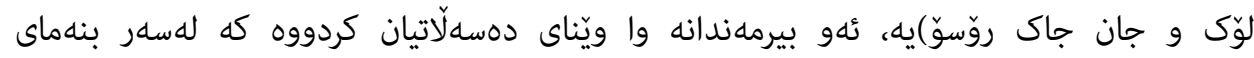

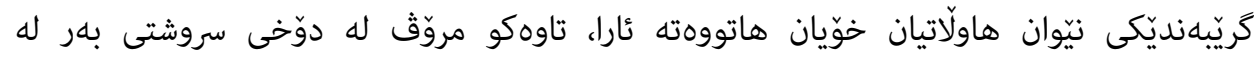

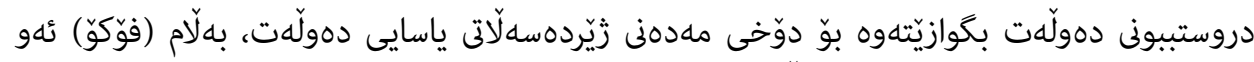

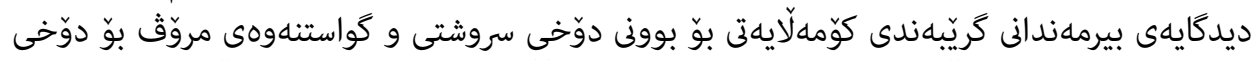

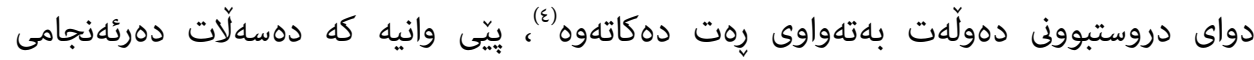

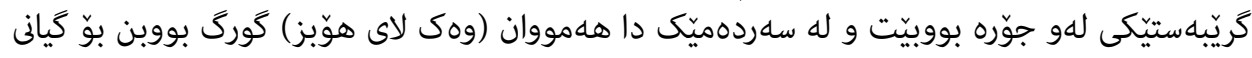

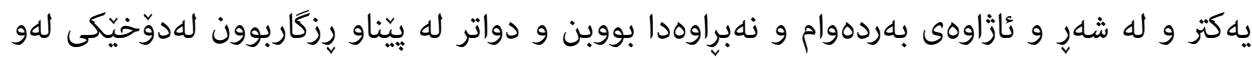

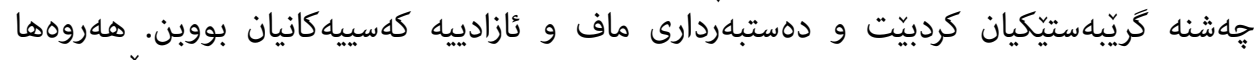

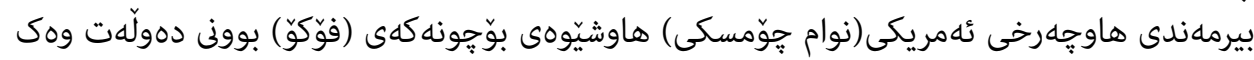

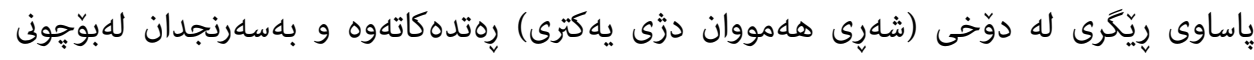

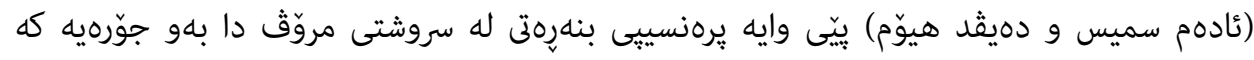

(1) Michel Foucault, Society Must Be Defended- Lectures At The College De France 1975-1976, translated by: David Macey, published by Picador. New York, 2003, p44.

(2) ibid, p240.

(3) Michel Foucault, the history of sexuality- vol 1, op.cit, p147.

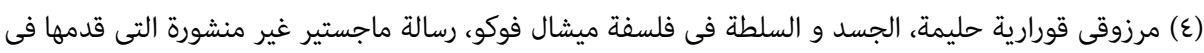

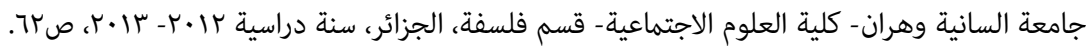




\section{يهيوهندييه مروّييه كان بهشيّوهيهكى ناشتيانه بهرِيوهوه جوون (1).}

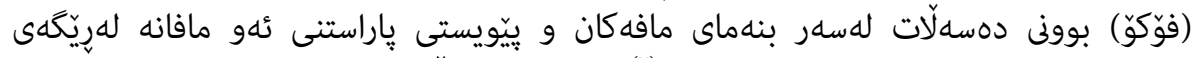

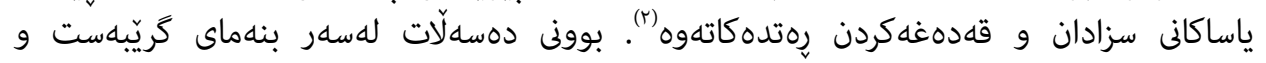

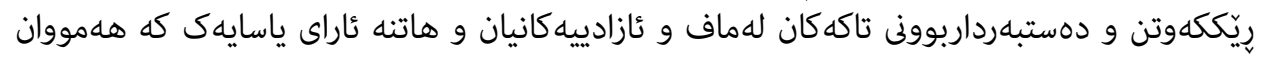

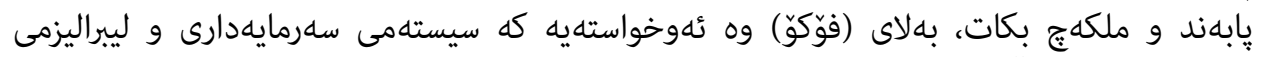

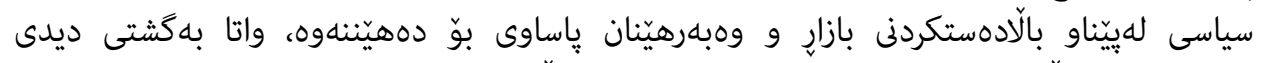

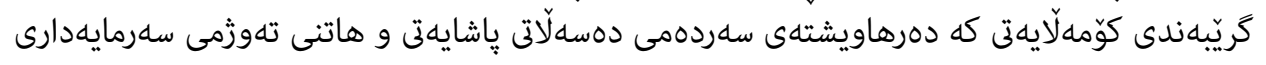

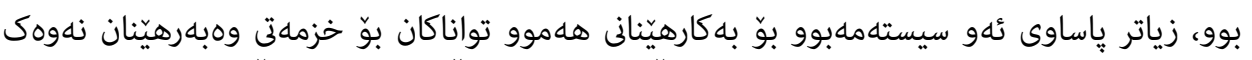

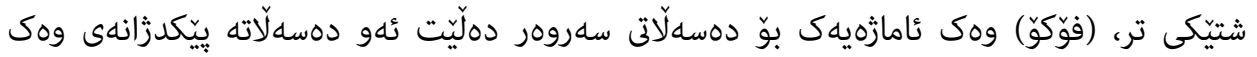

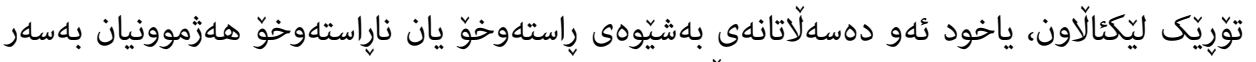

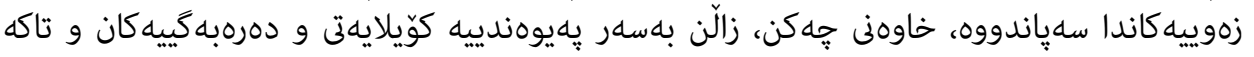

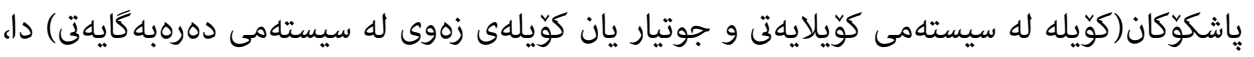

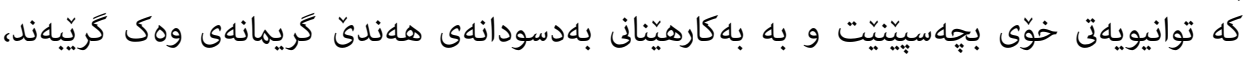

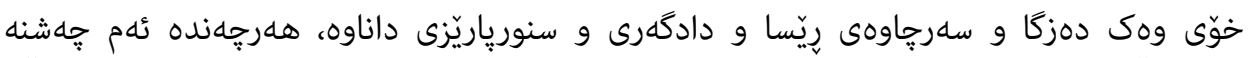

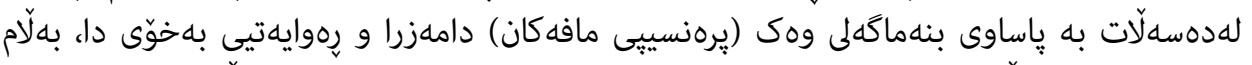

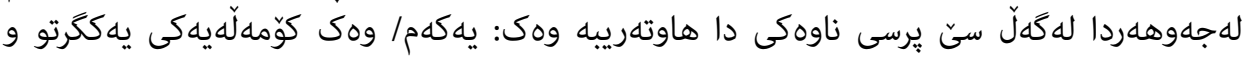

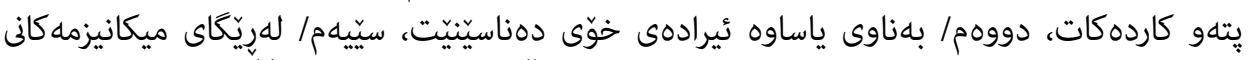

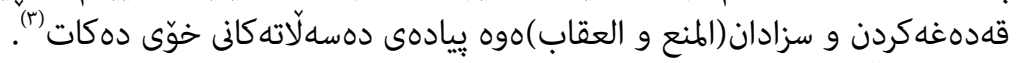

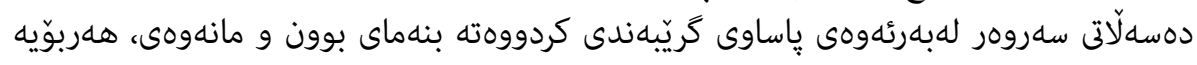

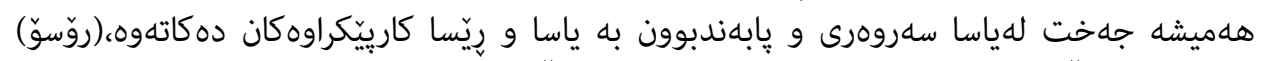

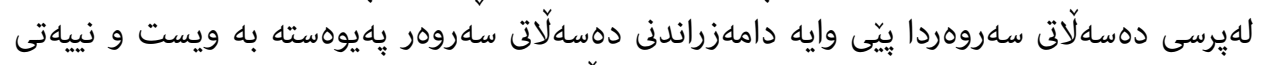

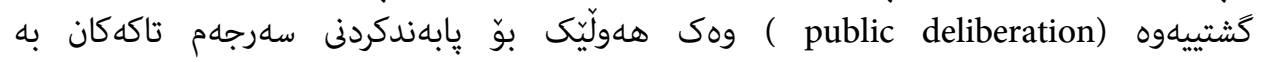

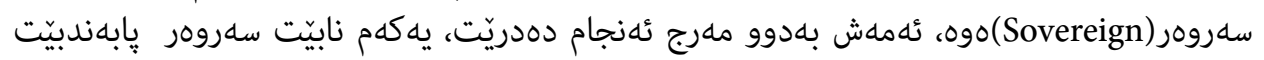

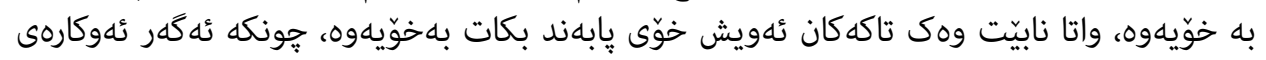

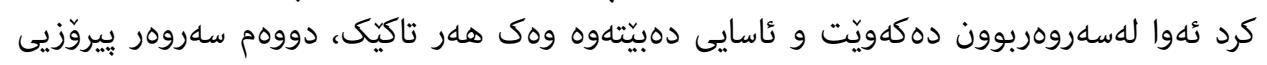

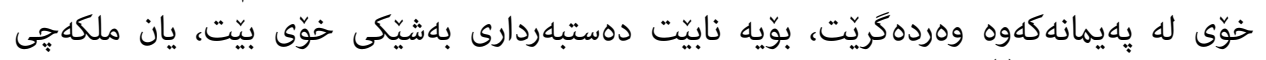

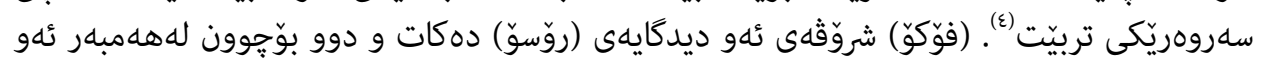

(1) نعوم تشومسكى و جون بريكمون، العقل ضد السلطة، ت: عبدالرحيم حزل، دار الآمان، بيروت، عا.r، ص صVV-

(r) (المصدر نفسه، الصفحة نفسها.

(3) Michel Foucault, the history of sexuality- vol 1, op.cit, pp86- 87.

(4) Jean Jacques Rousseau, The Social Contract- Or Principles Of Political Right, Translated by G.

D. H. Cole, public domain, 2002, pp 12- 13. 


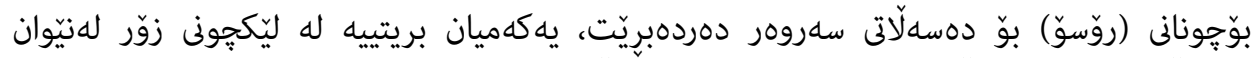

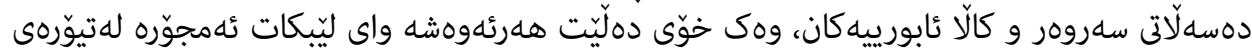

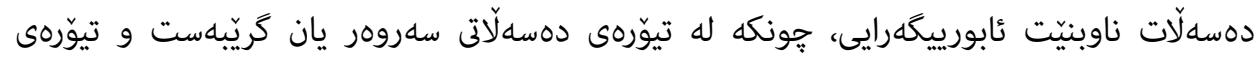

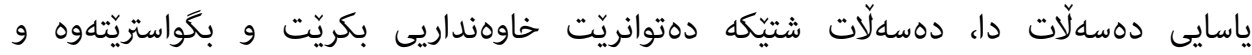

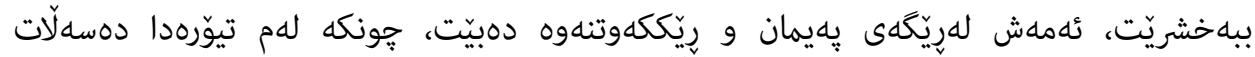

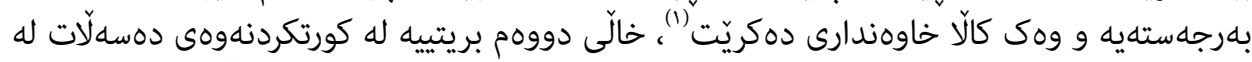

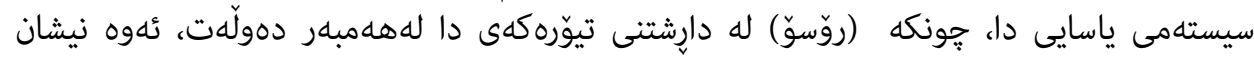

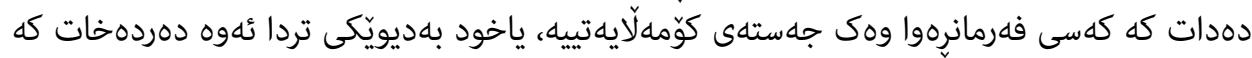

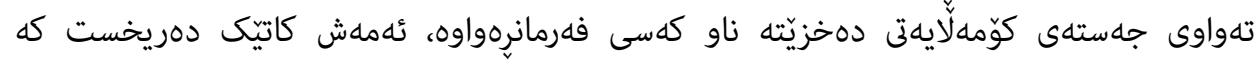

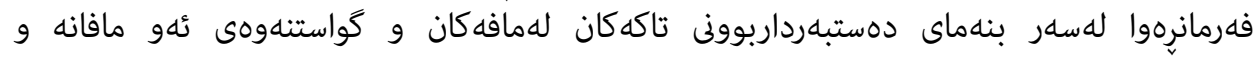

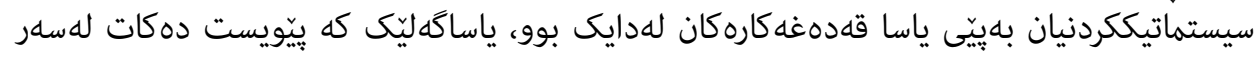

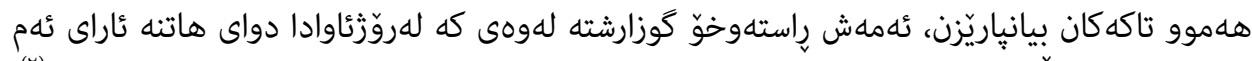

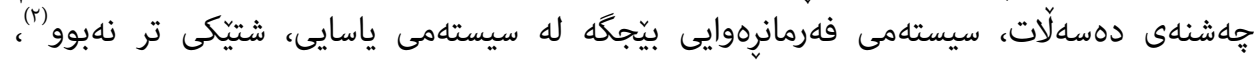

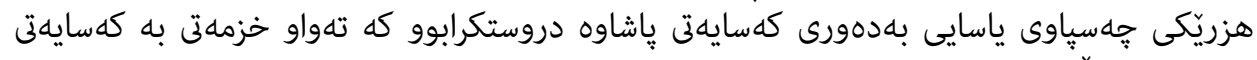

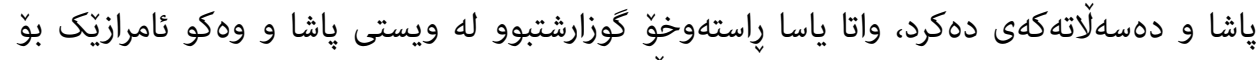

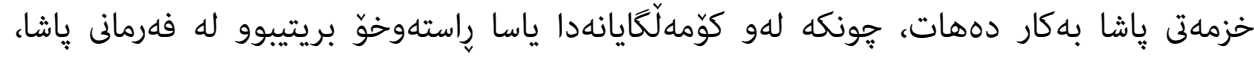

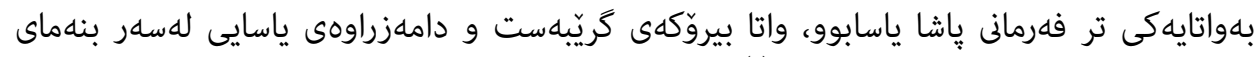

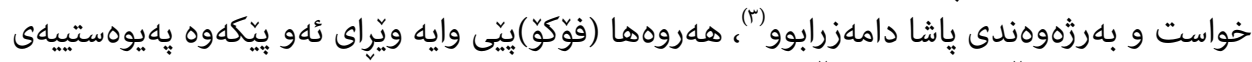

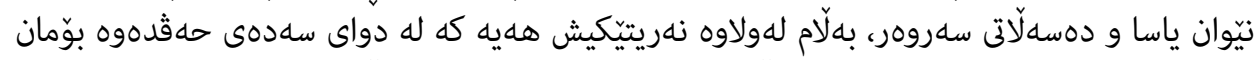

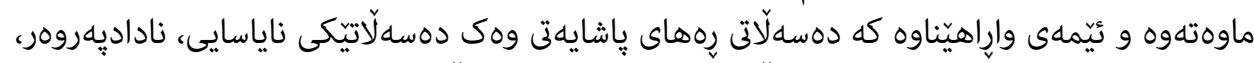

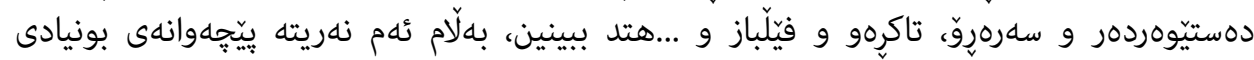

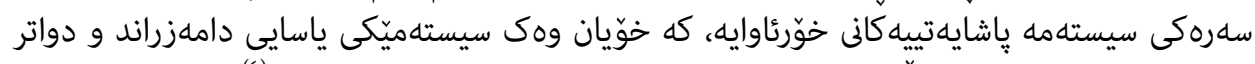

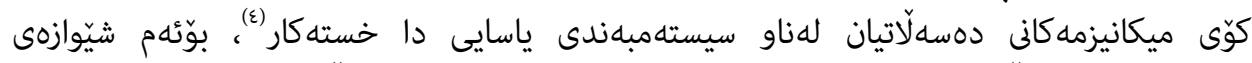

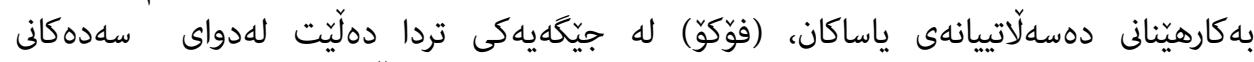

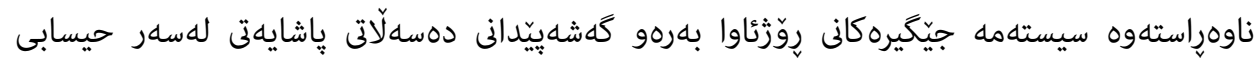

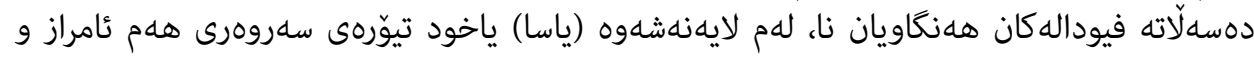

(1) Michel Foucault, Society Must Be Defended- Lectures At The College De France 1975-1976, op.cit, p13.

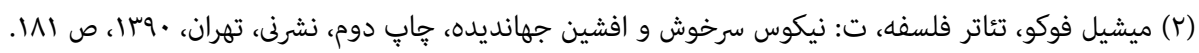
(3) Michel Foucault, Society Must Be Defended- Lectures At The College De France 1975-1976, op.cit, pp25-26.

(ع) ميشيل فوكو، اراده به دانستن، ت: نيكو سرخوش و افشين جهانديده، نشرن،، حابٍ ششم، تهران، •وبا، ص ص 


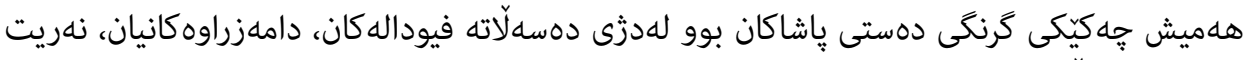

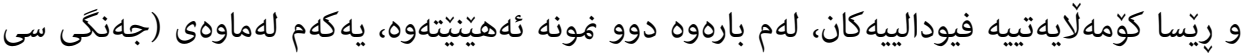

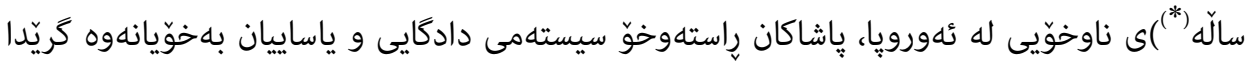

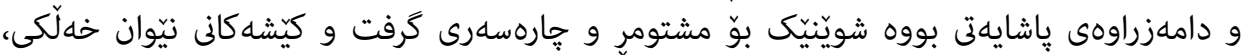

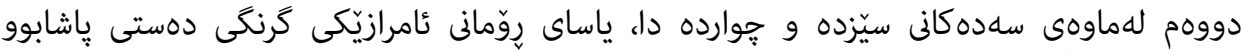

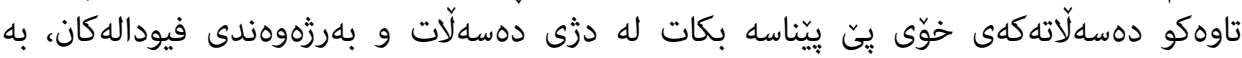

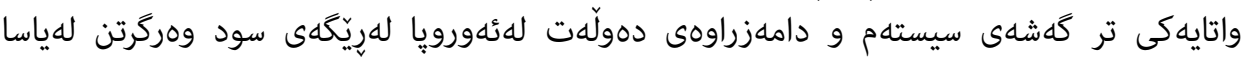

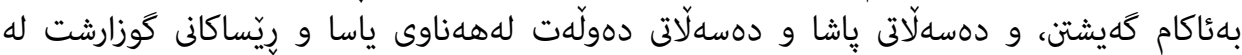

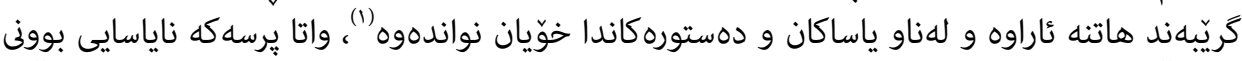

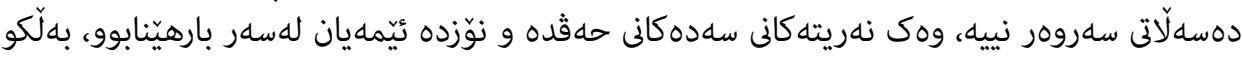

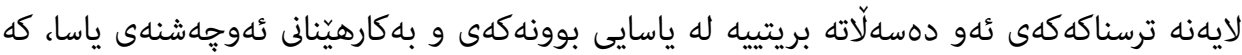

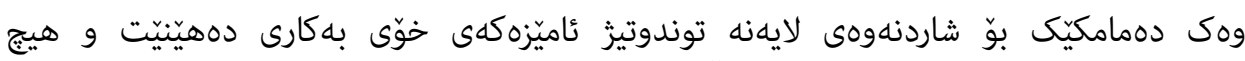

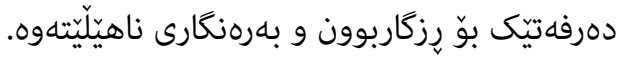

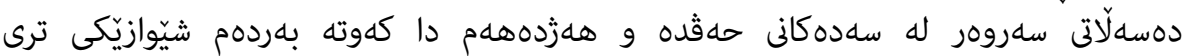

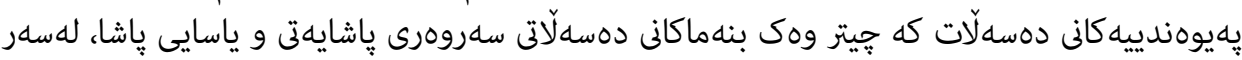

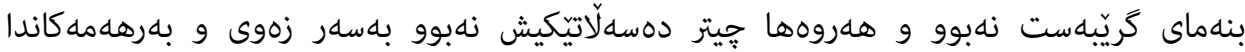

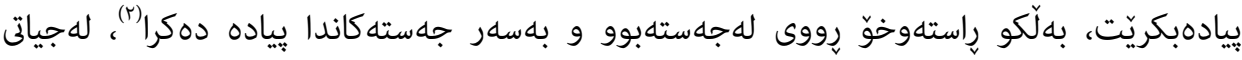

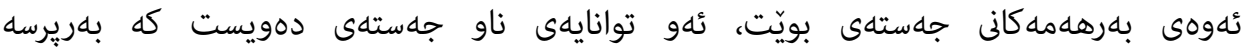

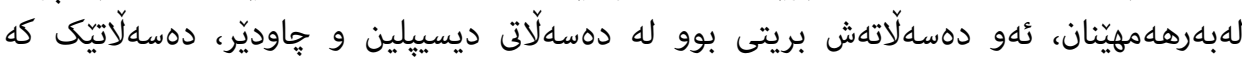

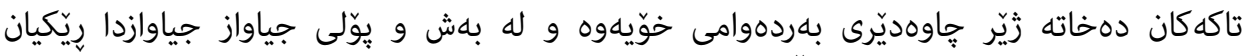

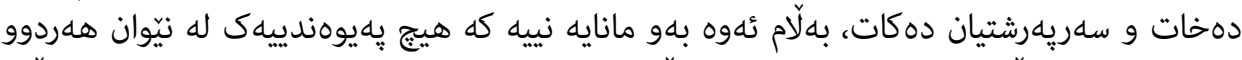

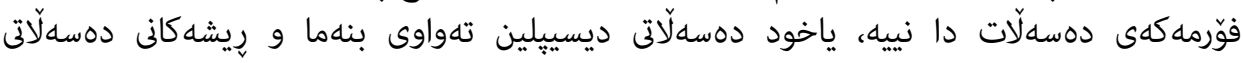

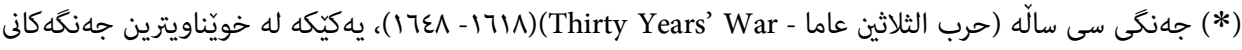

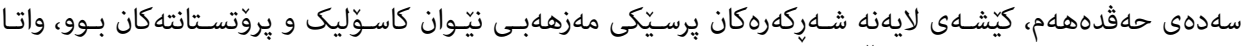

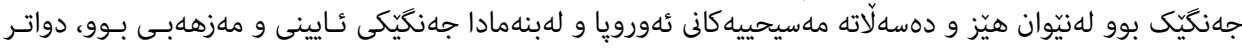

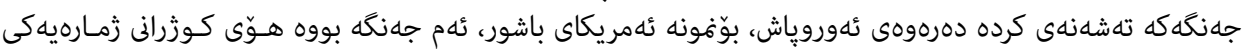

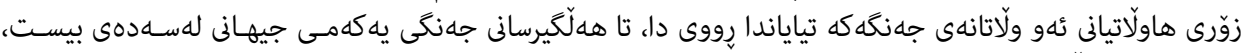

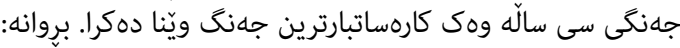

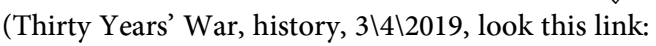
https://www.history.com/topics/reformation/thirty-years-war).

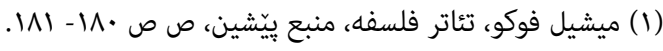

(2) Michel Foucault, Society Must Be Defended- Lectures At The College De France 1975-1976, op.cit, pp35-36. 


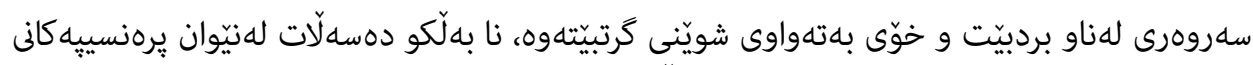

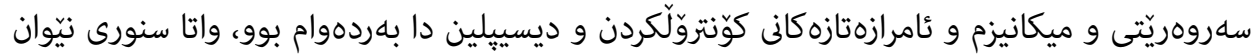

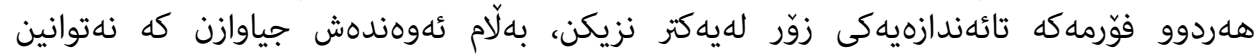

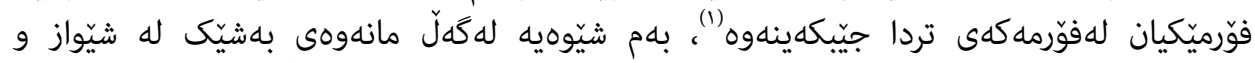

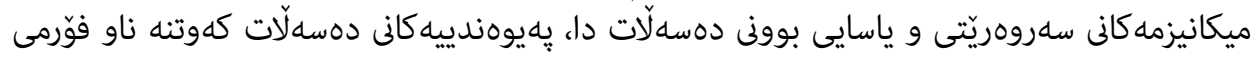

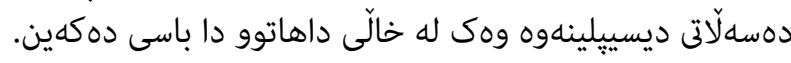

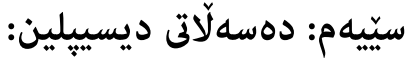

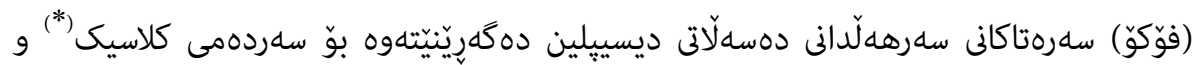

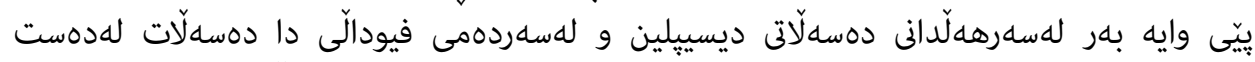

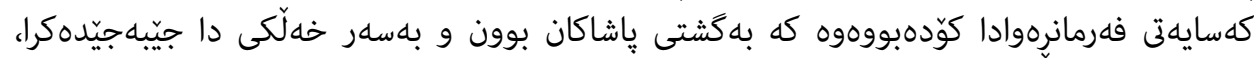

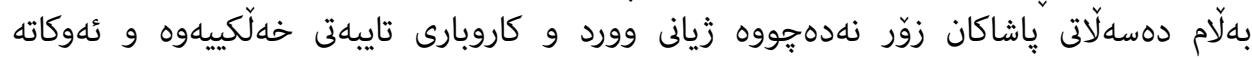

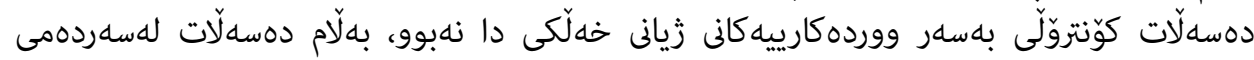

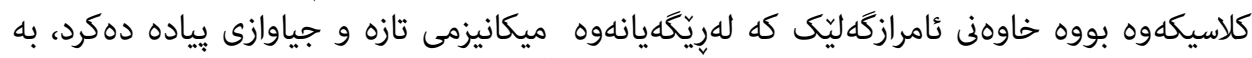

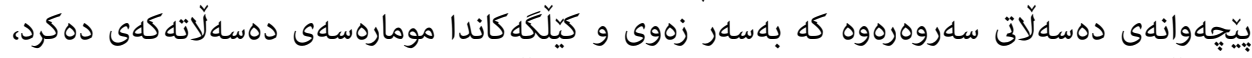

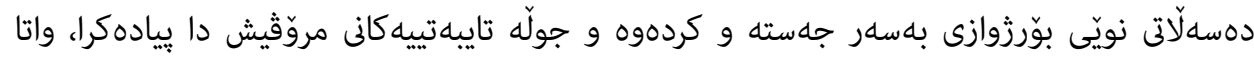

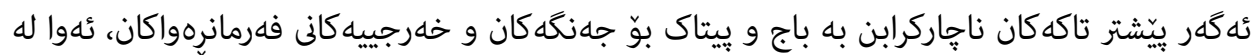

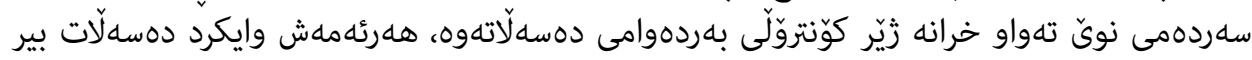

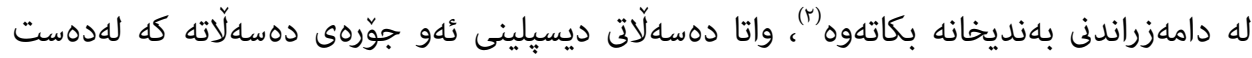

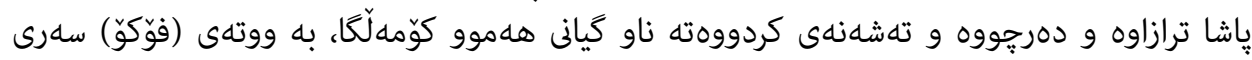

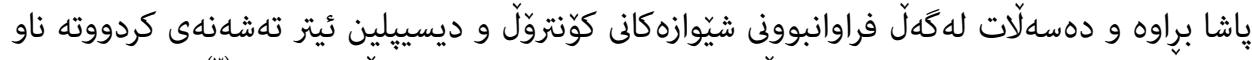

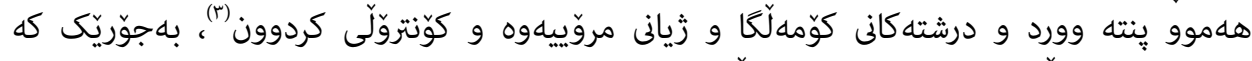

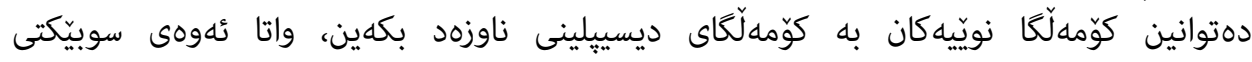

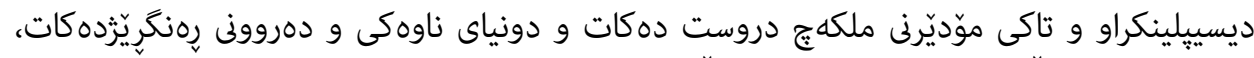

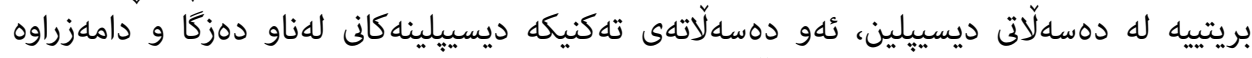

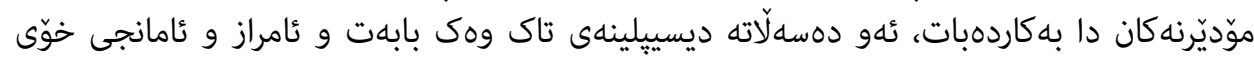

(1) ibid, p37.

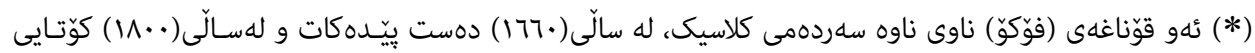

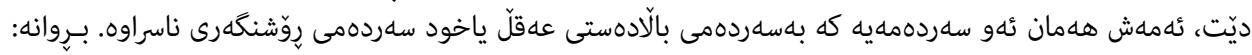

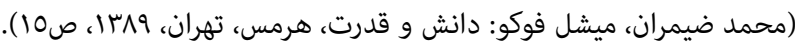

(2) Jose Guilherme Merquior, Foucault, University of California Press, U.S.A, 1985, pp 113.

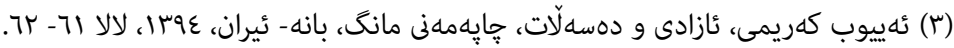




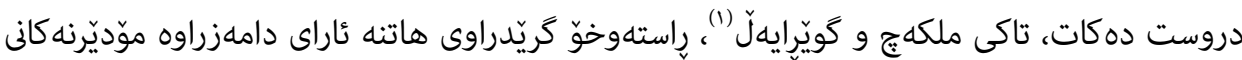

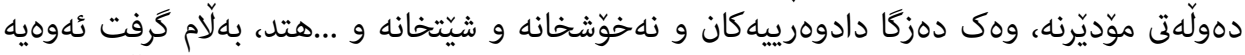

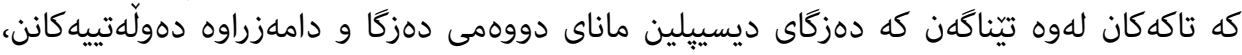

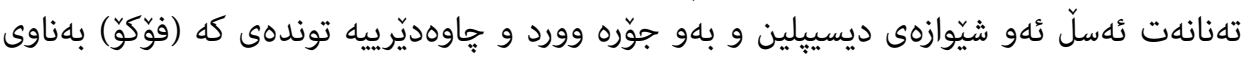

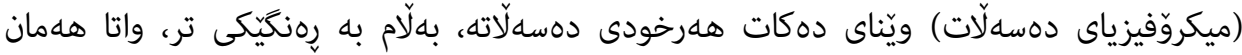

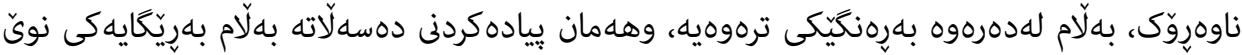

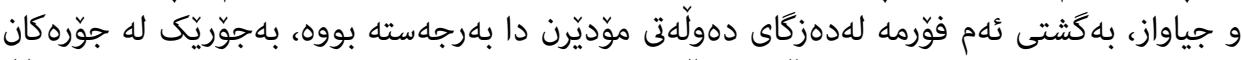

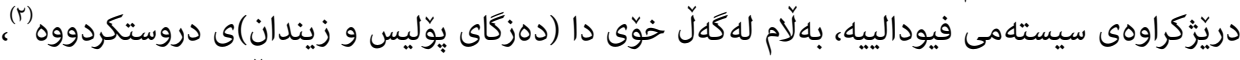

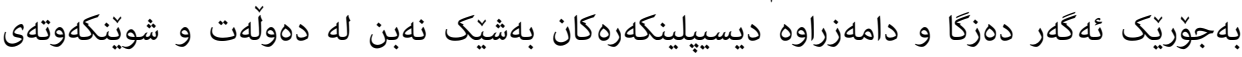

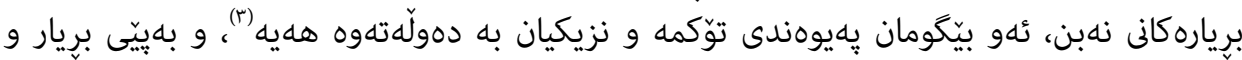

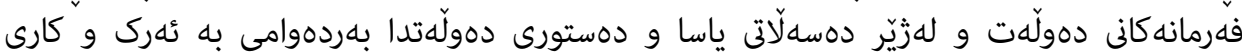
خوّيان دمدندن.

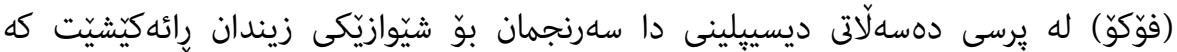

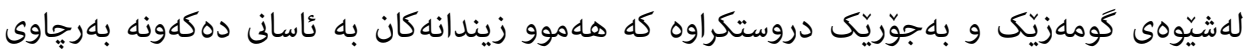

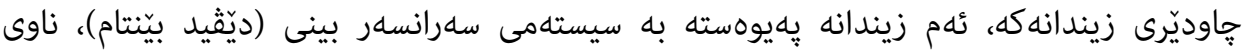

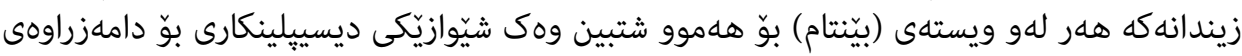

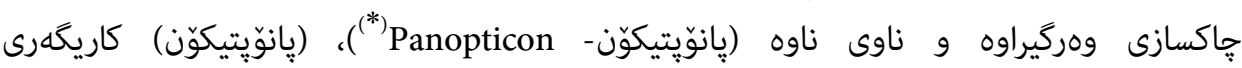

(1) مهريوان وريا قانع، ئه خلاق و بهركرى- سهرهتايهك بوّ ناسينى كارهكانى ميشيّل فوّكوّ، ناوهندى رِوَشنبيرى و

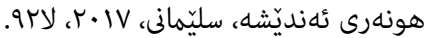

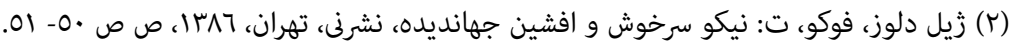
(3) Michel Foucault, the order of things- an archeology of the human sciences, translation of les mots et les choses, pantheon books, new york, 1971, p29.

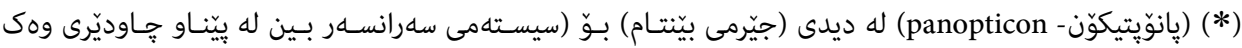

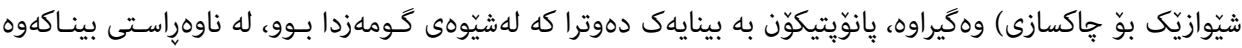

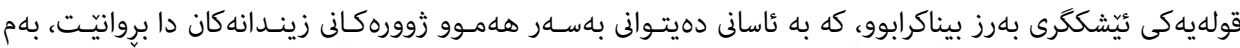

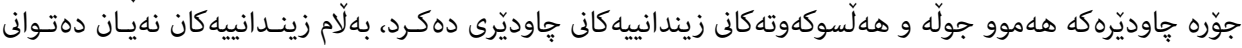

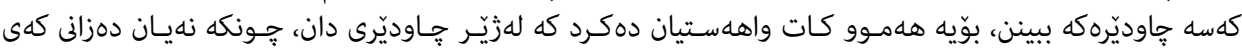

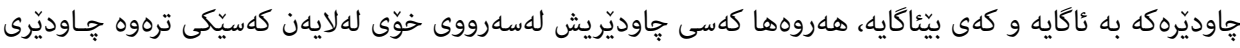

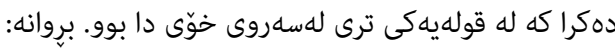
(Michel Foucault, Discipline and Punish (The Birth of the Prison), Translated from the French by: Alan Sheridan, Vintage Books, New York, without date, p200).

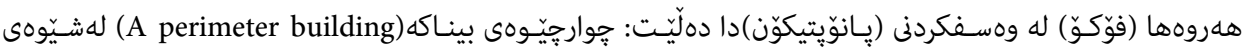

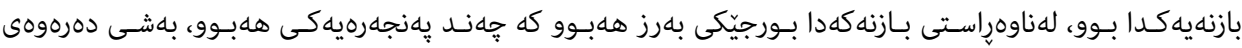

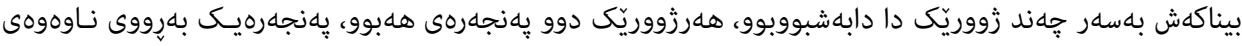




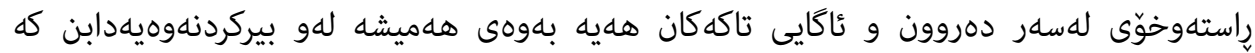

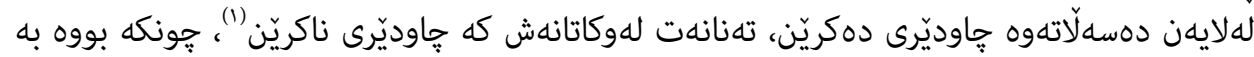

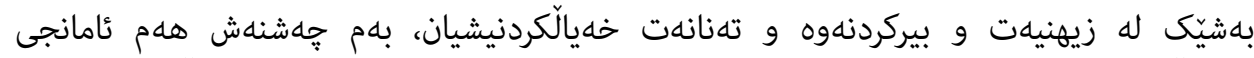

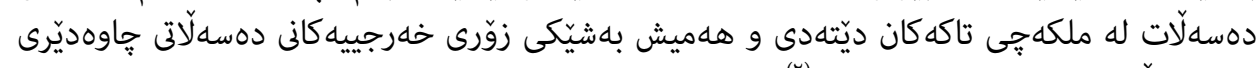

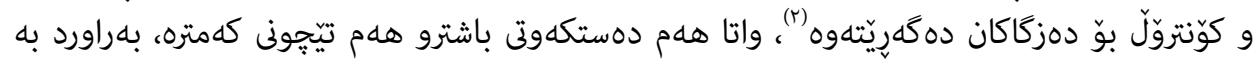

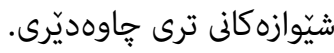

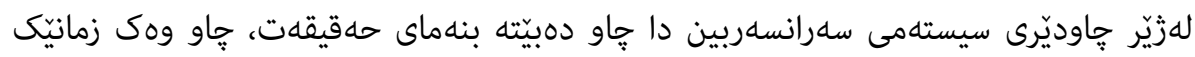

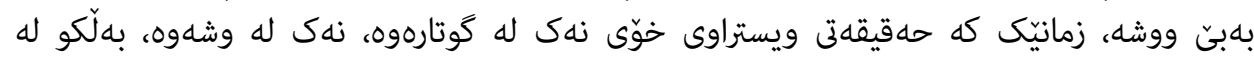

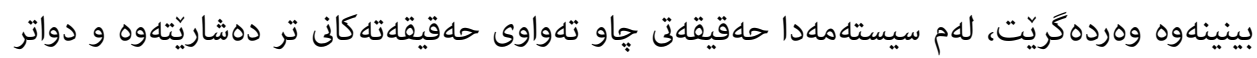

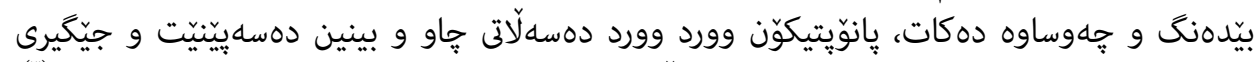

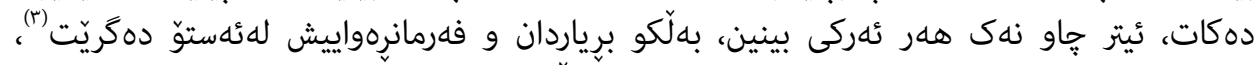

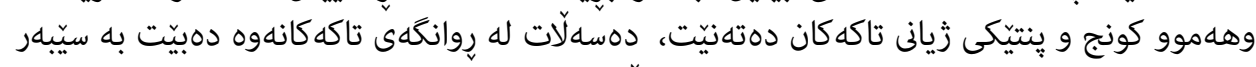

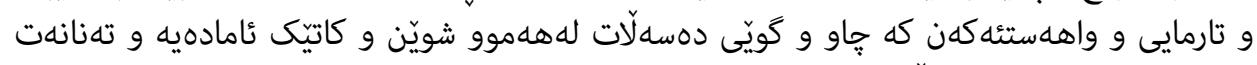

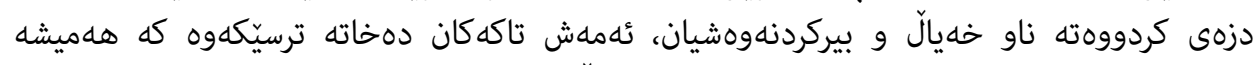

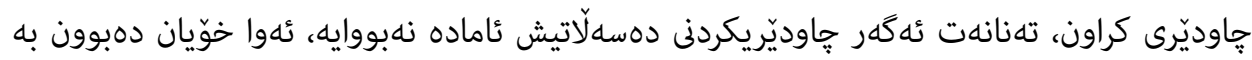

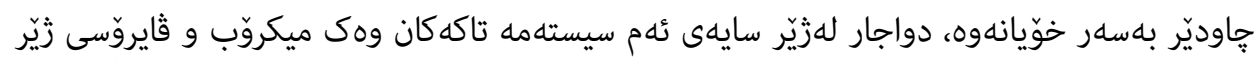

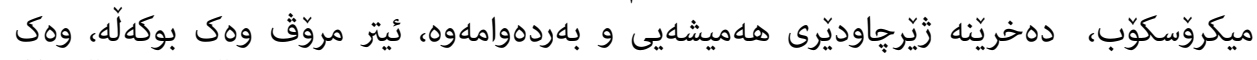

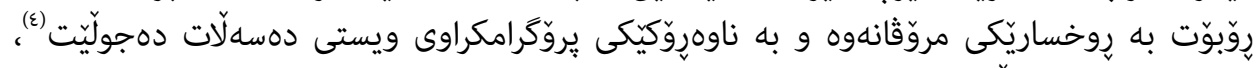

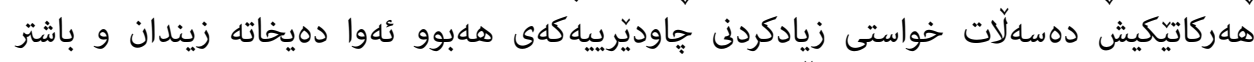

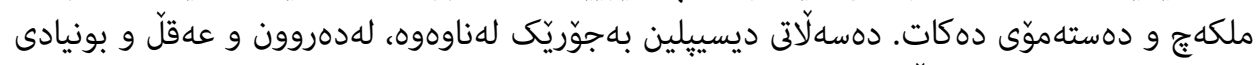

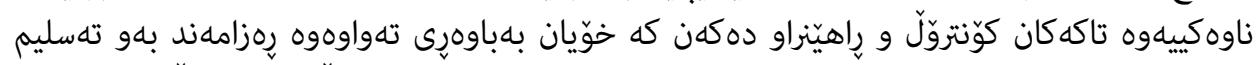

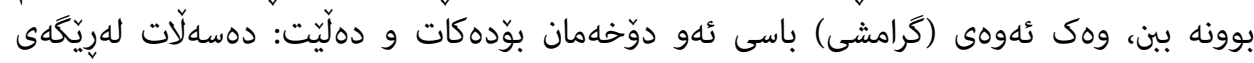

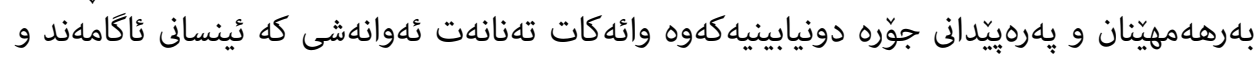

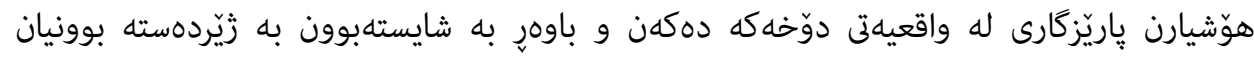

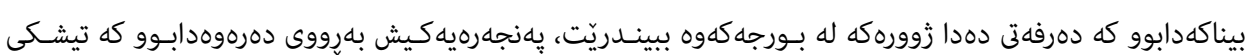

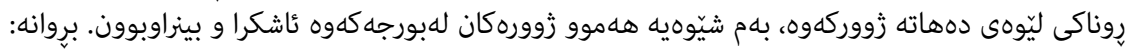
(Michel Foucault Power and Knowledge- Selected Interviews and Other Writings 1972-1977, Translated by: Colin Gordon, Leo Marshall John Mepham and Kate Soper, Pantheon Books, New York, 1980, p147)

(1) Michel Foucault, Discipline and Punish (The Birth o f the Prison), op.cit, p201.

(r) محمد صفار، تفكيك مفهوم القوة عند ميشيل فوكو - إعادة فتح الملف الإيرانى، مكتبة الاسكندرية، الاسكندرية-

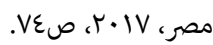

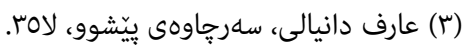

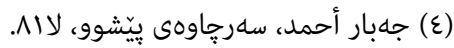




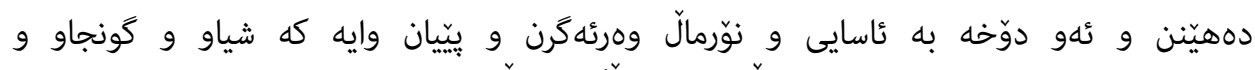

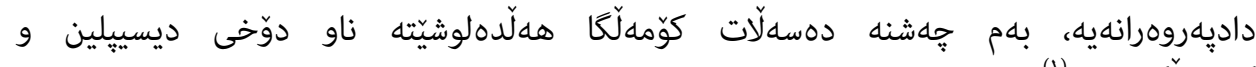

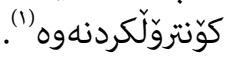

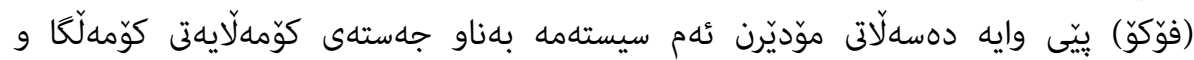

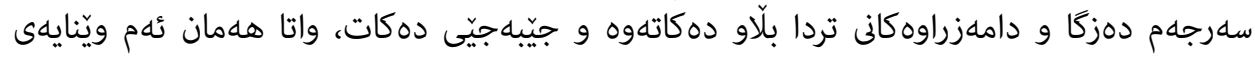

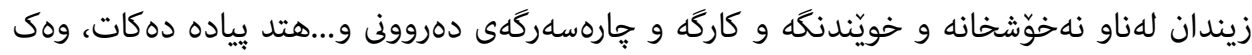

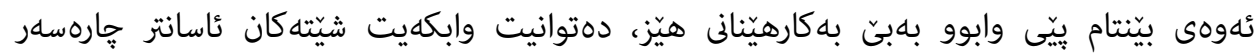

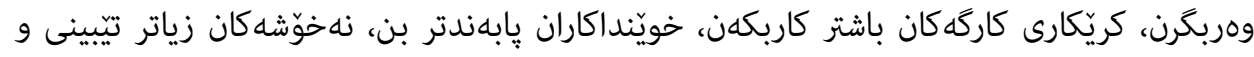

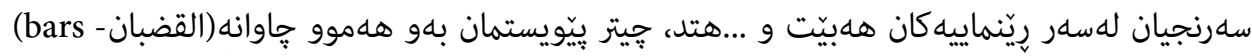

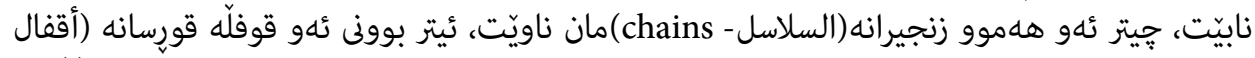

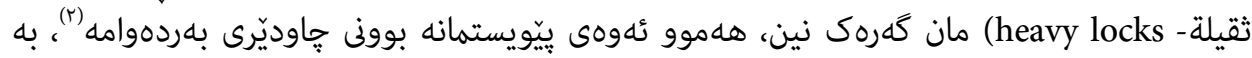

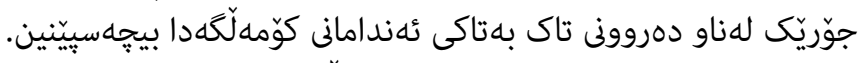

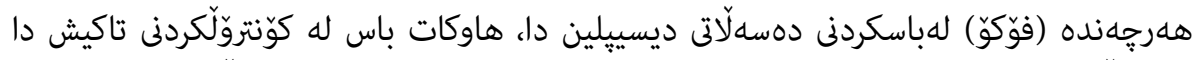

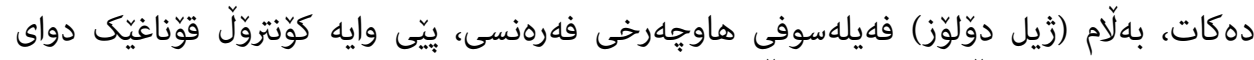

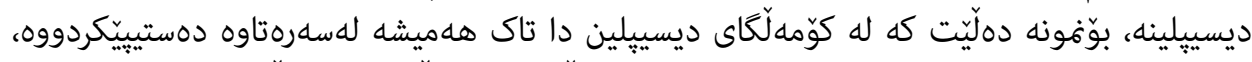

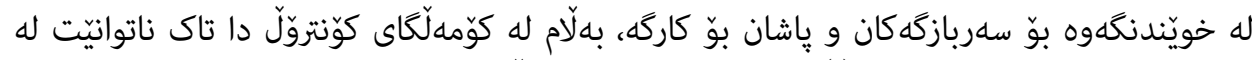

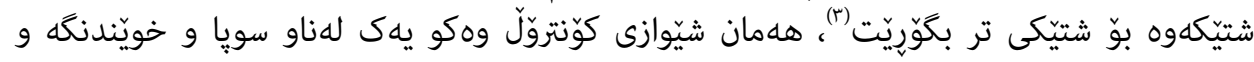

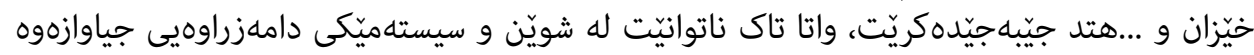

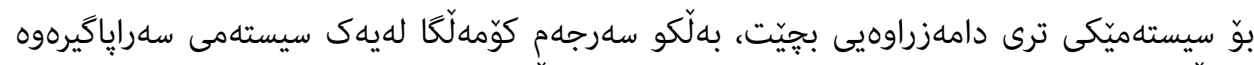

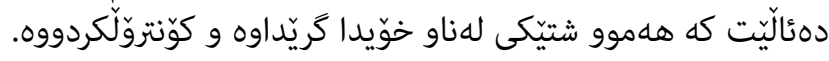

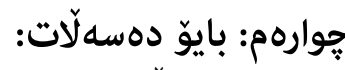

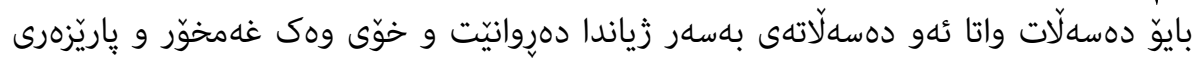

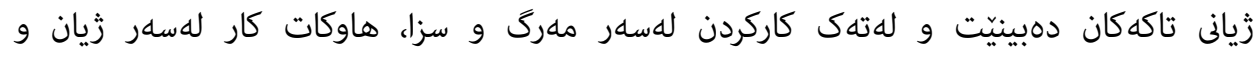

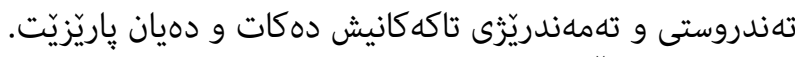

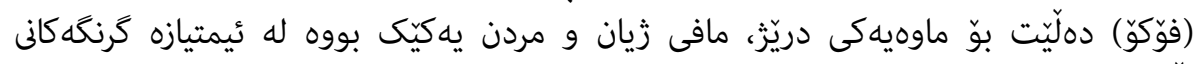

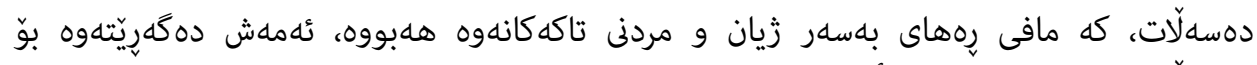

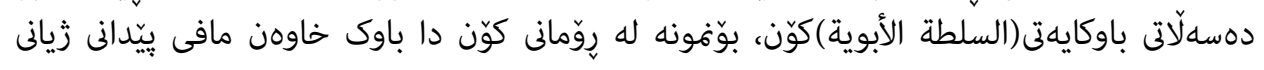

(1) carl boggs, the tow revolutions(Gramsci and the dilemmas of western Marxism), south end press, U.S.A, 1984, p199.

(2) Michel Foucault, Discipline and Punish (The Birth of the Prison), op.cit, p202.

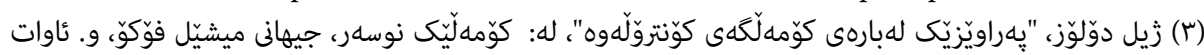

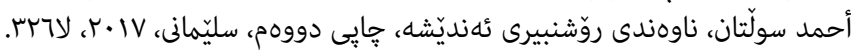




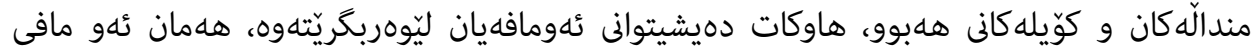

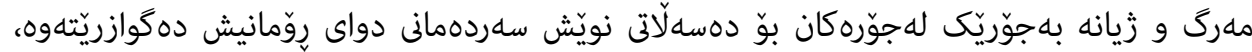

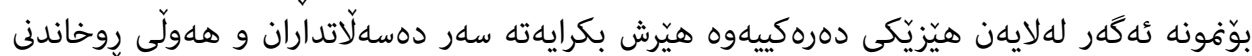

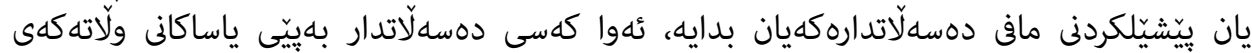

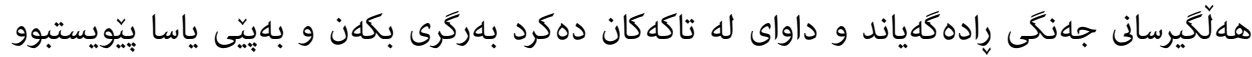

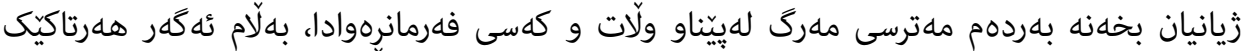

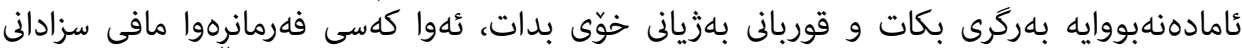

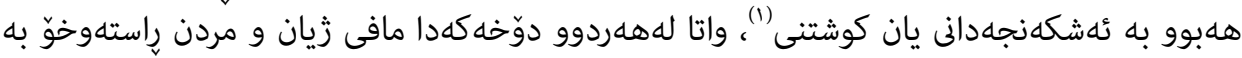

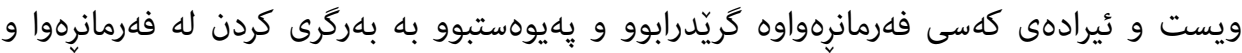

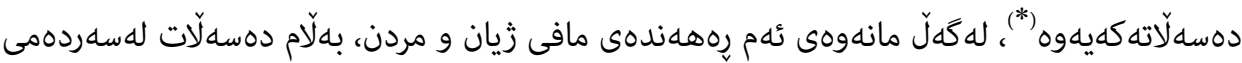

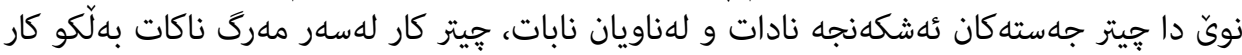

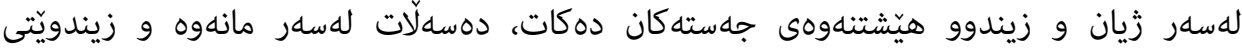

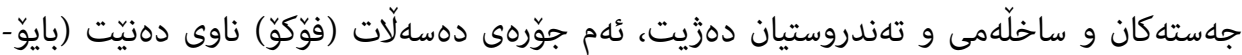

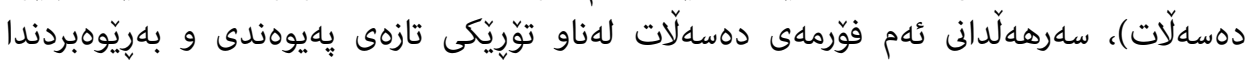

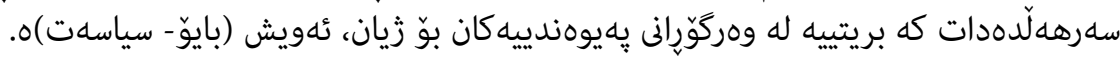

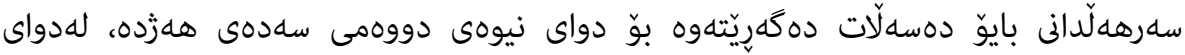

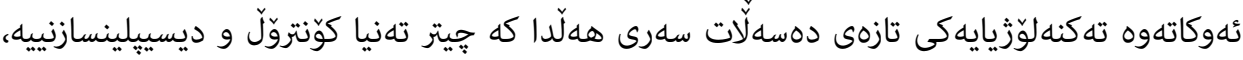

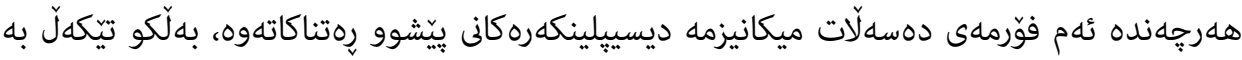

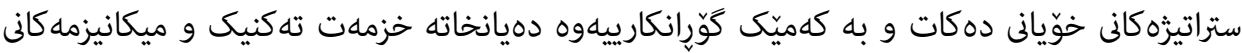

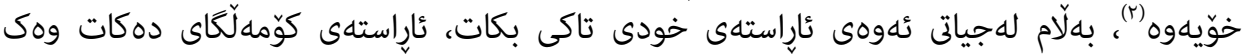

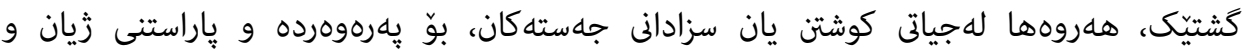

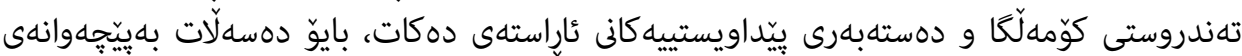

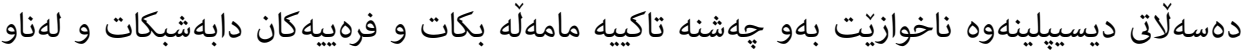

(1) Michel Foucault, the history of sexuality- vol 1, op.cit, p135.

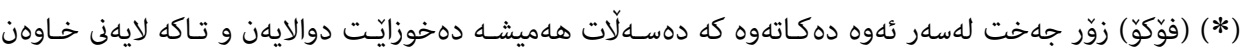

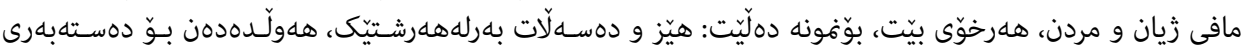

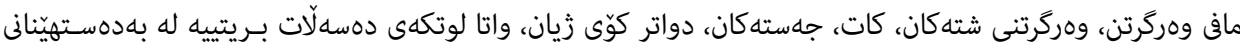

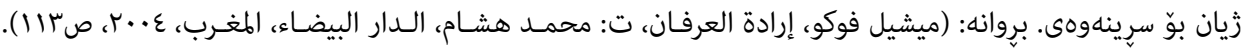

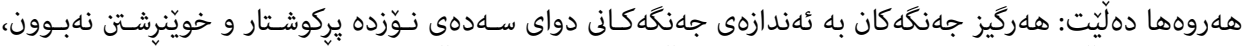

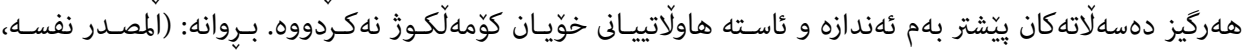

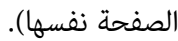

(2) Michel Foucault, Society Must Be Defended- Lectures At The College De France 1975-1976, op.cit, p242. 
بونياده تاككهراييهكاندا بيانتوينيّتهوه و ئهكهر يابهندى ئهو سيستهمه تاكسازييه ديسييلينكارهش

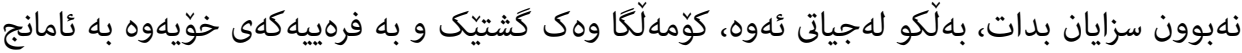

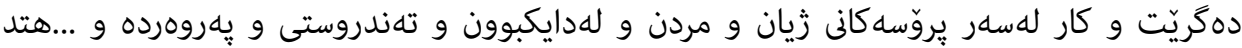

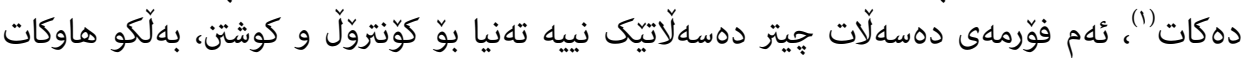

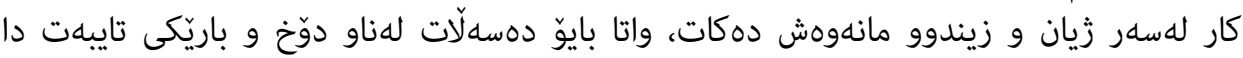

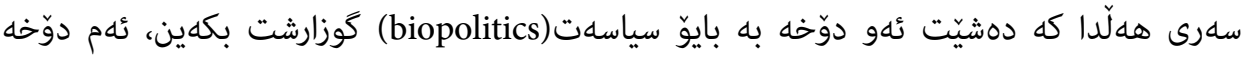

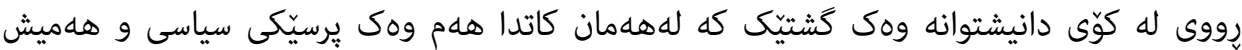

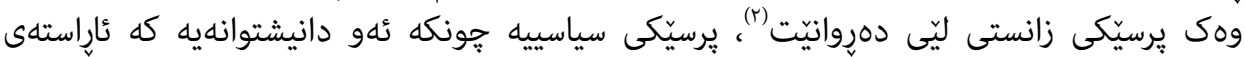

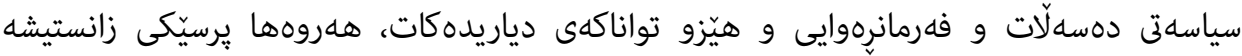

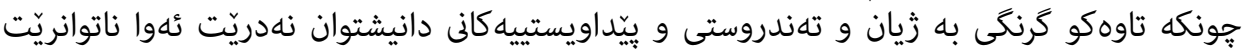

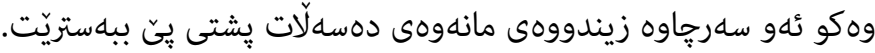

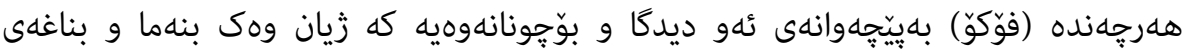
سياسهت دهزانن، تهنانهت له مهوداى كارى رِهنه

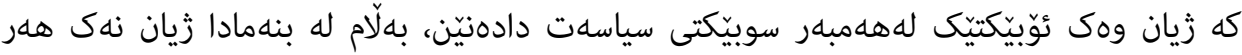

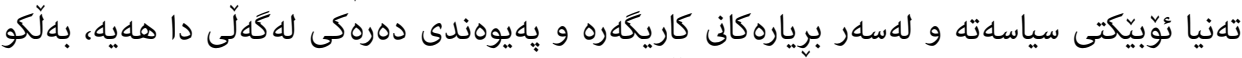

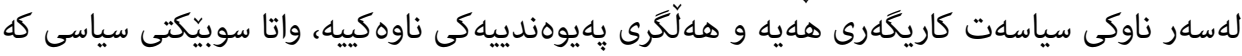

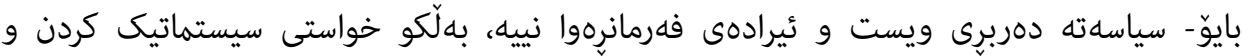

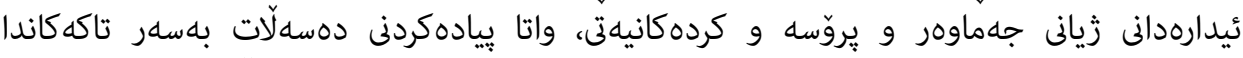

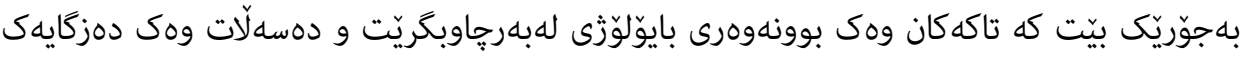

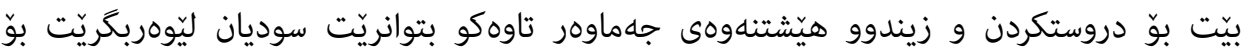

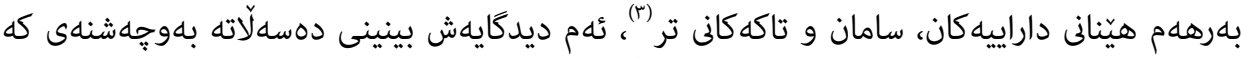

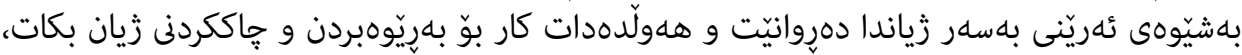

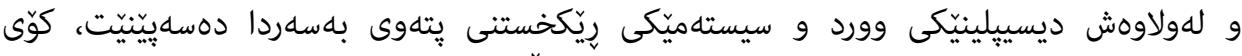

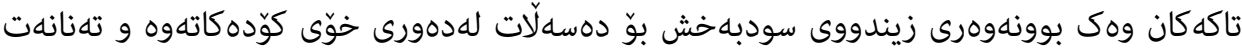

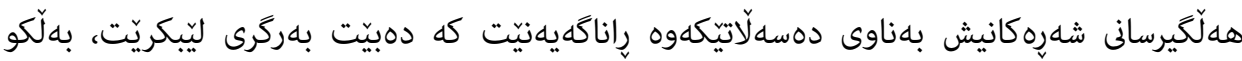

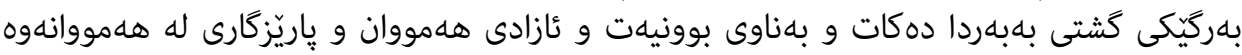

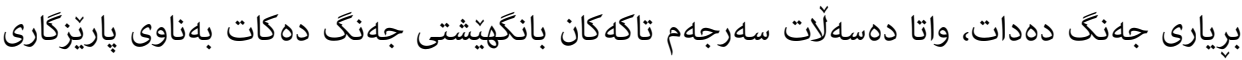

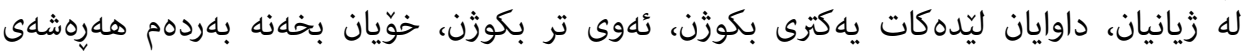

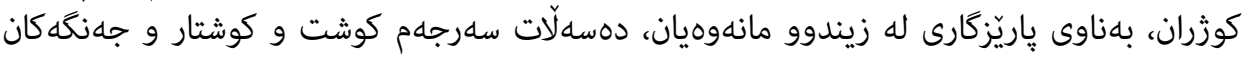

(1) ibid, pp242-243.

(2) ibid, p245.

(r) ميشيل فوكو، تئاتر فلسفه، منبع يِيشين، ص ص •1919 


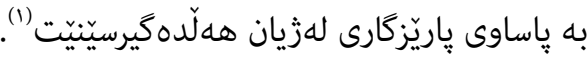

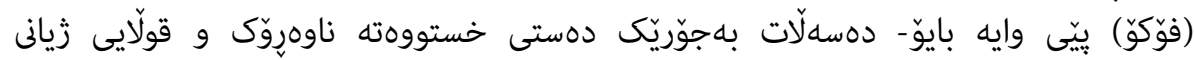

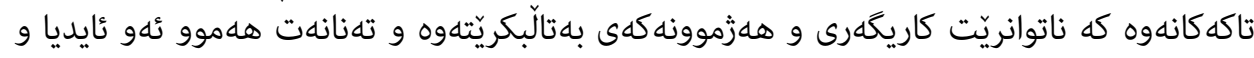

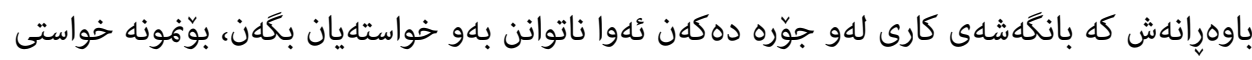

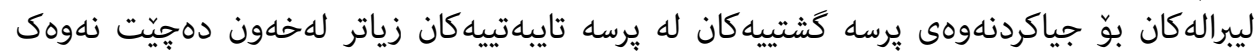

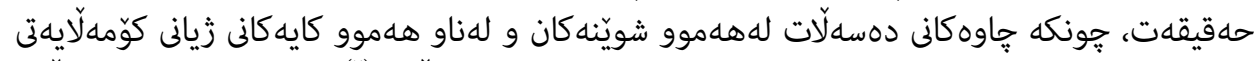

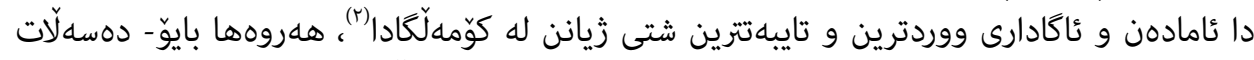

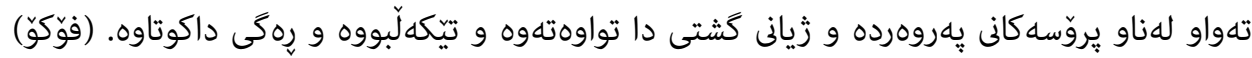

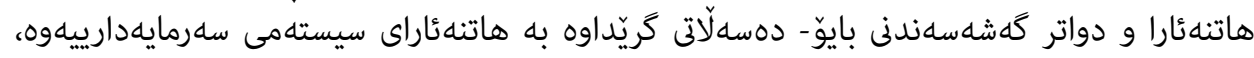

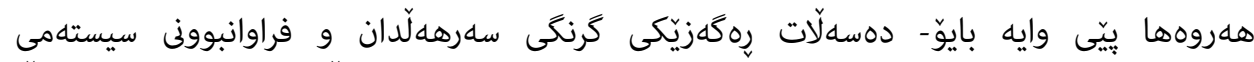

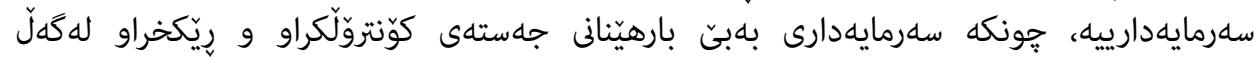

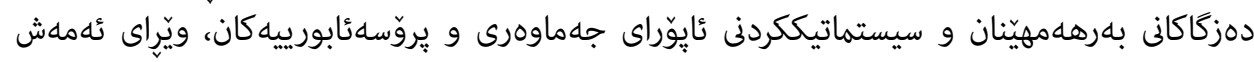

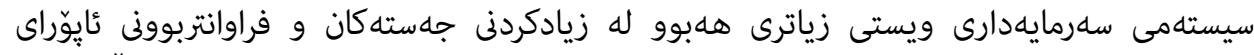

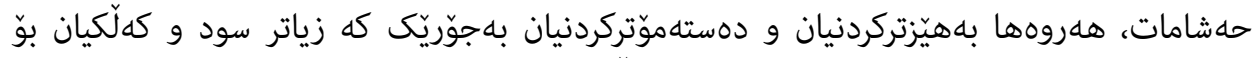

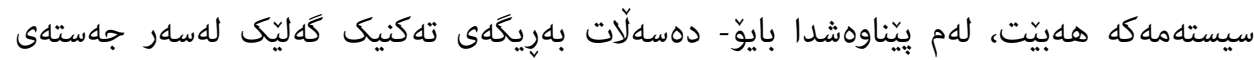

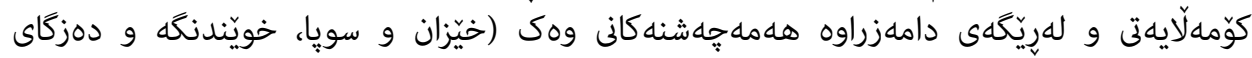

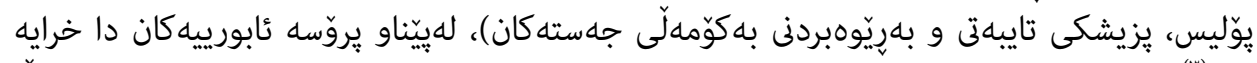

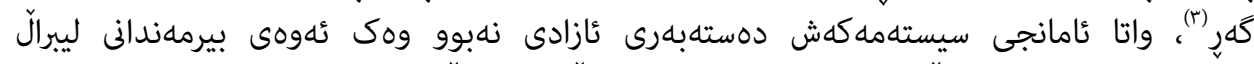

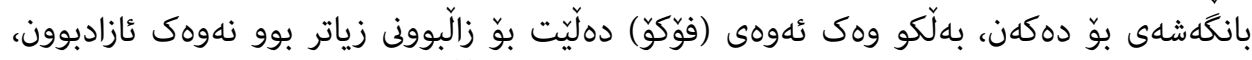

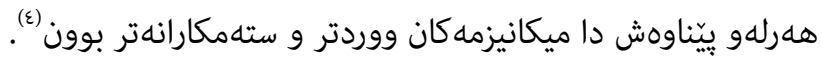

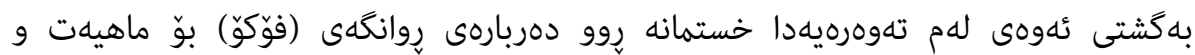

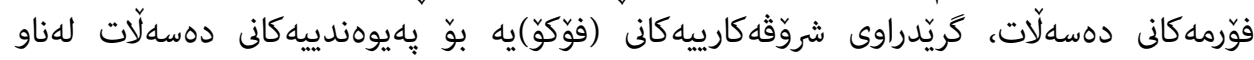

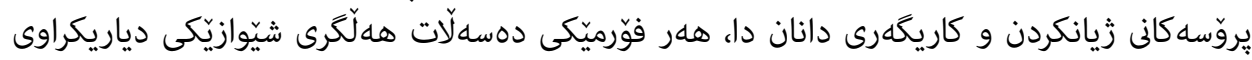

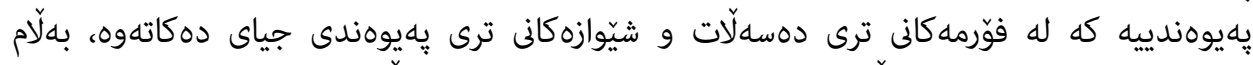

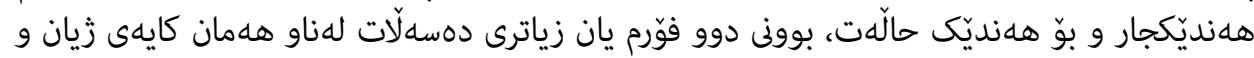

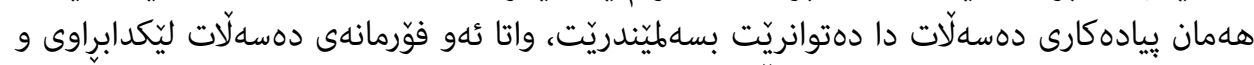

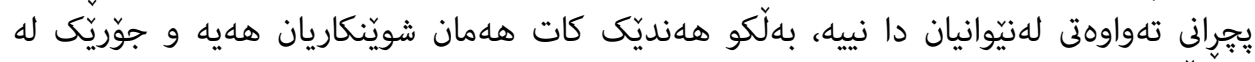

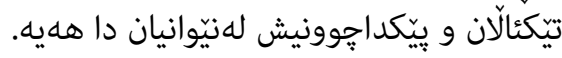

(1) Michel Foucault, the history of sexuality- vol 1, op.cit, p136.

(r) ئهييوب كهريمى، سهرجاوهى يِيشوو، لآT.

(3) Michel Foucault, the history of sexuality- vol 1, op.cit, pp140- 141.

(4) Lisa Downing, The Cambridge Introduction to Michel Foucault, CAMBRIDGE UNIVERSITY PRESS, New York, 2008, p76. 


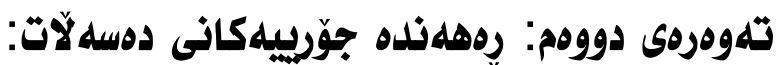

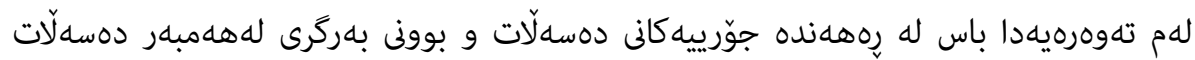

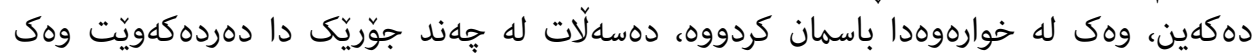

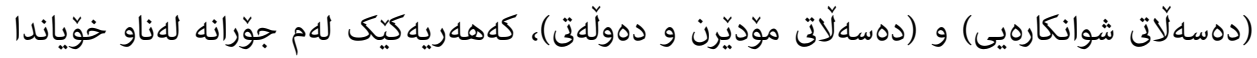

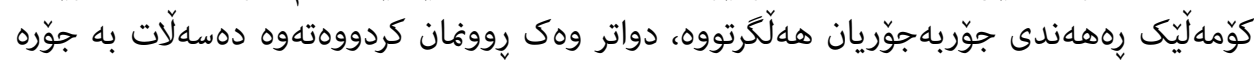

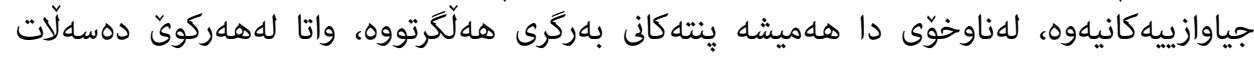

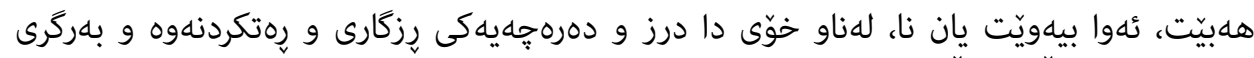

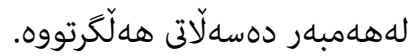

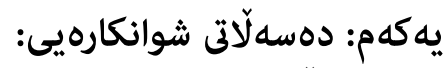

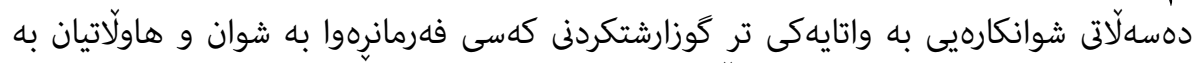

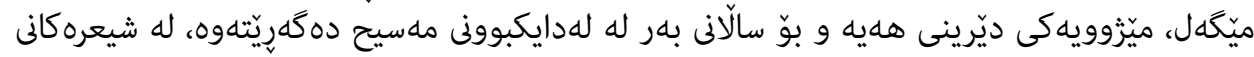

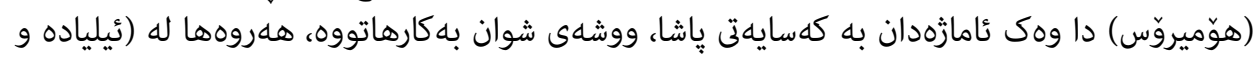

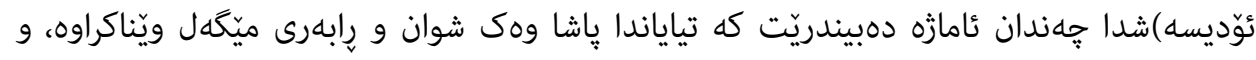

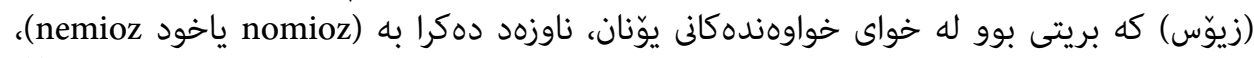

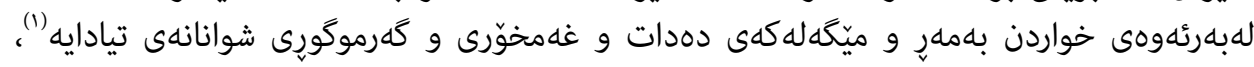

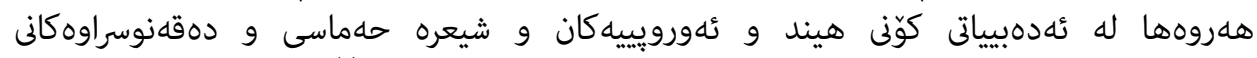

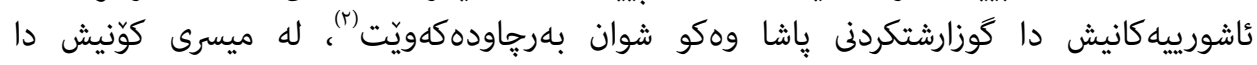

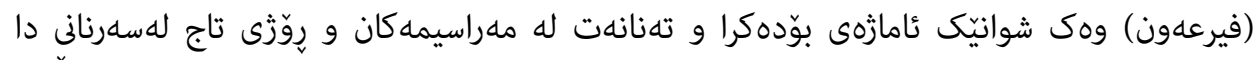

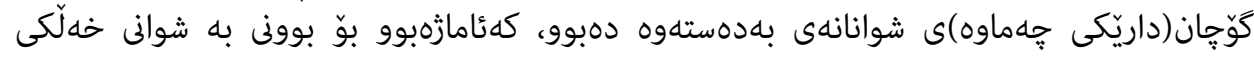

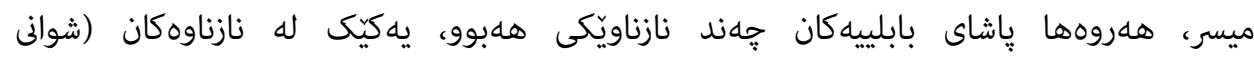

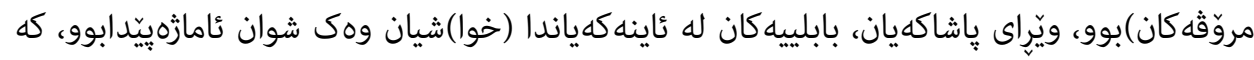

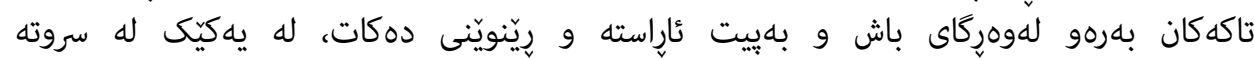

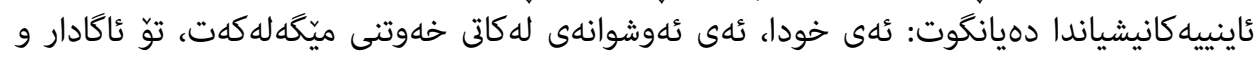

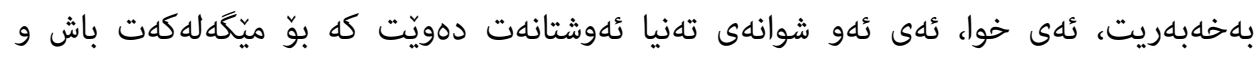

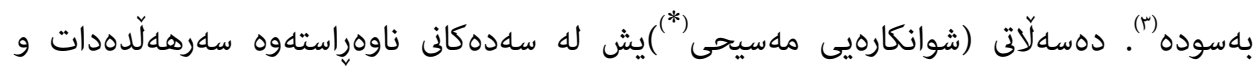

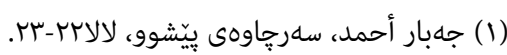

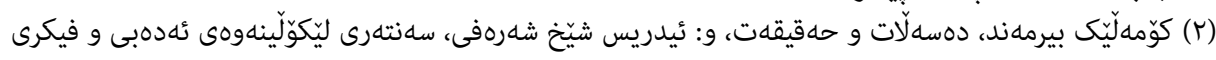

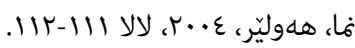

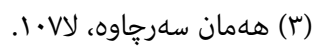

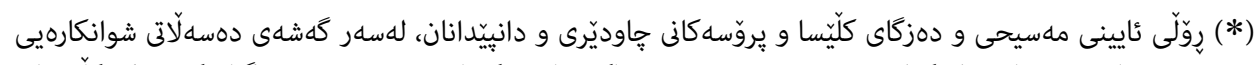

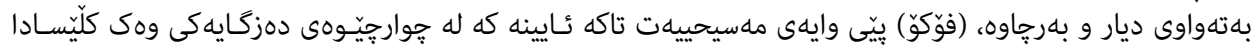




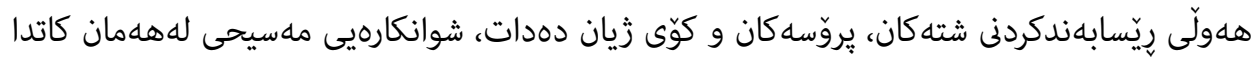

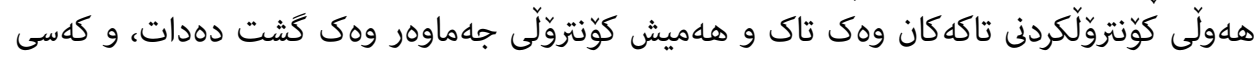

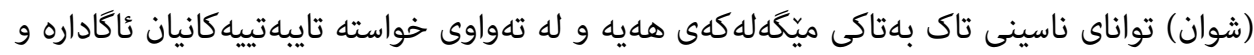

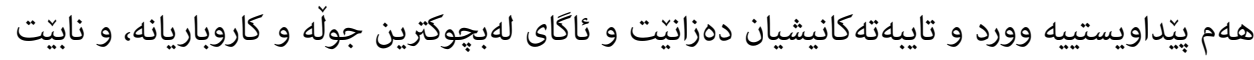

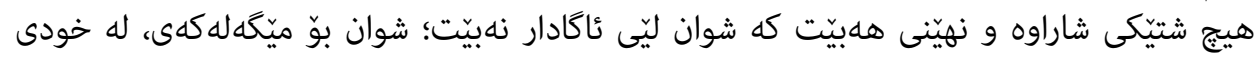

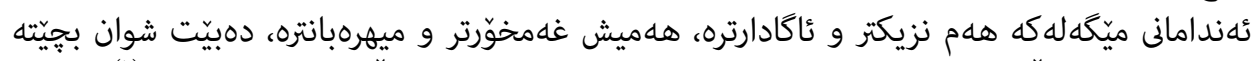

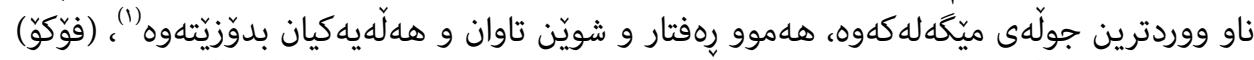

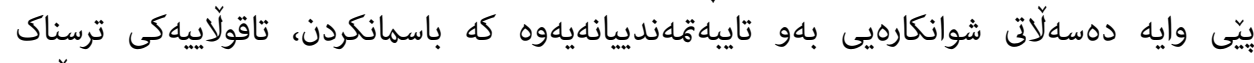

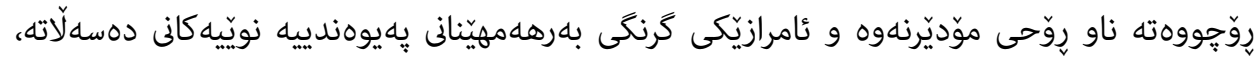

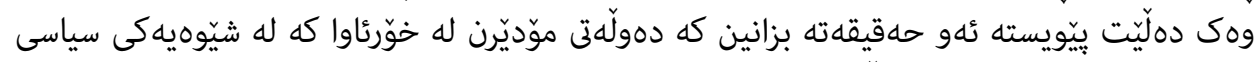

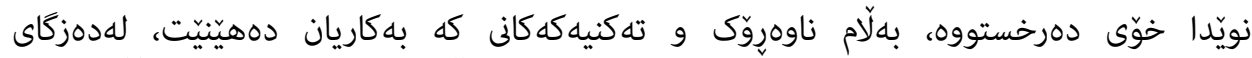

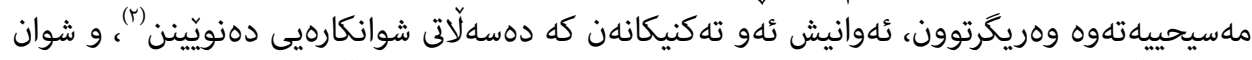

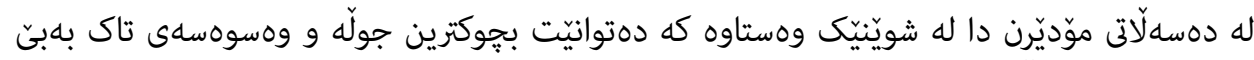

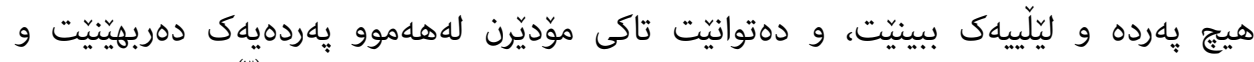

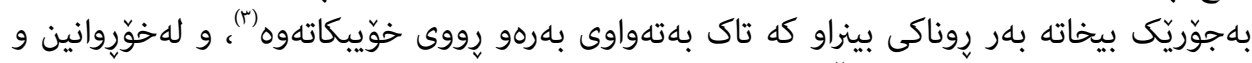

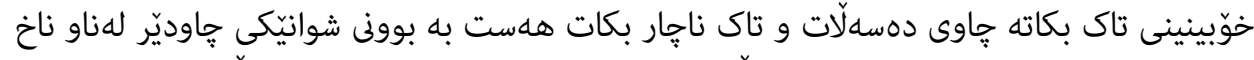

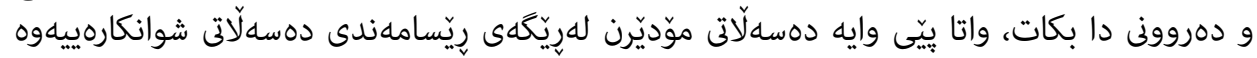

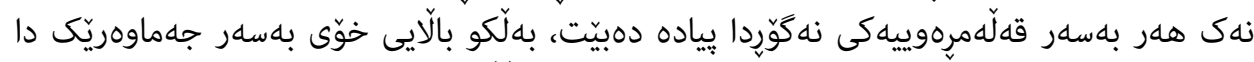

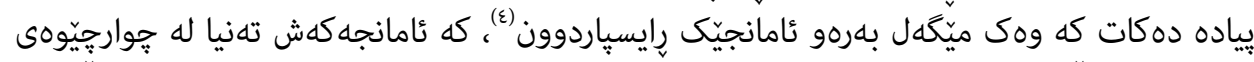

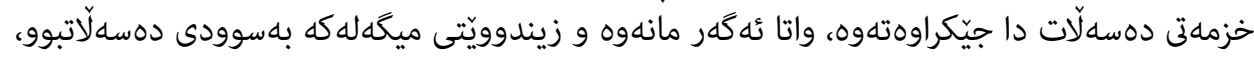

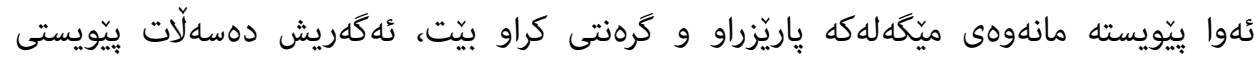

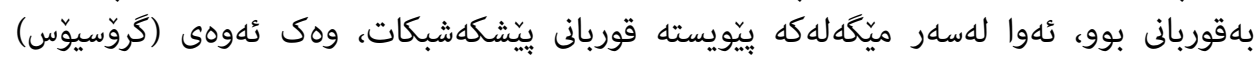

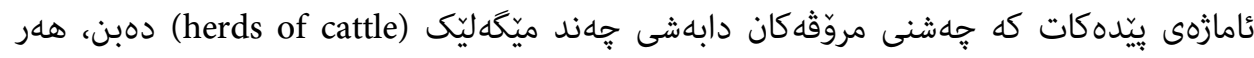

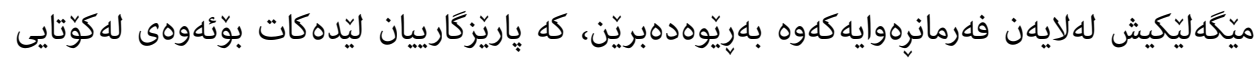

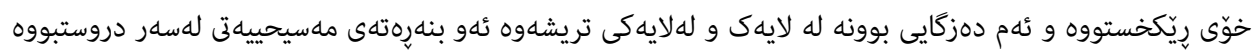

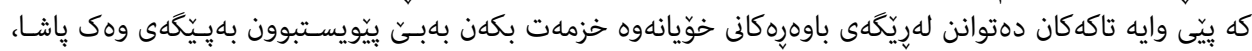

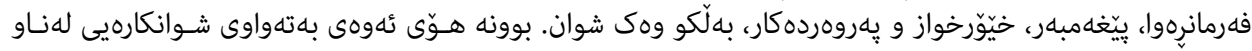

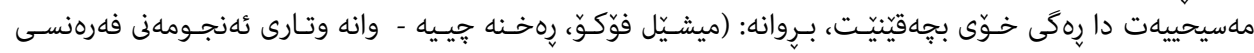

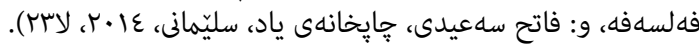

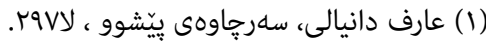
(2) Michel Foucault, critical inquiry- vol 8 - subject and power, op.cit, pp782-783.

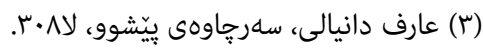

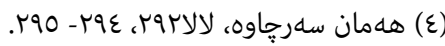




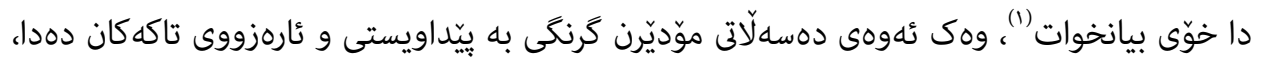

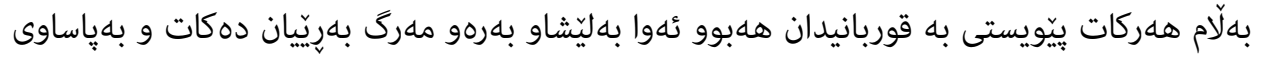

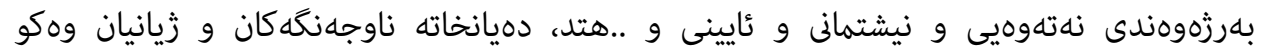
سهروهتى جهنگيى بوّخوّى دهبينيتيت.

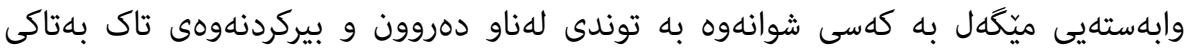

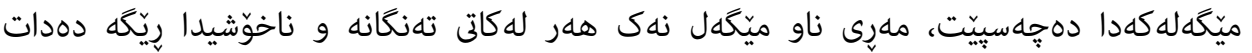

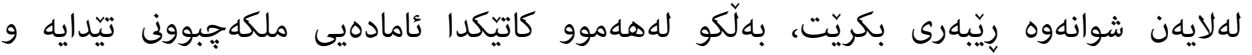

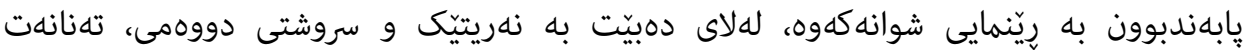

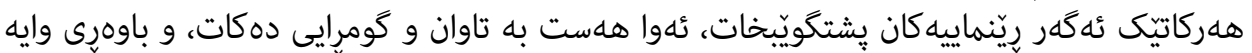

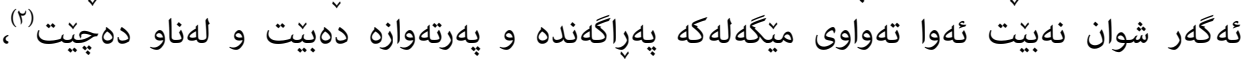

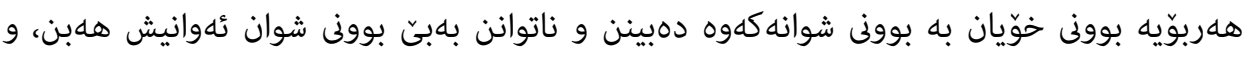

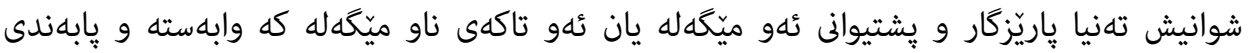

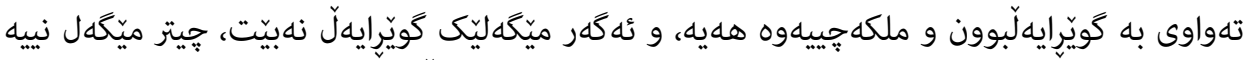

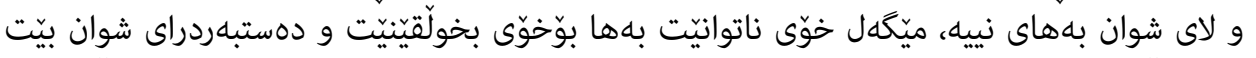

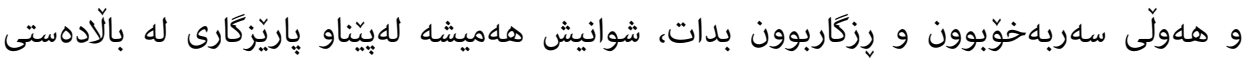

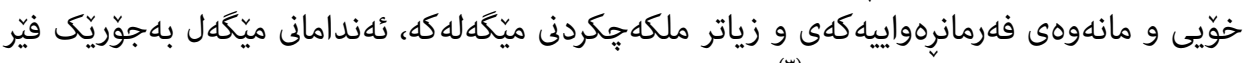

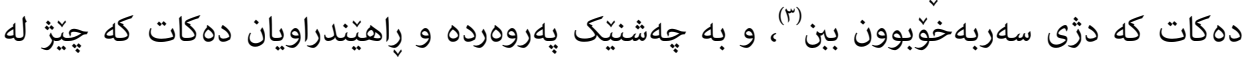
ملكهجى بيينن.

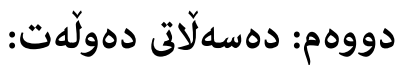

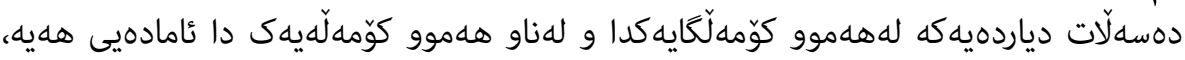

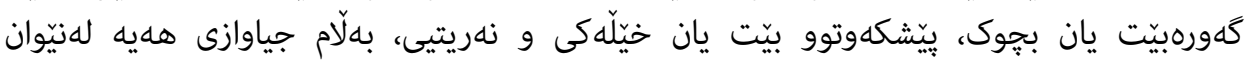

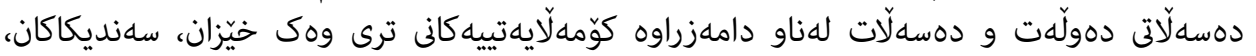

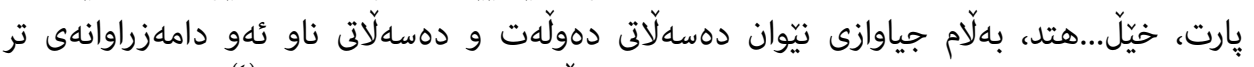

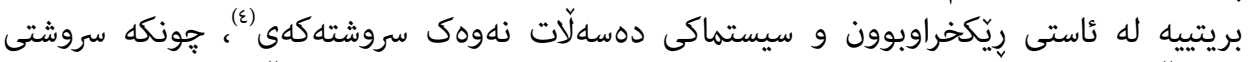

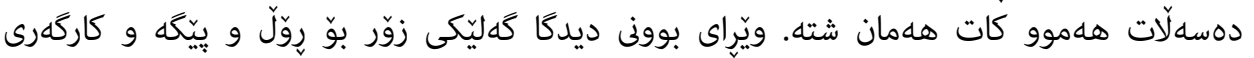

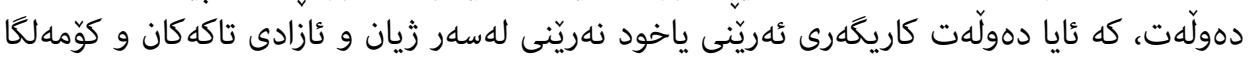

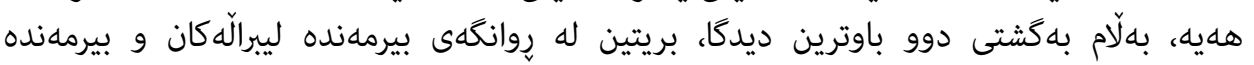

(1) Jean Jacques Rousseau, op.cit, p3. 


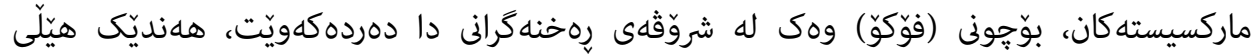

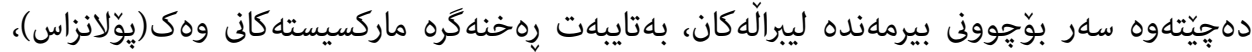

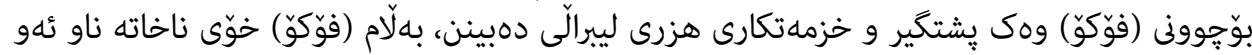

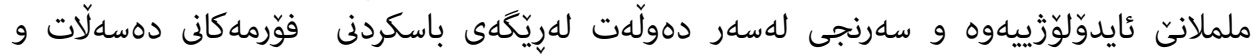

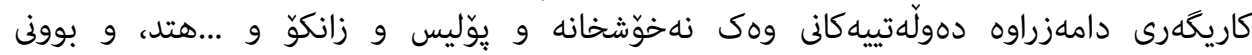

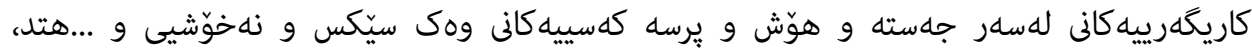

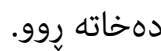

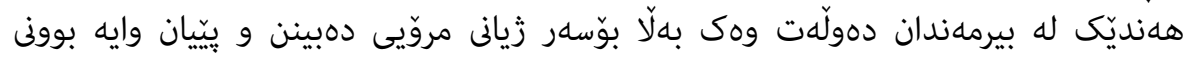

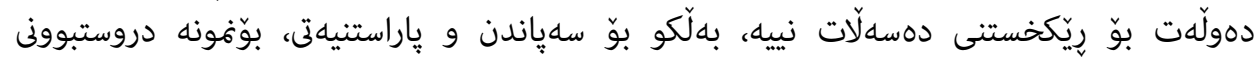

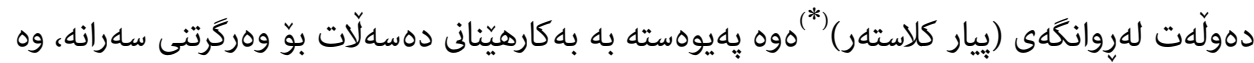

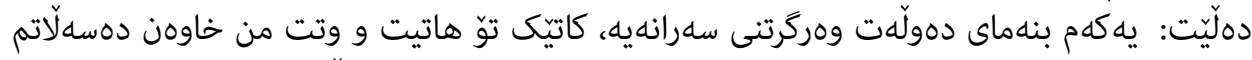

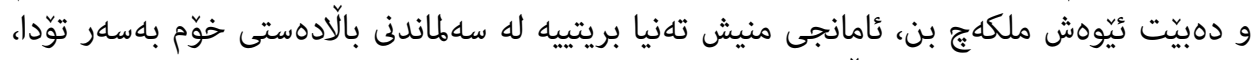

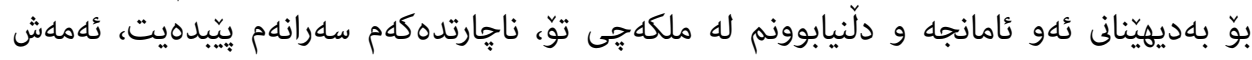

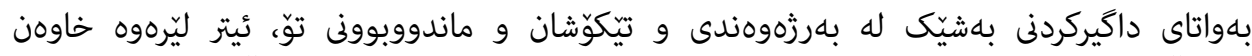

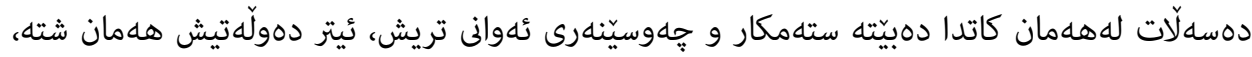

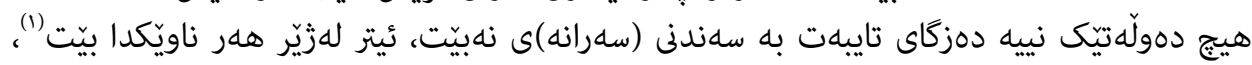

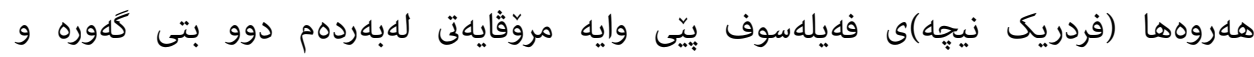

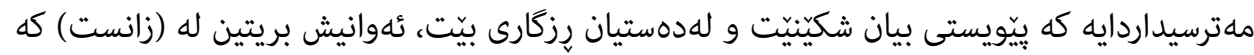

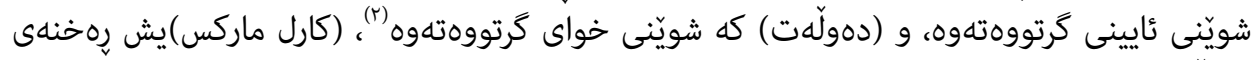

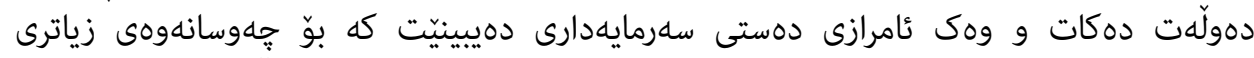

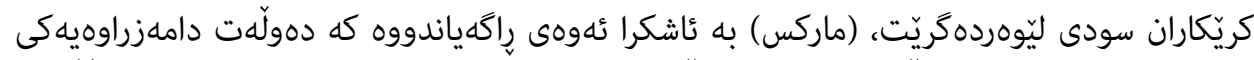

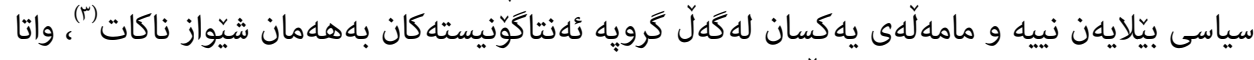

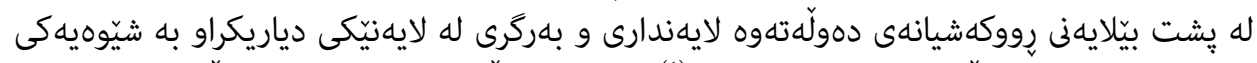

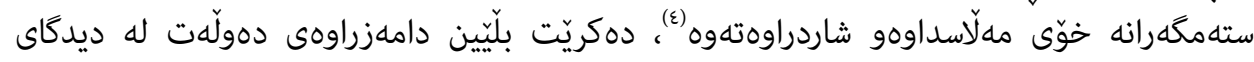

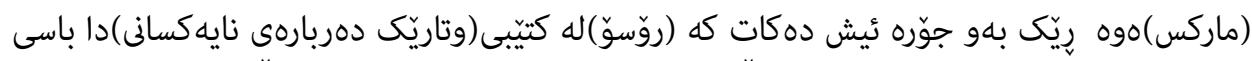

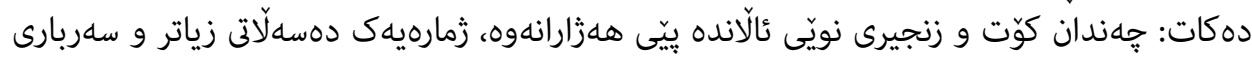

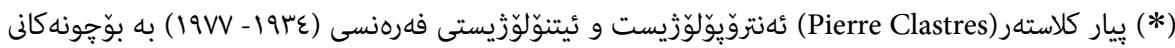

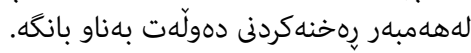

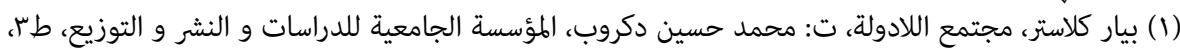

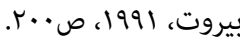

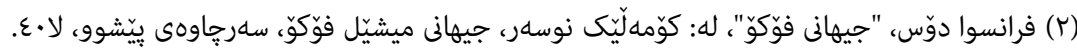

(3) Terry Eagleton, Why Marx Was Right, Yale University, London, 2011, p197.

(4) ibid, p199. 


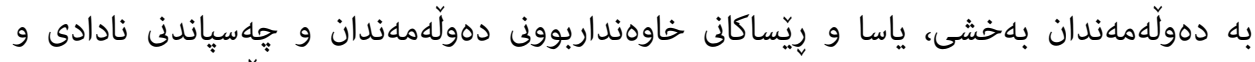

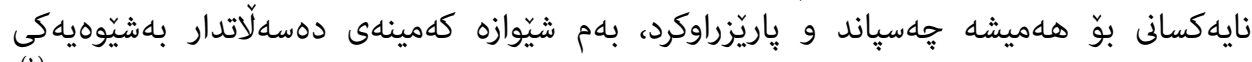

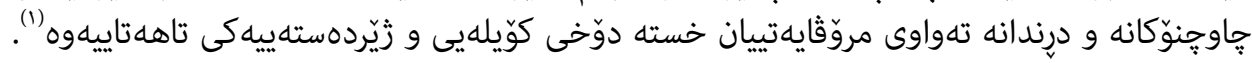

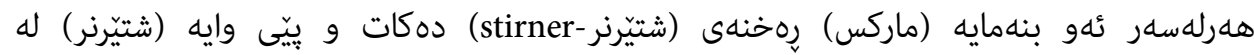

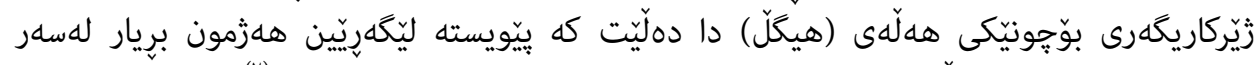

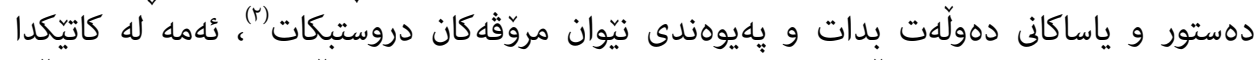

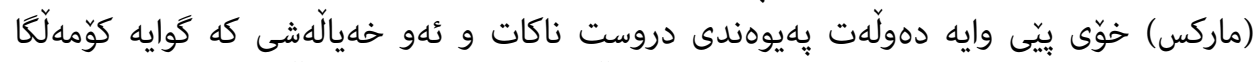

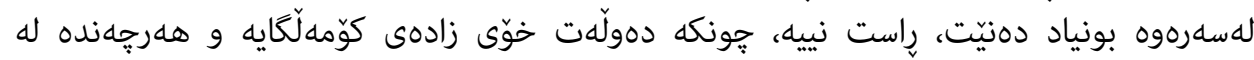

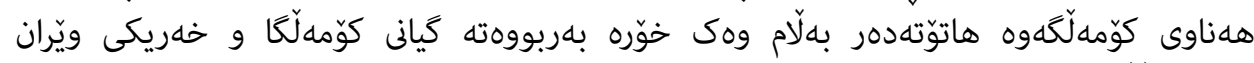

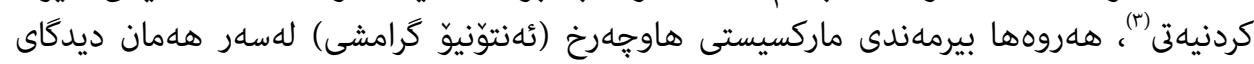

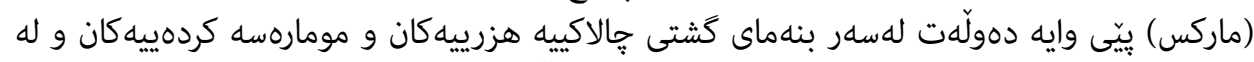

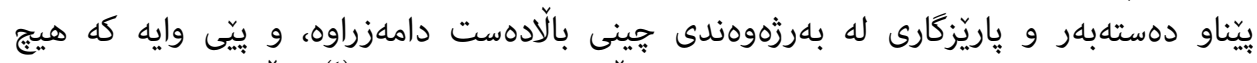

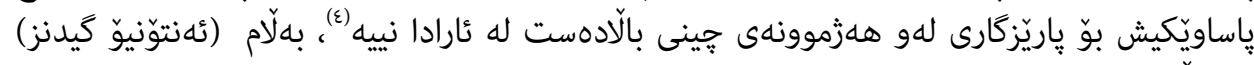

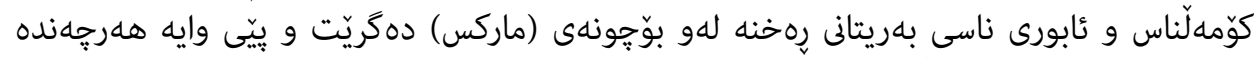

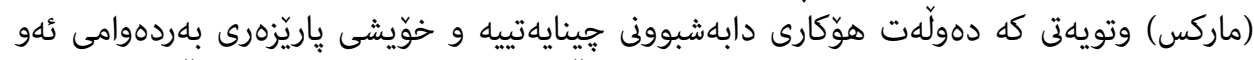

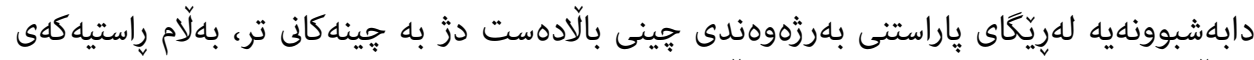

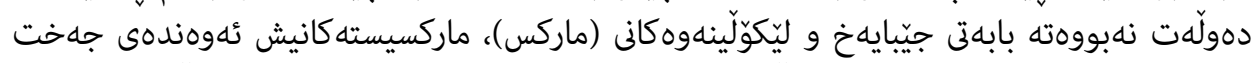

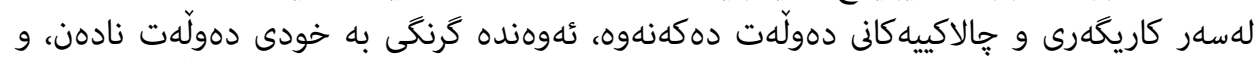

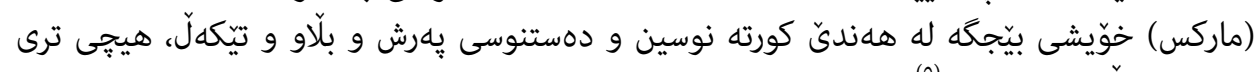

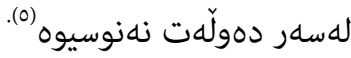

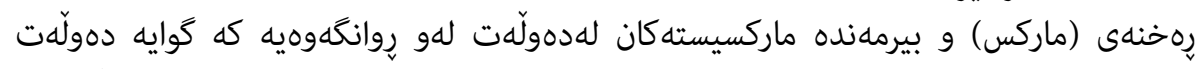

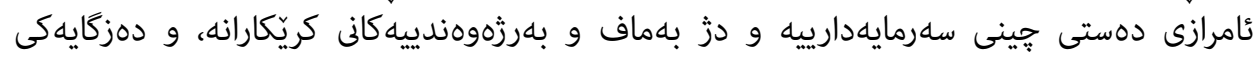

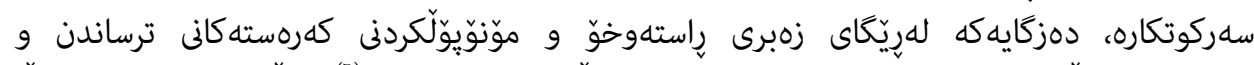

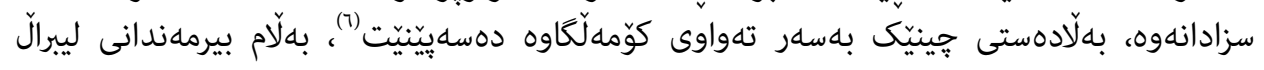

(1) ibid, p199.

(2) Karl Marx and Frederick Engels, collected works- volume 5, translated by: W. Lough and C. P. Magill, published by Lawrence \& Wishart, London, 1938, p173.

(3) Terry Eagleton, op.cit, pp201-202.

(ع) أندرو فنسنت، نظريات الدولة، ت: مالك أبوشهيوة و محمود خلف، دار الرواد، طرابلس- ليبيا، 997 ا، صساب.

(5) Anthony Giddens, sociology- a brief but critical introduction, published by Macmillan education LTD, Second edition, London, 1986, pp72-73.

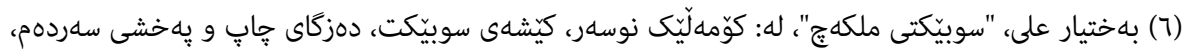

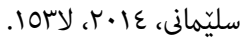




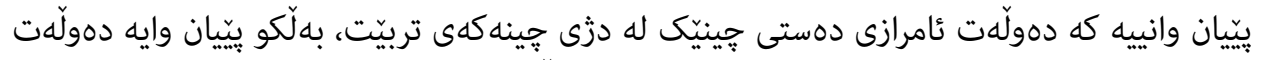

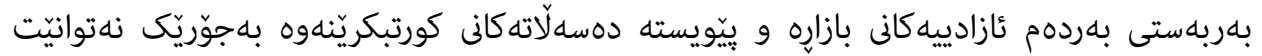

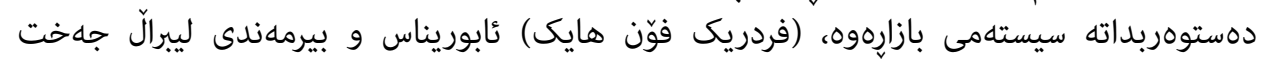

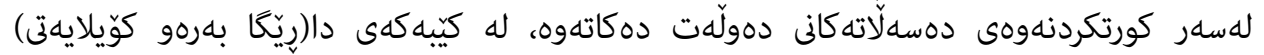

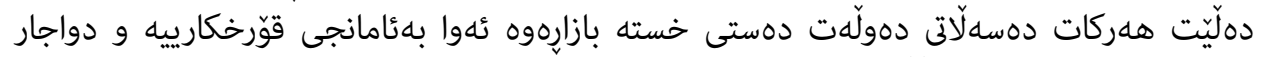

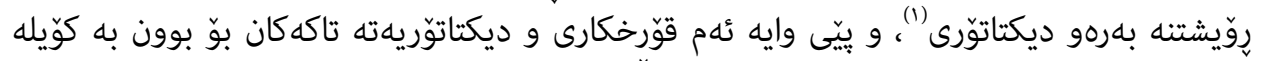

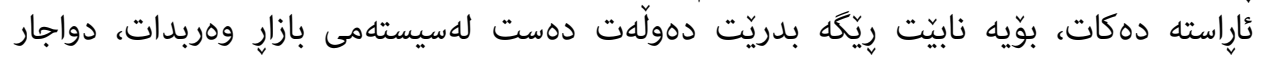

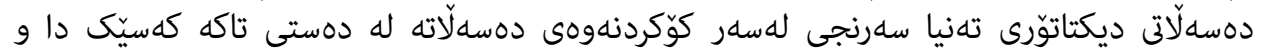

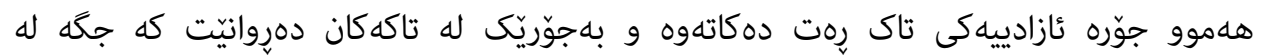

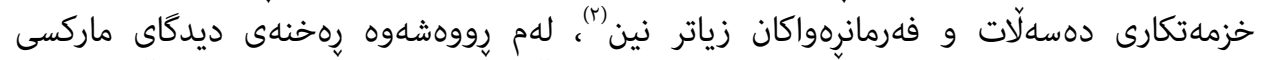

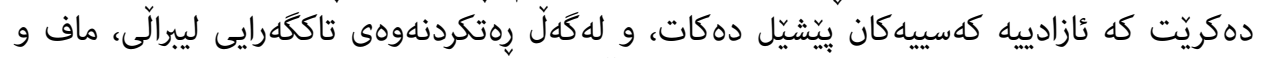

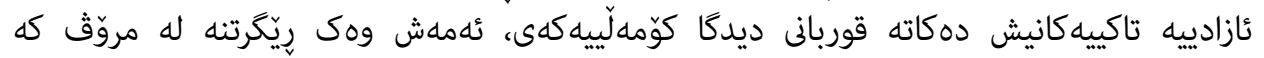

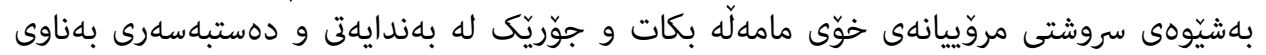

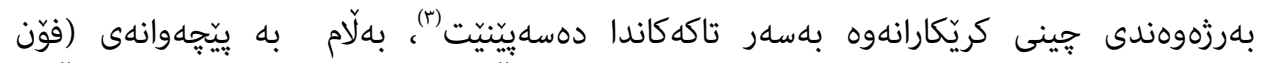

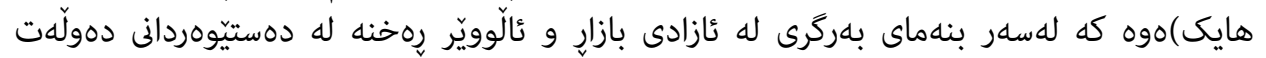

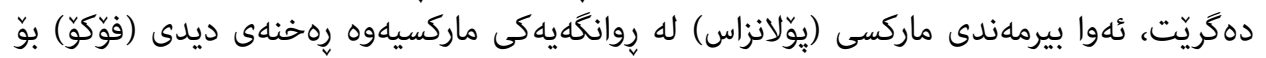

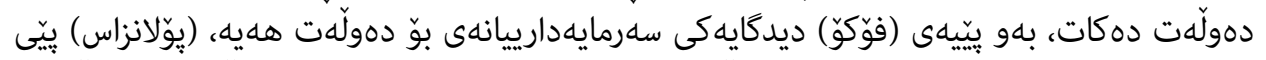

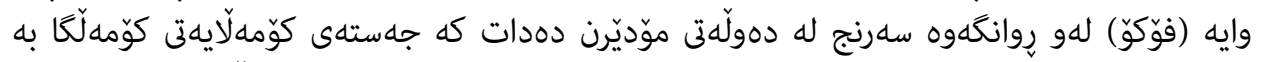

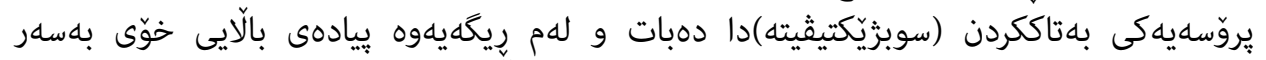

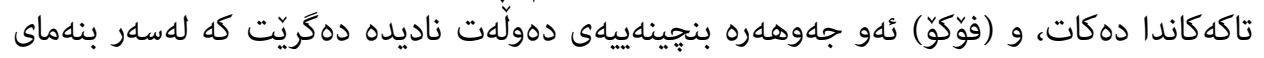

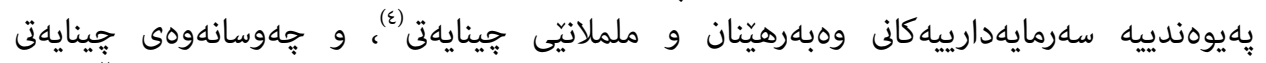

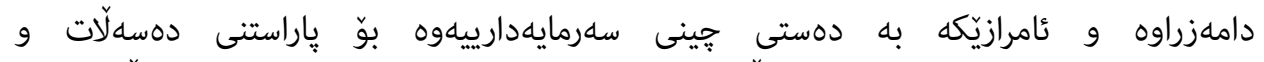

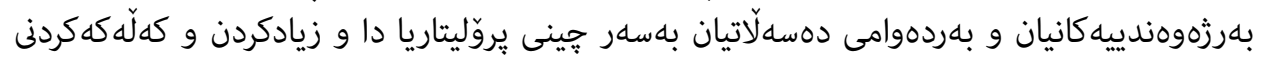

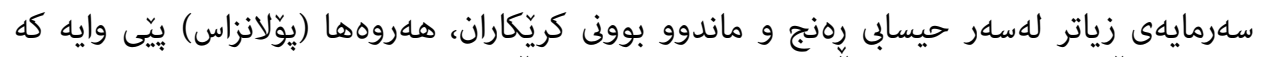

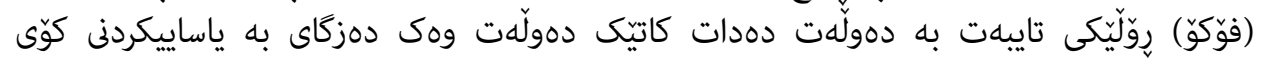

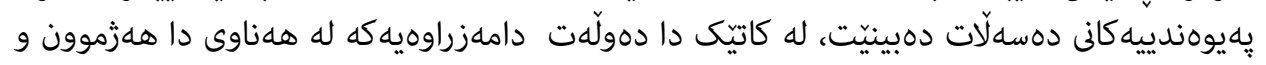

(1) F.A.Hayek, The Road To Serfdom, Rutledge, London and New York, 2006, pp92-93.

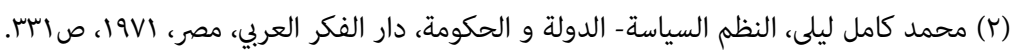

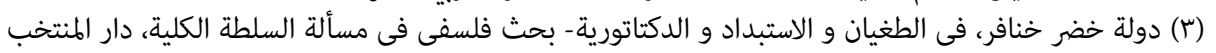

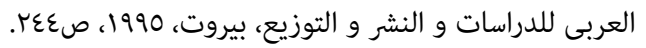

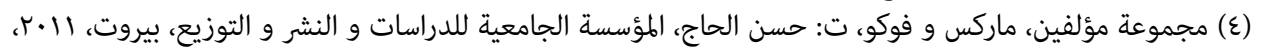




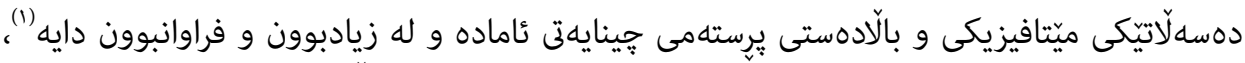

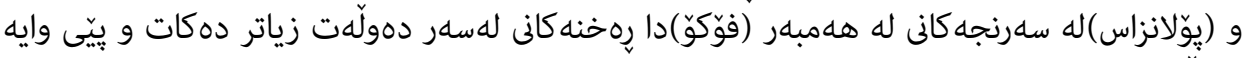

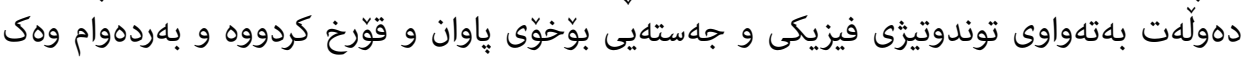

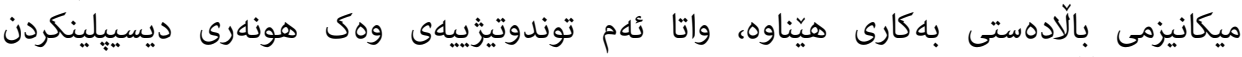

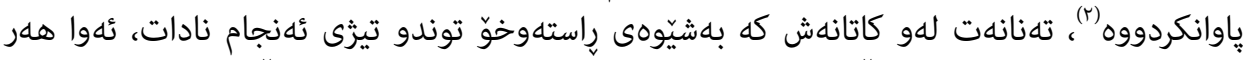

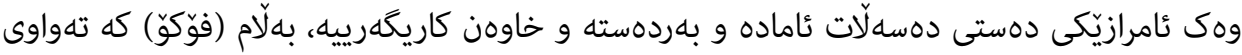

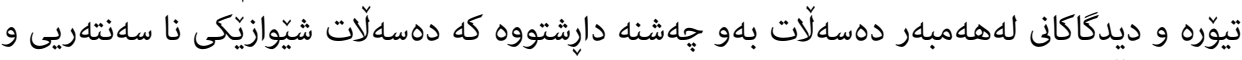

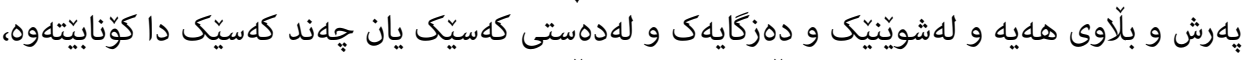

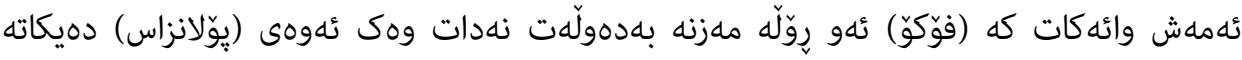

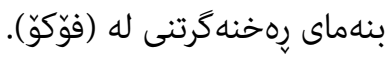

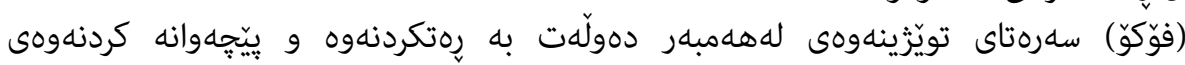

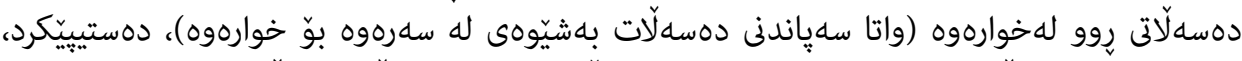

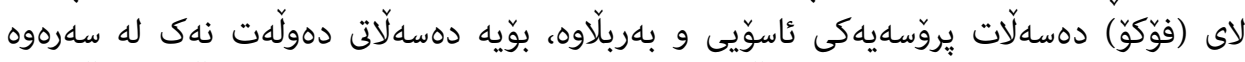

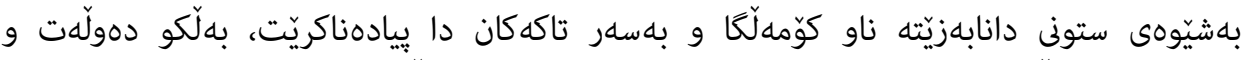

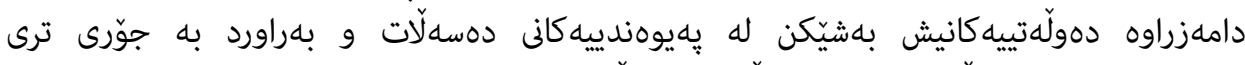

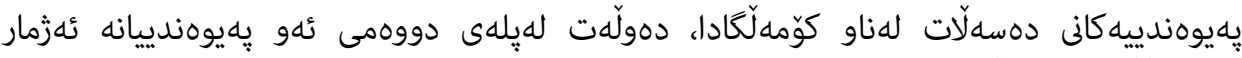

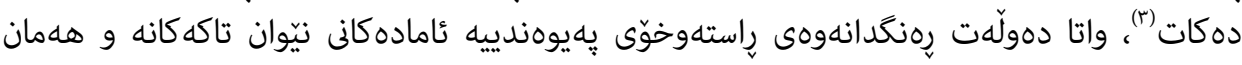

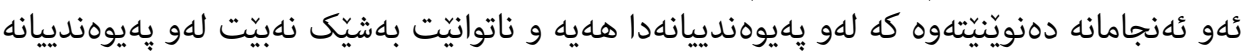

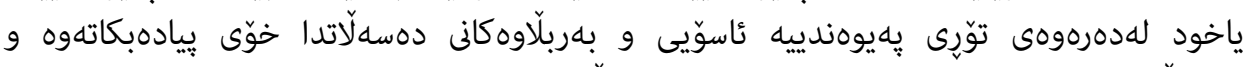

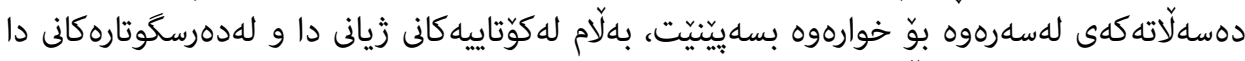

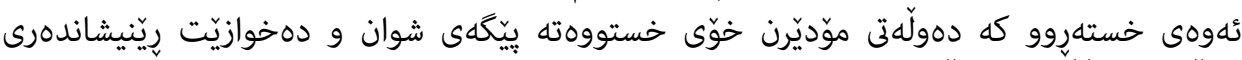

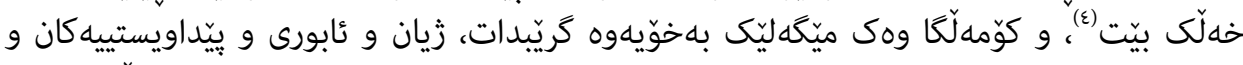

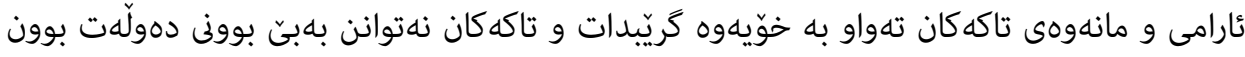

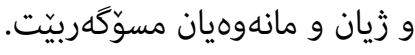

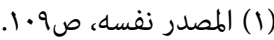

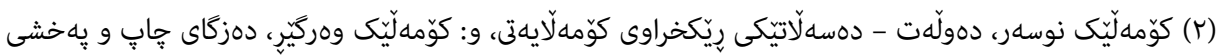

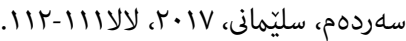

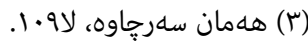

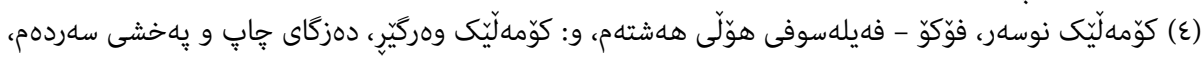

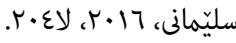




\section{سيّيهم: بهركرى لهههمبهر دهسه لَات:}

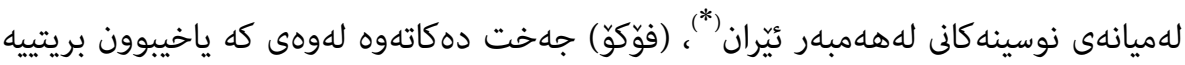

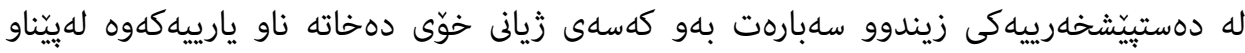

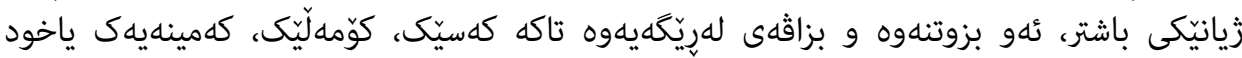

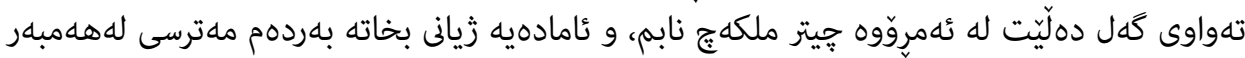

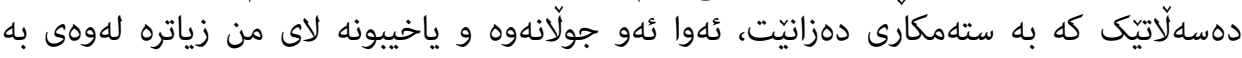

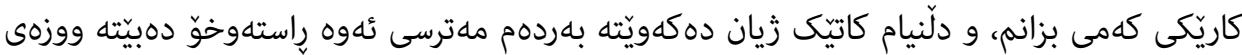

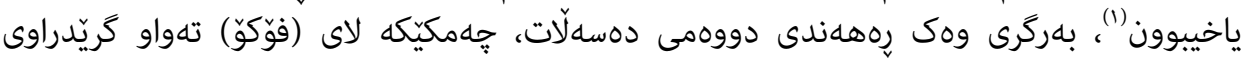

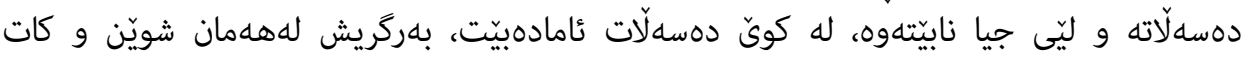

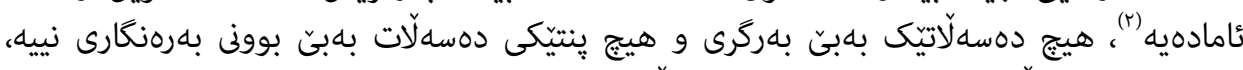

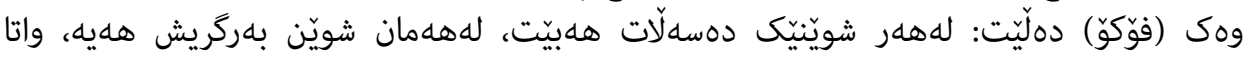

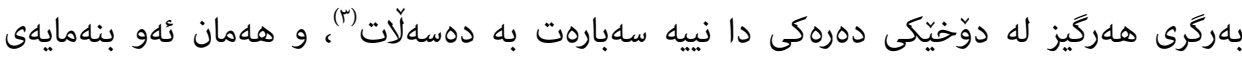

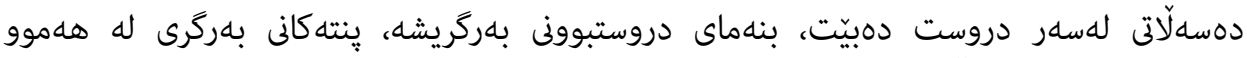

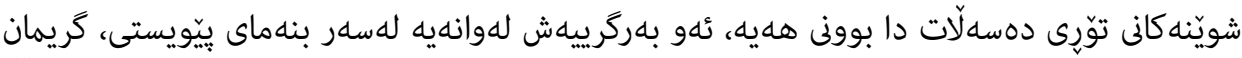

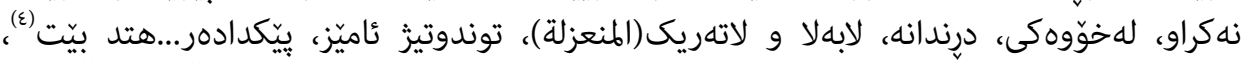

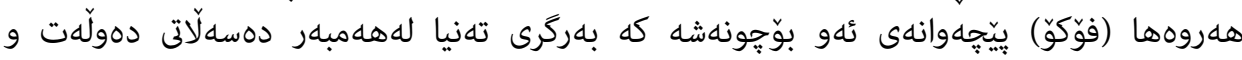

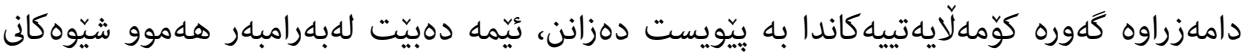

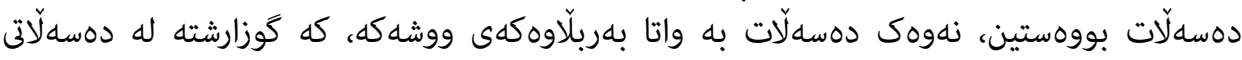

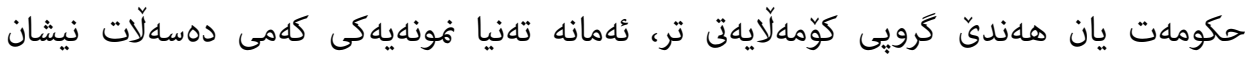

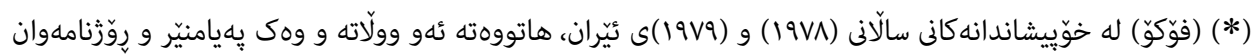

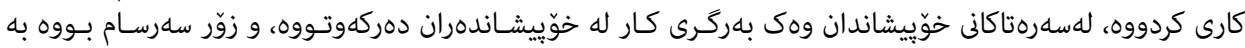

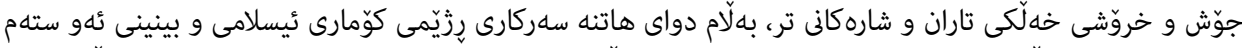

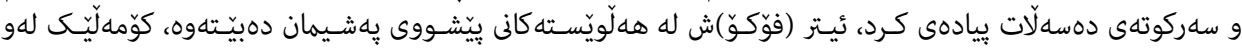

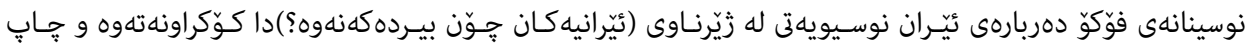

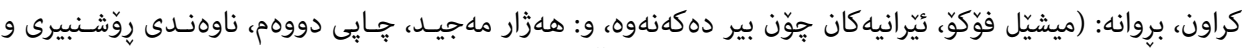

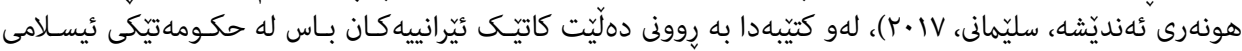

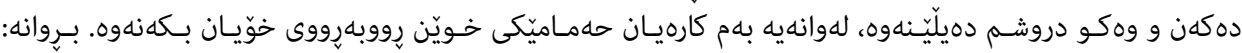

(هلمان سهرحهاوه، لاوع).

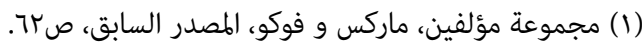

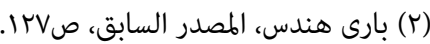

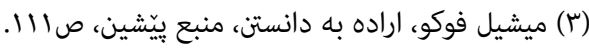

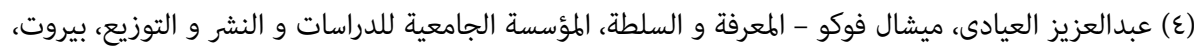

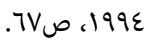




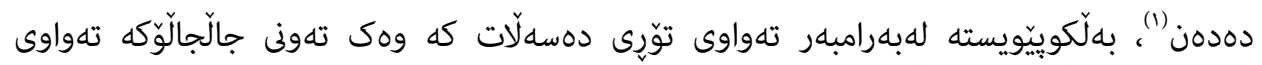

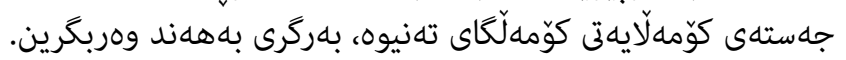

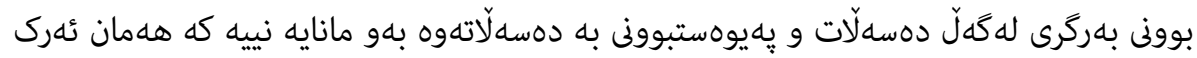

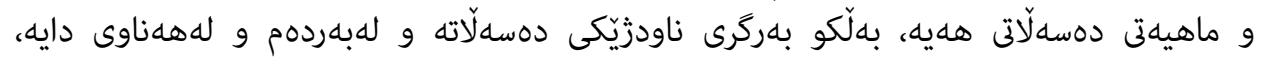

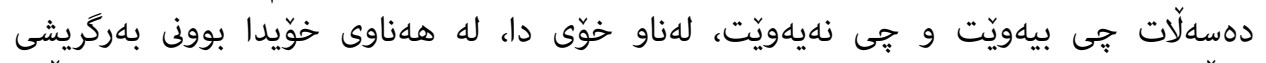

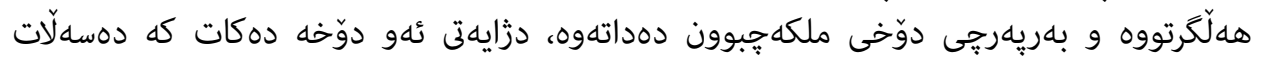

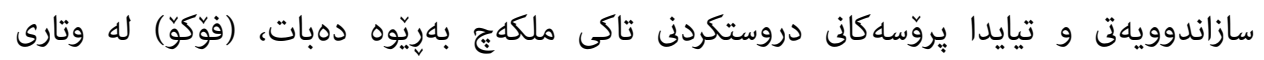

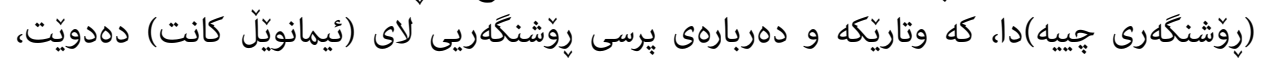

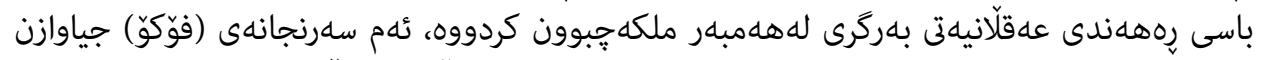

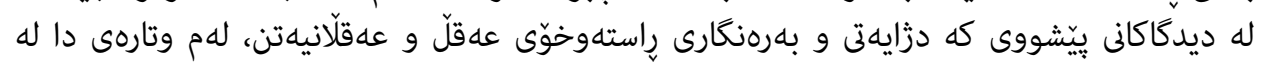

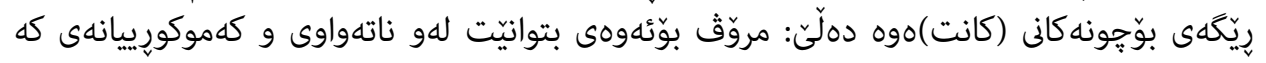

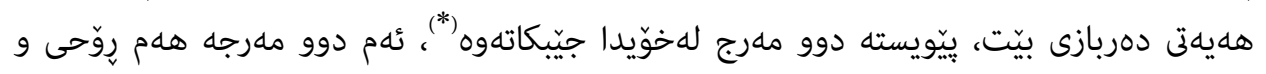

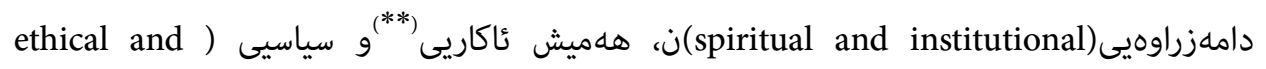
نolitical

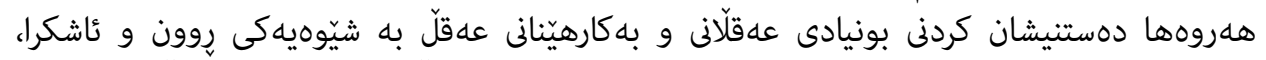

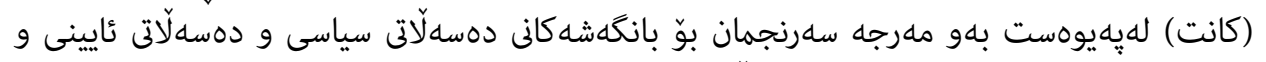

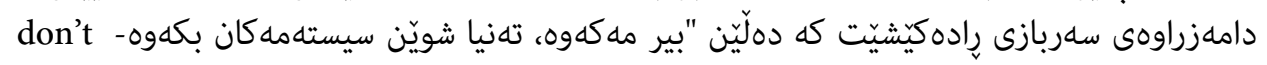
ناتوايَّ

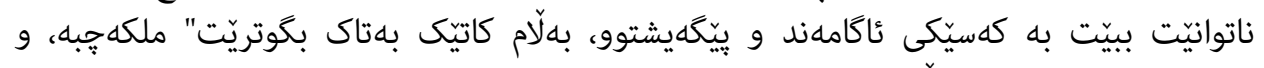

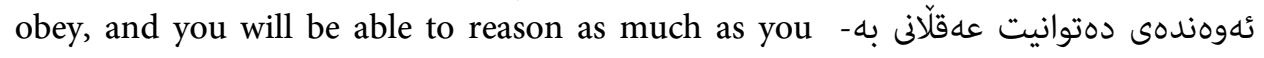

(1) Michel Foucault, Power- Moral Values- and the Intellectual (Interview with Michel Foucault), op.cit.

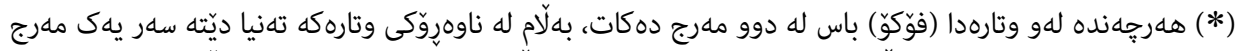

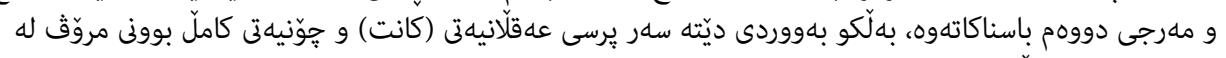

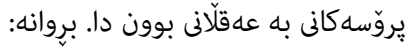
(Michel Foucault, readers, edited by: paul rabinow, pantheom books, new york,1984, pp35-50).

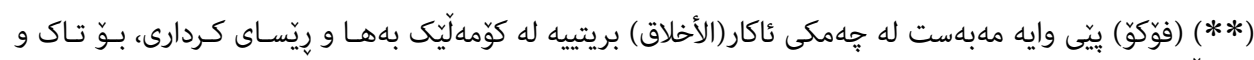

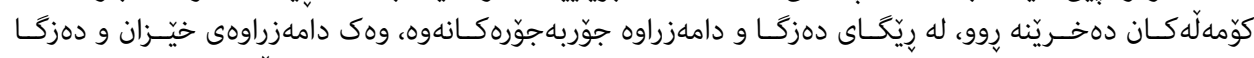

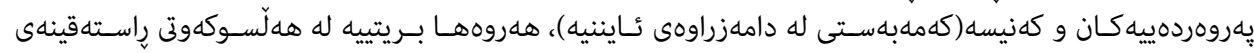

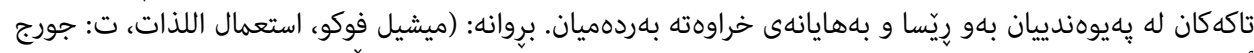

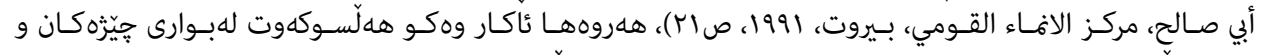

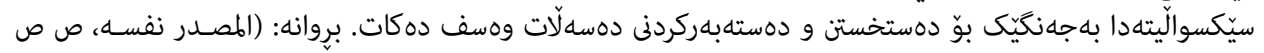




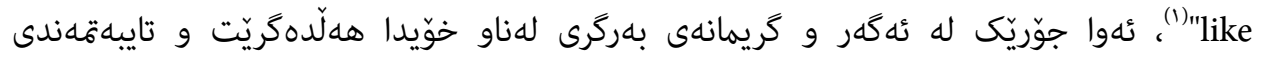

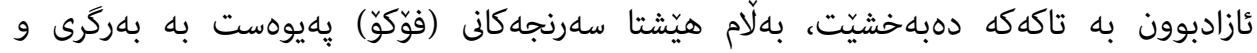

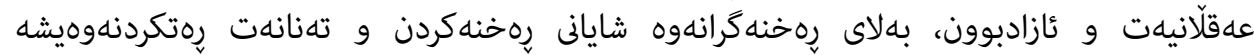

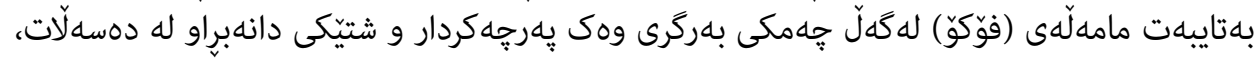

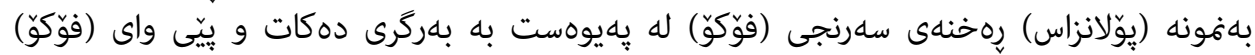

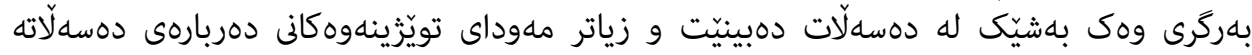

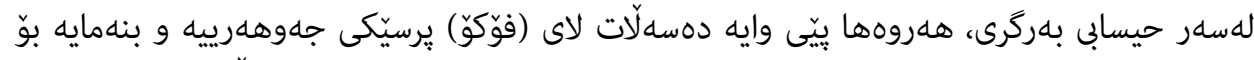

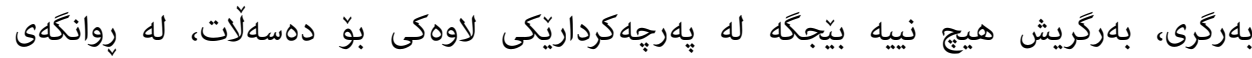

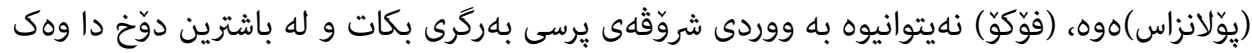

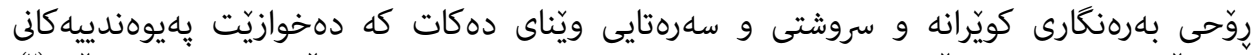

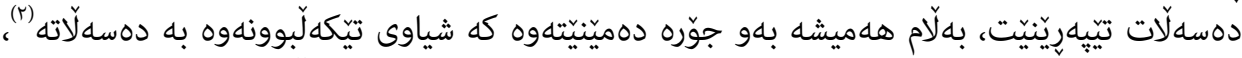

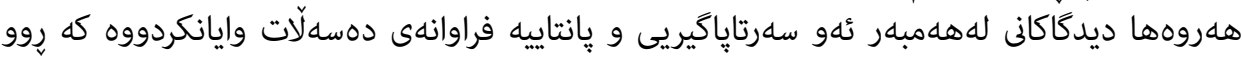

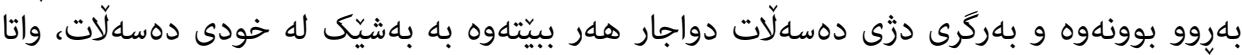

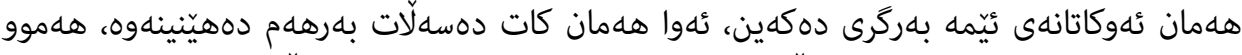

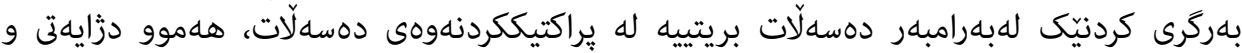

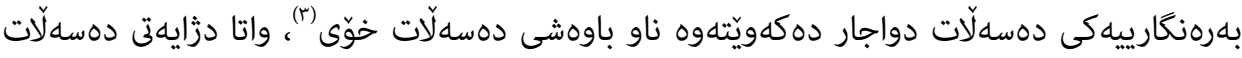

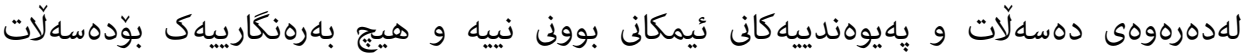

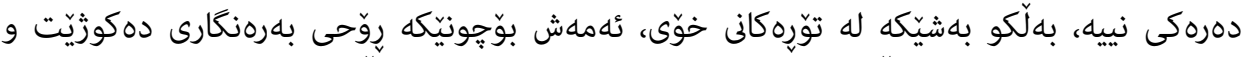

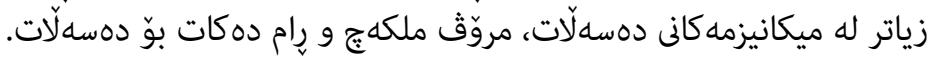

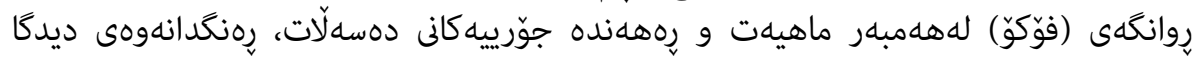

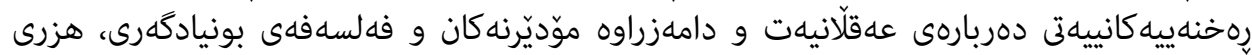

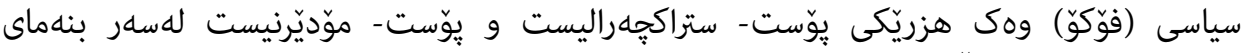

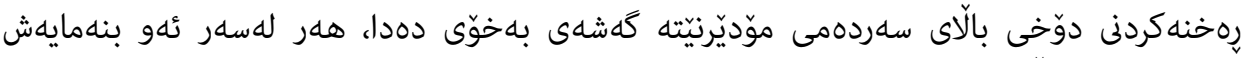

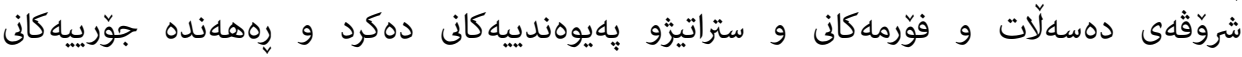

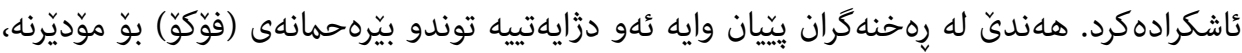

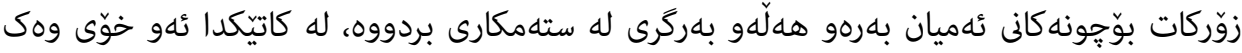

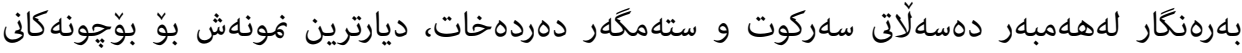

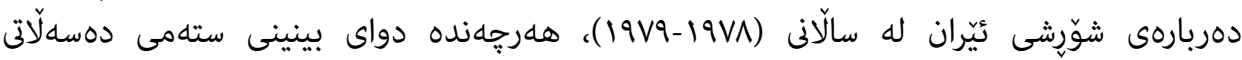

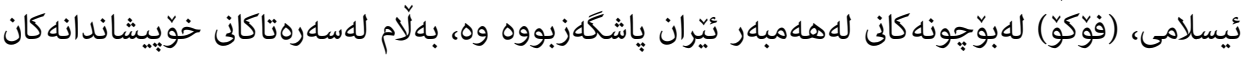

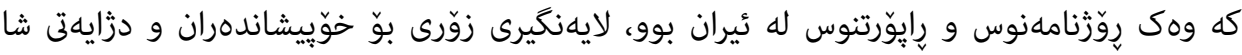

(1) Michel Foucault, readers, op.cit,pp35-36.

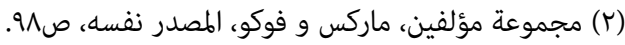

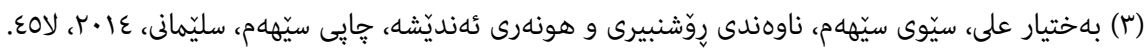


Janet Afary and - يَّوه دياربوو، دوو رِهنه كيسلامي (Kevin B. Anderson Foucault and the Iranian Revolution- Gender and the Seductions of - ئيسلامى (فؤن

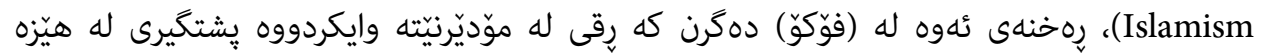

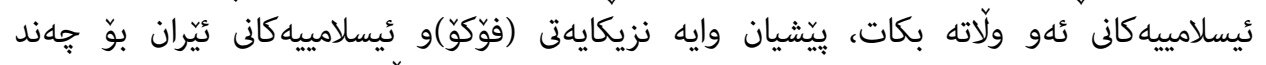

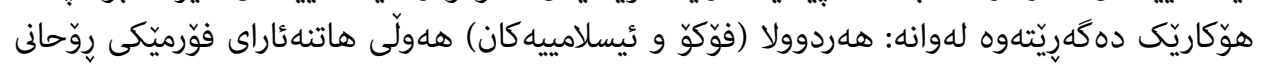

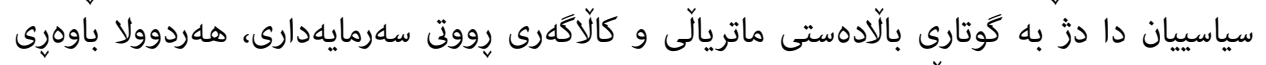

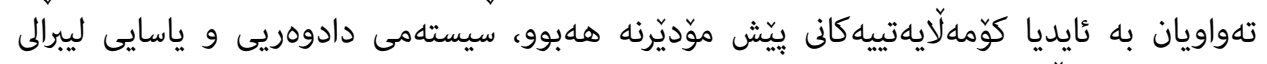

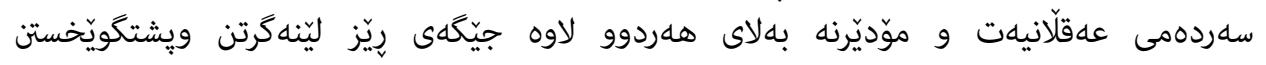
(ignore)

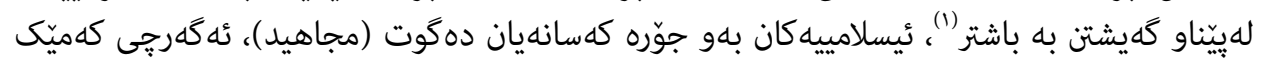

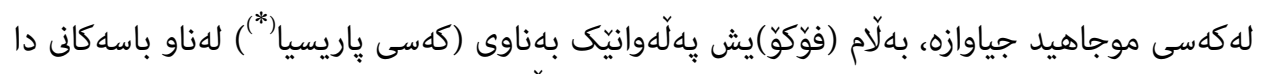

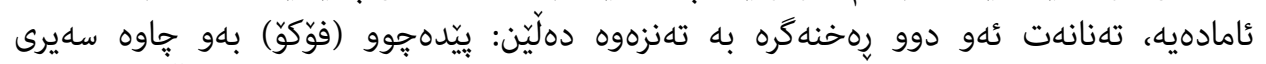

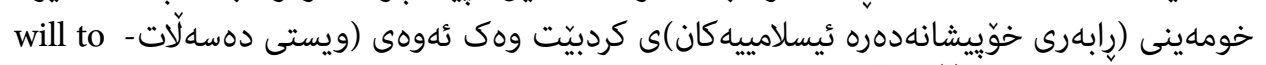
power

(1) Janet Afary and Kevin B. Anderson, Foucault and the Iranian Revolution- Gender and the Seductions of Islamism, The University of Chicago Press, Chicago and London, 2005, p13.

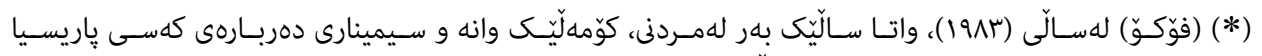

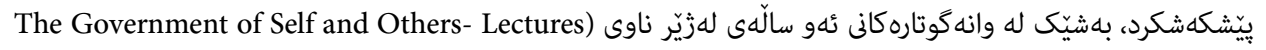

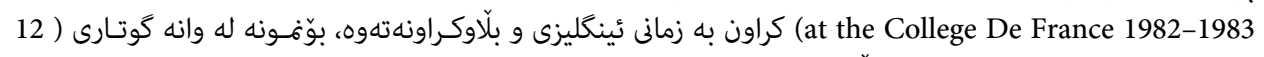
(January 1983: First hour

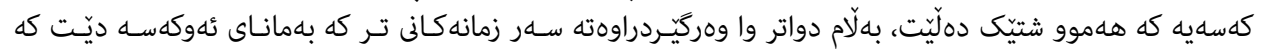

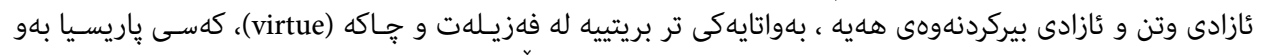

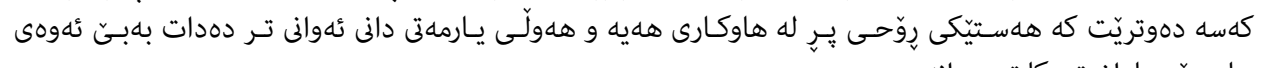

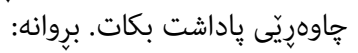
(Michel Foucault, The Government of Self and Others- Lectures at the College De France 19821983, Translated By Graham Burchell, Palgrave Macmillan, U.K, 2010, p43).

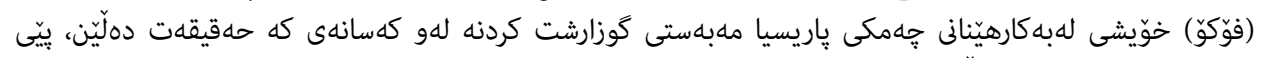

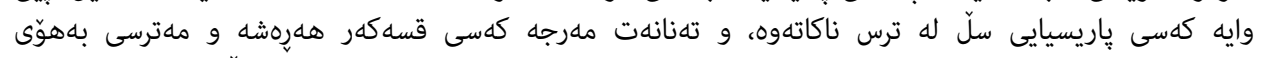

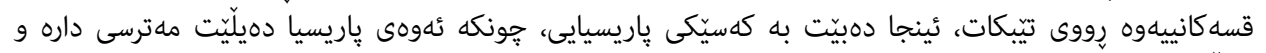

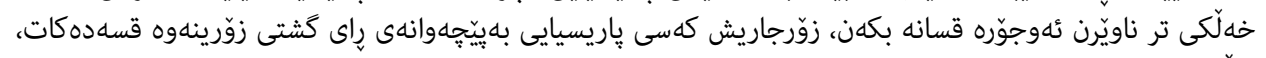

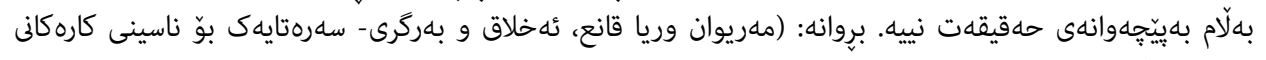

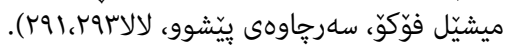

(2) Janet Afary and Kevin B. Anderson, op.cit, p14. 


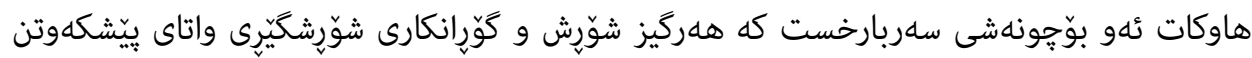

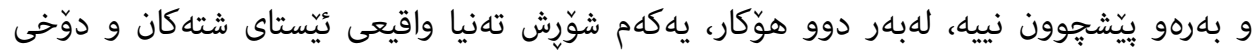

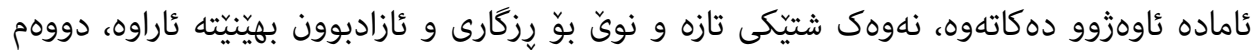

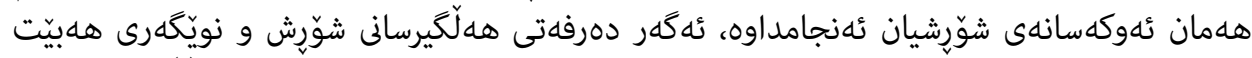

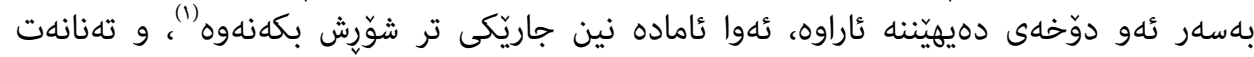

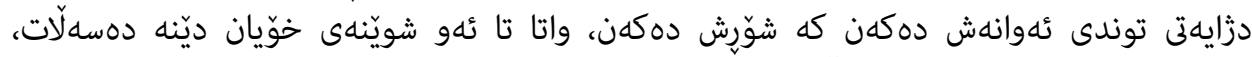

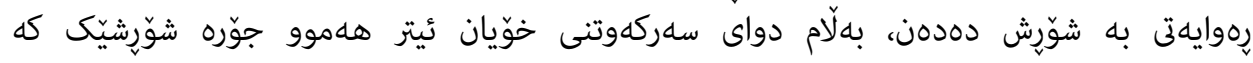

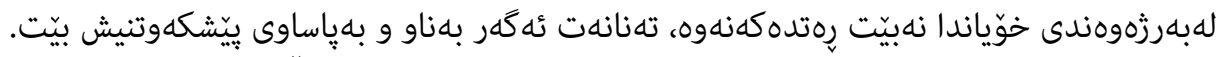

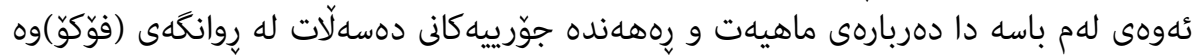

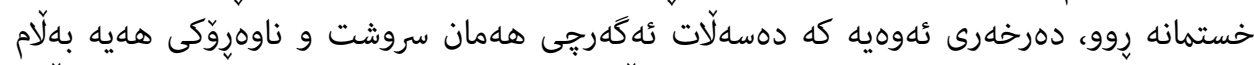

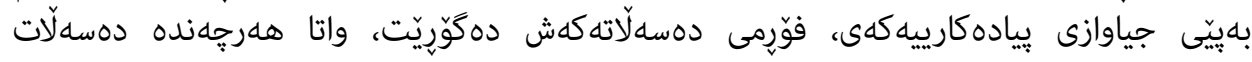

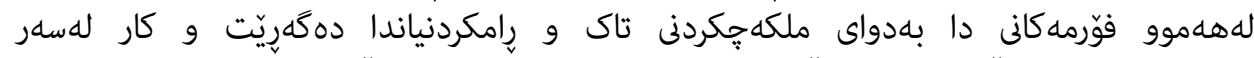

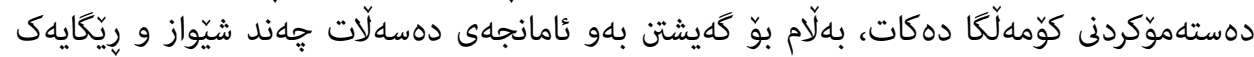

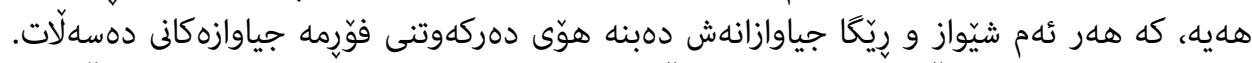

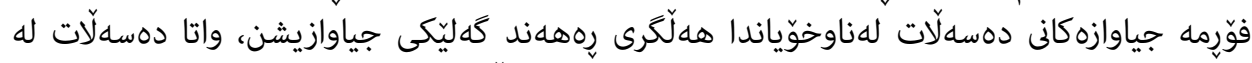

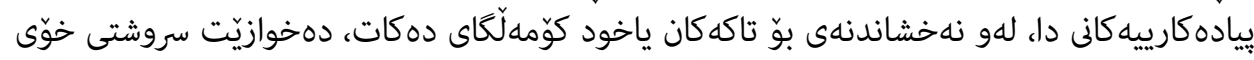

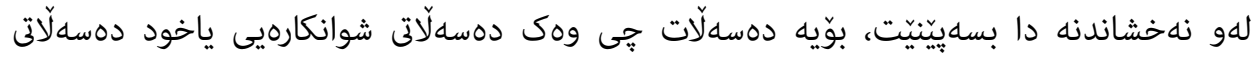

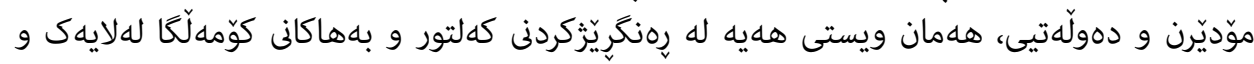

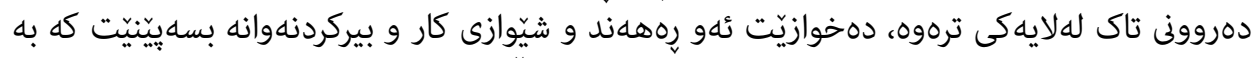

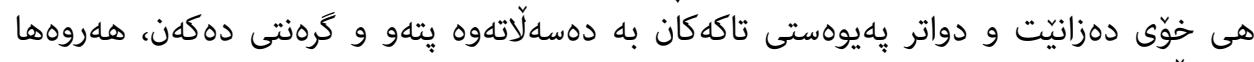

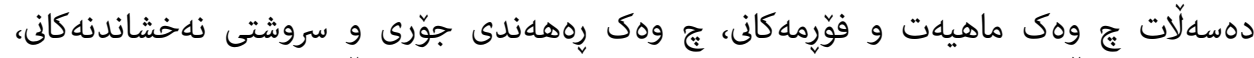

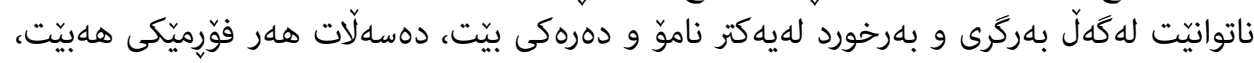

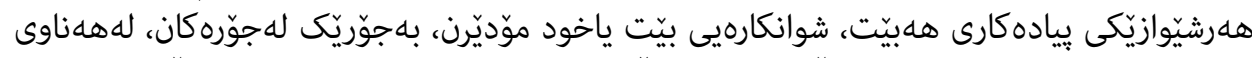

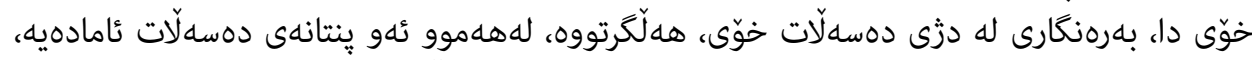

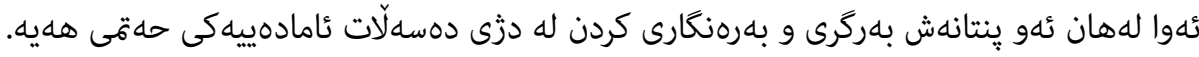

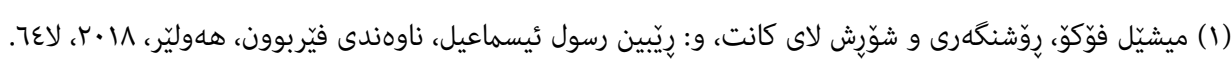




\section{كوّتايى و دهرئهذجام}

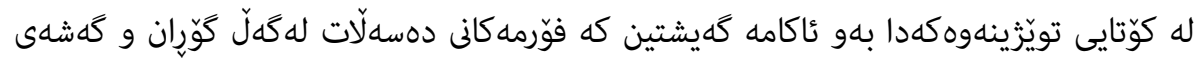

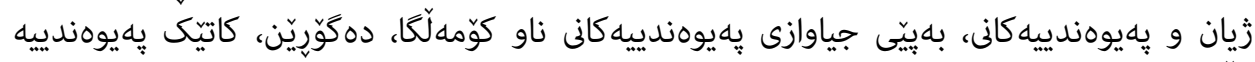

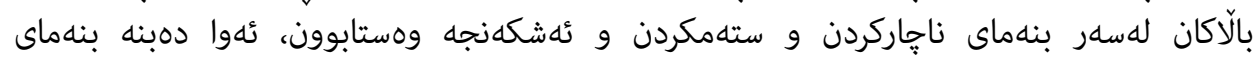

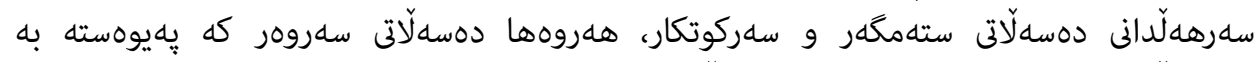

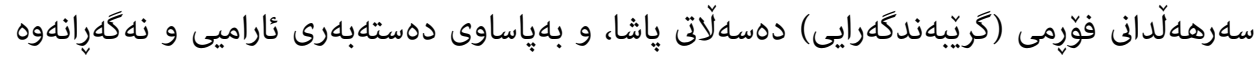

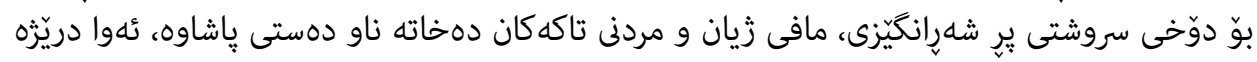

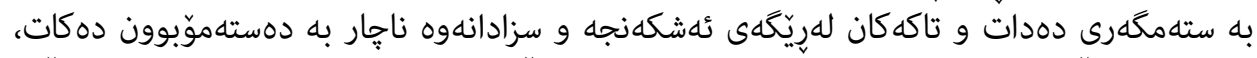

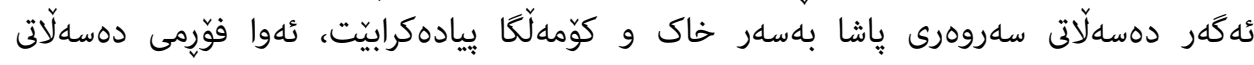

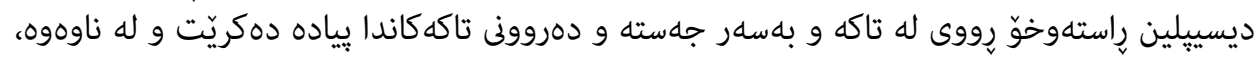

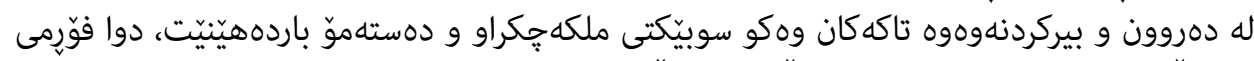

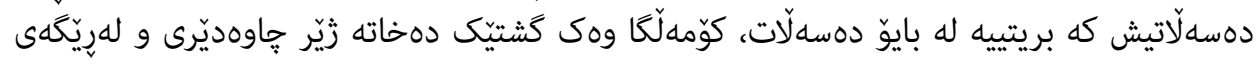

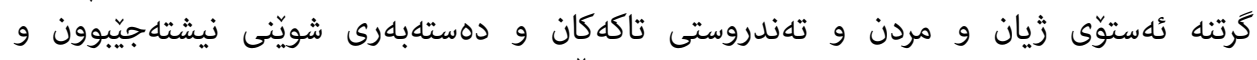

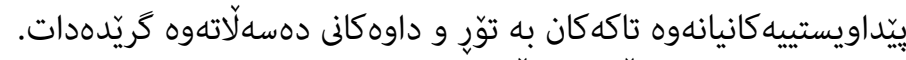

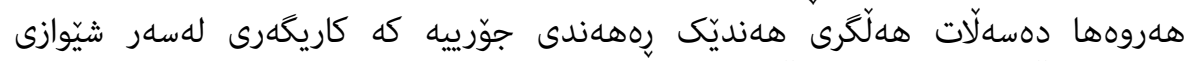

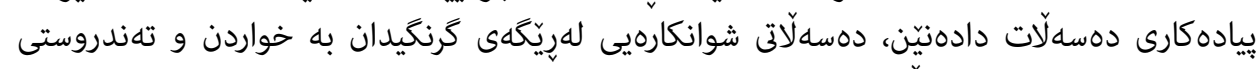

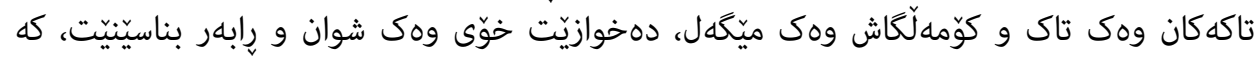

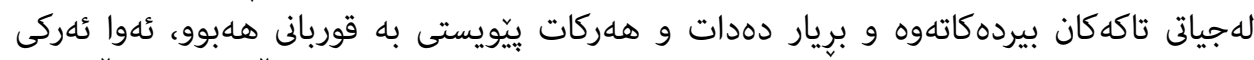

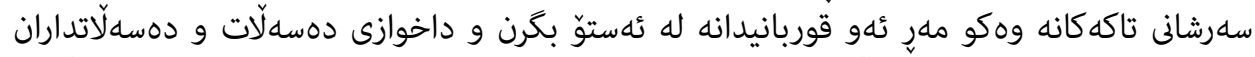

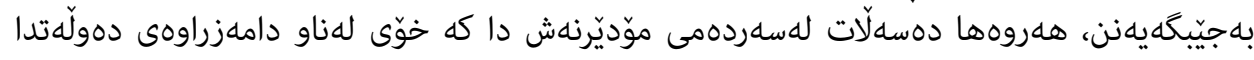

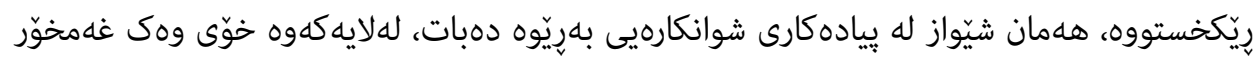

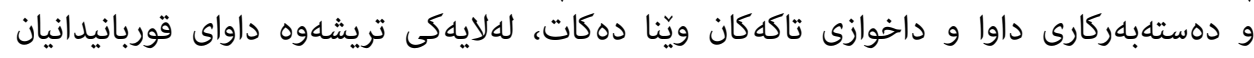

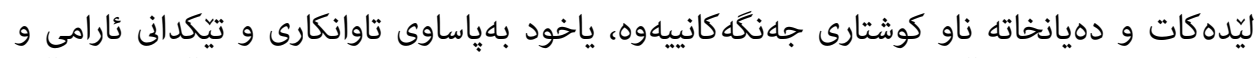

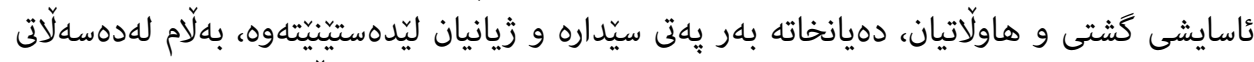

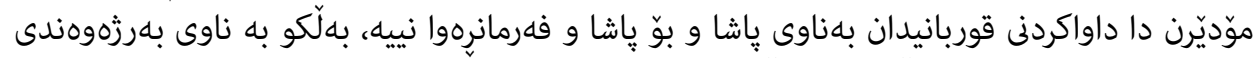

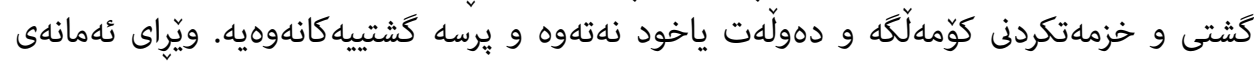

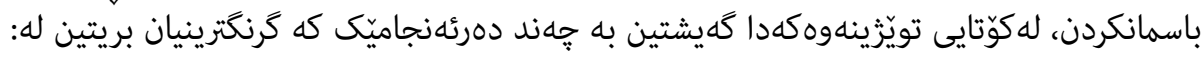

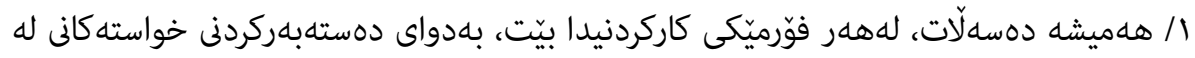

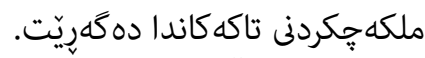

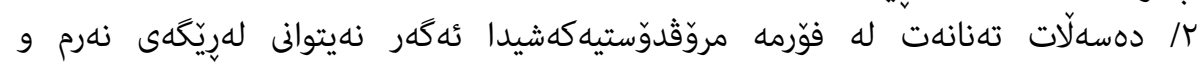

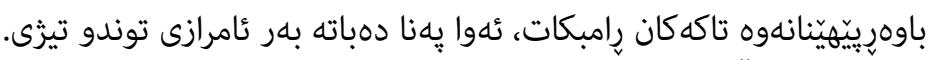

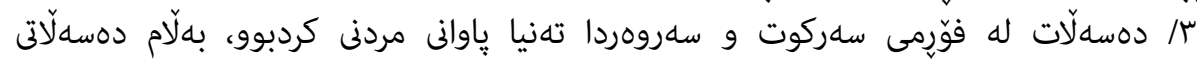


ديسييلين و تايبهتتر بايوّ دهسهلات ياوانى زيان و مردنيشيان بهيه كهوه كردووها

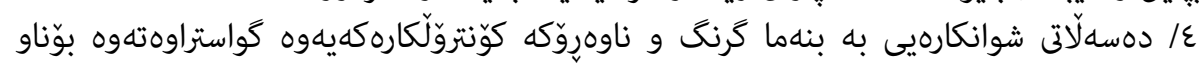

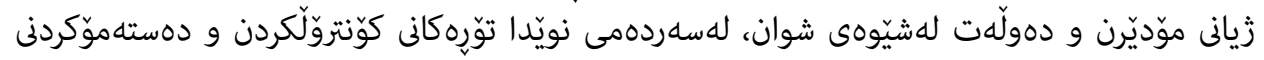
تاك بهريّوهدهبات.

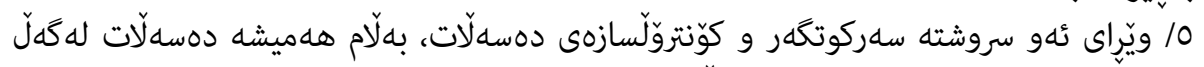

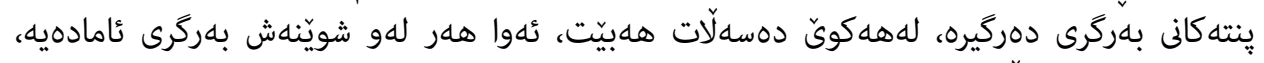

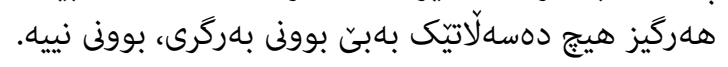




\section{ليستى سلهرجاوهكاز:}

\section{يه كهم/ كتيّب كتيّبى كوردى:}

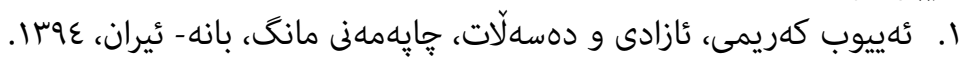

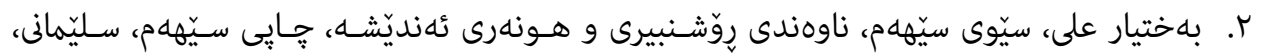

$r \cdot r \varepsilon$

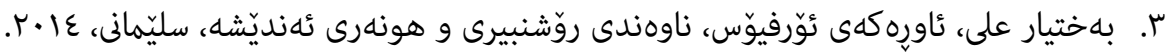

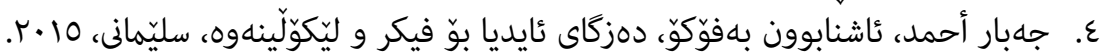

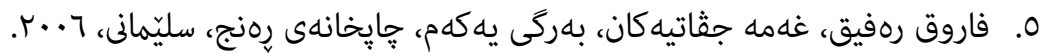

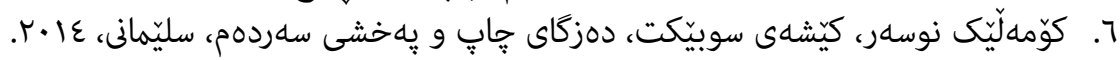

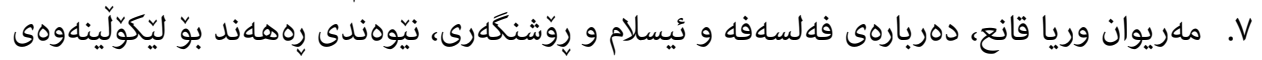

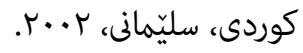

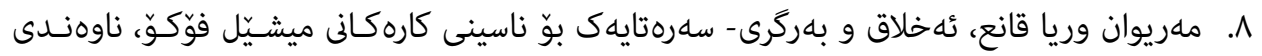

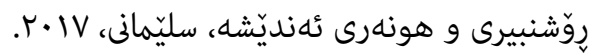

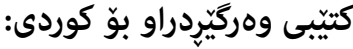

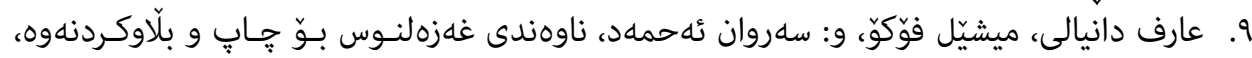

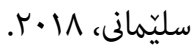

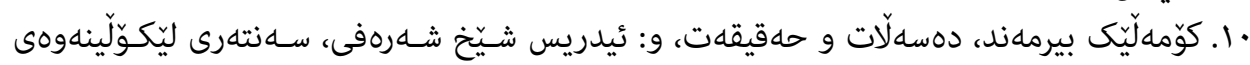

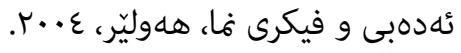

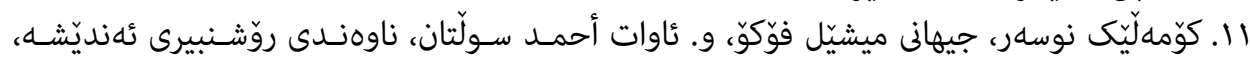

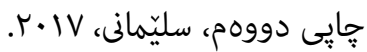

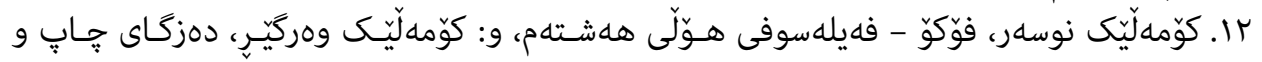

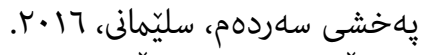

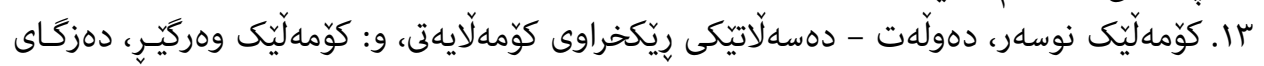

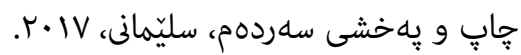

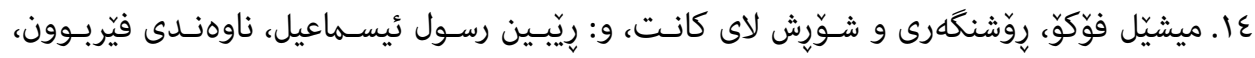

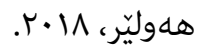

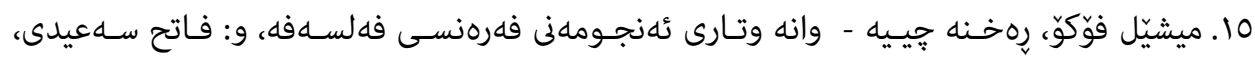

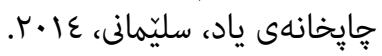

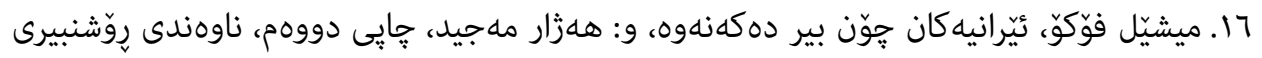




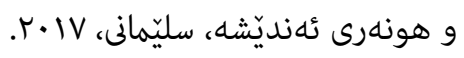

$$
\text { كتيّبى عهرهبى: }
$$

IV دولة خضر خنافر، فى الطغيان و الاستبداد و الدكتاتورية - بحث فلسفى فى مسألة السلطة الكلية،

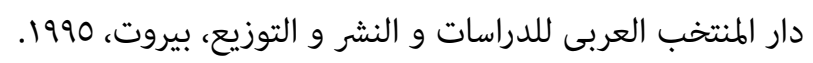

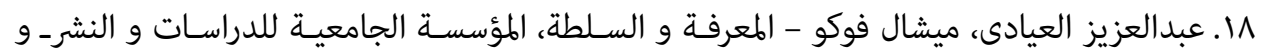

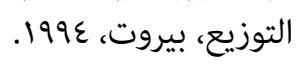

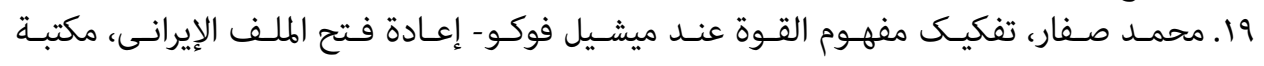

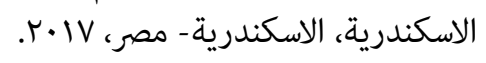

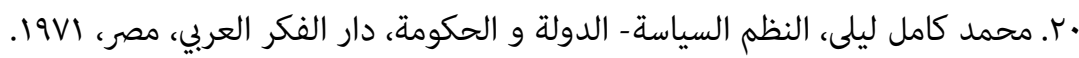

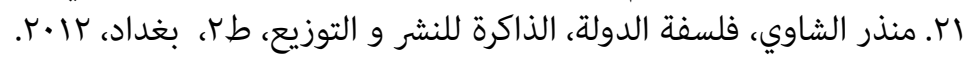

كتيّبى وهركَيِردراو بوّ عهرهبى:

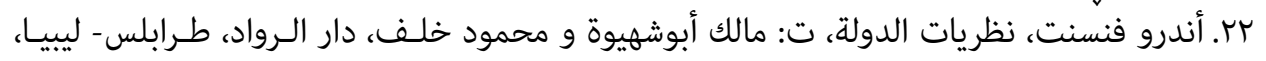

.199V

سبr. بيار كلاستر، مجتمع اللادولة، ت: محمد حسين دكروب، المؤسسة الجامعيـة للدراسـات و النشر-و و

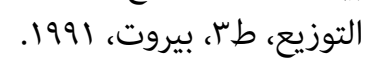

عَ. مجموعة مؤلفين، مـاركس و فوكـو، تيروت حسـن الحـاج، المؤسسـة الجامعيـة للدراسـات و النشر-و و

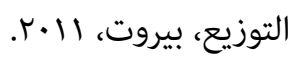

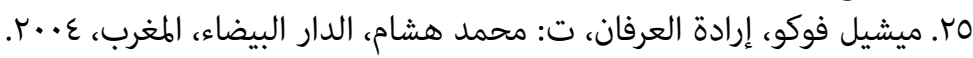

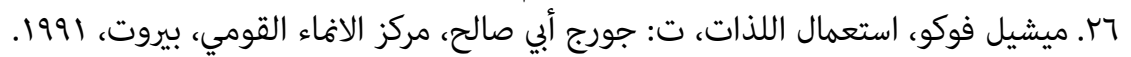

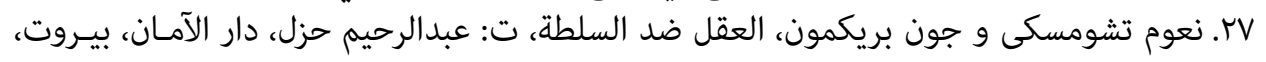
$r \cdot r \varepsilon$

$$
\text { كتيّبى فارسى: }
$$

r. محمد ضيمران، ميشل فوكو: دانش و قدرت، هرمس، تهران،

$$
\text { كتيّبى وهركِّردراو بوّ فارسى: }
$$

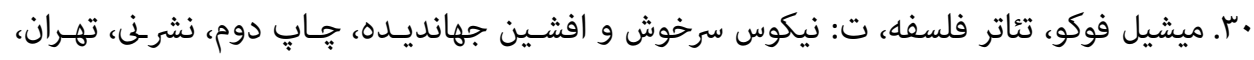

.

اس. ميشيل فوكو، اراده به دانستن، ت: نيكو سرخوش و افشين جهانديده، نشرنى، جاب ششـم، تهران،

$.1 \% 9$. 


\section{كتيّيى ئينكليزى:}

32. Alan Milchman and Alan Rosenberg Editors, Foucault and Heidegger - Critical Encounters, University of Minnesota Press, London, 2003.

33. Anthony Giddens, sociology- a brief but critical introduction, published by Macmillan education LTD, Second edition, London, 1986.

34. carl boggs, the tow revolutions(Gramsci and the dilemmas of western Marxism), south end press, U.S.A, 1984.

35. F.A.Hayek, The Road To Serfdom, Rutledge, London and New York, 2006.

36. Hubert L. Dreyfus and Paul Rabinow, Michel Foucault: beyond structuralism and hermeneutics, The University of Chicago, Chicago, 1983.

37. Janet Afary and Kevin B. Anderson, Foucault and the Iranian RevolutionGender and the Seductions of Islamism, The University of Chicago Press, Chicago and London, 2005.

38. Jose Guilherme Merquior, Foucault, University of California Press, U.S.A, 1985.

39. Lisa Downing, The Cambridge Introduction to Michel Foucault, CAMBRIDGE UNIVERSITY PRESS, New York, 2008.

40. Michel Foucault and Noam Chomsky, The Chomsky-Foucault Debate On Human Nature, The New Press, New York, 2006.

41. Michel Foucault, readers, edited by: paul rabinow, pantheom books, new york, 1984 .

42. Terry Eagleton, Why Marx Was Right, Yale University, London, 2011.

$$
\text { كتيّبى وهرگِّردراو بوّ ئينكليزى: }
$$

43. Jean Jacques Rousseau, The Social Contract- Or Principles Of Political Right, Translated by G. D. H. Cole, public domain, 2002.

44. Karl Marx and Frederick Engels, collected works- volume 5, translated by: W. Lough and C. P. Magill, published by Lawrence \& Wishart, London, 1938.

45. Michel Foucault Power and Knowledge- Selected Interviews and Other Writings 1972-1977, Translated by: Colin Gordon, Leo Marshall John Mepham and Kate Soper, Pantheon Books, New York, 1980.

46. Michel Foucault, critical inquiry- vol 8 - subject and power, translated from the French by: Leslie Sawyer, The University of Chicago Press, Chicago, 1982.

47. Michel Foucault, Discipline and Punish (The Birth of the Prison), Translated 
from the French by: Alan Sheridan, Vintage Books, New York, without date.

48. Michel Foucault, Society Must Be Defended- Lectures At The College De France 1975-1976, translated by: David Macey, published by Picador. New York, 2003.

49. Michel Foucault, The Government of Self and Others- Lectures at the College De France 1982-1983, Translated By Graham Burchell, Palgrave Macmillan, U.K, 2010.

50. Michel Foucault, the history of sexuality- vol 1, translated by: Robert Hurly, Pantheon Books, New York, 1978.

51. Michel Foucault, the order of things- an archeology of the human sciences, translation of les mots et les choses, pantheon books, new york, 1971.

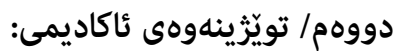

مر مرزوقى قورارية حليمة، الجسد و السلطة فى فلسفة ميشال فوكو، رسالة ماجستير غيــر منشـورة

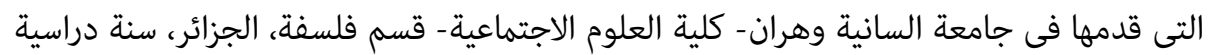

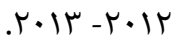

\section{سيّيهم/ ئينته رنيّت:}

53. Michel Foucault, Power- Moral Values- and the Intellectual (Interview with Michel Foucault - By: Michel Bess), Nov. 3, 1980, look this link:

https://www.michaelbess.org/foucault-interview/

54. Thirty Years' War, history, $3 \backslash 4 \backslash 2019$, look this link:

https://www.history.com/topics/reformation/thirty-years-war 